Portland State University

PDXScholar

Summer 9-8-2017

\title{
Constraining the Holocene Extent of the Northwest Meers Fault, Oklahoma Using High-Resolution Topography and Paleoseismic Trenching
}

Kristofer Tyler Hornsby

Portland State University

Follow this and additional works at: https://pdxscholar.library.pdx.edu/open_access_etds

Part of the Geology Commons, and the Geomorphology Commons Let us know how access to this document benefits you.

Recommended Citation

Hornsby, Kristofer Tyler, "Constraining the Holocene Extent of the Northwest Meers Fault, Oklahoma Using High-Resolution Topography and Paleoseismic Trenching" (2017). Dissertations and Theses. Paper 3890. https://doi.org/10.15760/etd.5778

This Thesis is brought to you for free and open access. It has been accepted for inclusion in Dissertations and Theses by an authorized administrator of PDXScholar. Please contact us if we can make this document more accessible: pdxscholar@pdx.edu. 
Constraining the Holocene Extent of the Northwest Meers Fault, Oklahoma Using High-Resolution Topography and Paleoseismic Trenching

\title{
by
}

Kristofer Tyler Hornsby

A thesis submitted in partial fulfillment of the requirements for the degree of

\author{
Master of Science \\ In \\ Geology
}

Thesis Committee:

Ashley R. Streig, Chair

Scott E.K. Bennett

Adam M. Booth

Portland State University

2017 


\begin{abstract}
The Meers Fault (Oklahoma) is one of few seismogenic structures with Holocene surface expression in the stable continental region of North America. Only the $\sim 37 \mathrm{~km}$ long southeastern section of the $\sim 55 \mathrm{~km}$ long Meers Fault is interpreted to be Holoceneactive. The $\sim 17 \mathrm{~km}$-long northwestern section is considered to be Quaternary-active (preHolocene); however, its low-relief geomorphic expression and anthropogenic alteration have presented difficulties in evaluating the fault length and style of Holocene deformation. We reevaluate surface expression and earthquake timing of the northwestern portion of the Meers Fault to improve fault characterization, earthquake rupture models, and seismic hazard evaluations based on fault length. We use a combination of airborne lidar (0.5-2 m-resolution), historical aerial photos, and new balloon-based photogrammetric (Structure from Motion) topography (0.25-0.5 mresolution) collected in this study to analyze and characterize the fault scarp and local fault zone geomorphology. In the northwest, complex surface deformation includes fault splays, a left step, subtle monoclinal warping, and a minor change in fault strike The fault is evident in the landscape as linear escarpments, incised channels on the up-thrown side of the scarp, and closed depressions on the downthrown side. I use topographic profiles, measured perpendicular to the fault scarp to show that the northwest scarp is characterized by decimeter surface offsets. Where the fault traverses the Post Oak Conglomerate the fault zone width rarely exceeds $25 \mathrm{~m}$, in the Hennessey Shale I document an increase in fault zone width with deformation occurring over $20 \mathrm{~m}$ to 115 m. I further examined the northwest section of the fault in a paleoseismic excavation
\end{abstract}


where weathered Permian Hennessey Shale and a 1-2 m-thick veneer of Holocene alluvial deposits have been folded and warped during three surface-folding earthquakes. In an adjacent stream exposure these units are also faulted near the ground surface. Paleoearthquake age modeling (Oxcal) constrained by accelerated mass spectrometry (AMS) dating of detrital charcoal and optically stimulated luminescence (OSL) dating of sandy alluvial beds indicates two earthquakes occurred since $6152-5550$ cal. years BP and one possibly older event along the erosional unconformity along the Hennessey Shale bedrock. This analysis lengthens the Holocene extent of the Meers Fault by 6 km, to $\sim 43 \mathrm{~km}$, and extends the paleoseismic record of the Meers Fault to 9598 cal. years BP. These data will improve fault-rupture and earthquake recurrence models used for seismic hazard analysis of the Meers Fault. 


\section{ACKNOWLEDGMENTS}

This research was supported by funding from the USGS National Earthquake Hazards Reduction Program (NEHRP, Award\# GISA00037), and a GSA Graduate Student Research Grant (2017). Rob Williams (USGS Geological Hazards Science Center) provided financial support for OSL age dating. This project was part of a collaboration between Portland State University, Oklahoma Geological Survey, and the United States Geological Survey.

I thank my advisor Ashley Streig for her guidance and support throughout this project as well my committee members Adam Booth and Scott Bennett for their patience, constructive feedback, and advice. Thanks to Ramon Arrowsmith for his expertise and assistance with Structure from Motion. Kenneth Cruikshank provided invaluable discussions regarding structural geology and fault mechanics and has been very supportive. I am very grateful for Shannon Mahan’s hard and thorough work processing and analyzing my OSL samples. Thanks to the following Oklahoma Geological survey and University of Oklahoma members; Jefferson Chang, Isaac Woefel, John Schwing, Noorulann Ghouse, and Shannon Dulin for their assistance and discussion in the field. I owe a special thanks to the property owners who granted me access to their land during field work; Tom Cavanaugh (Kimbell Ranch) and Dean Reeder's support, knowledge, and hospitality were critical to this thesis. Madeline Dillner and Richard Tarver from the Oklahoma Corporation Commission provided historical imagery and lidar datasets for this analysis and are greatly appreciated. 
I would like to thank my family and friends that have supported me throughout the duration of the project. I am also very grateful for the supportive and informative discussions that I have had with my fellow graduate students as well as my professors at Portland State University. 


\section{TABLE OF CONTENTS}

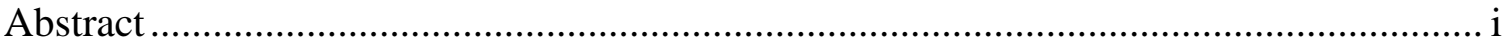

Acknowledgments..................................................................................................iii

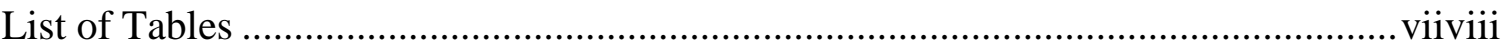

List of Figures ................................................................................................... ix

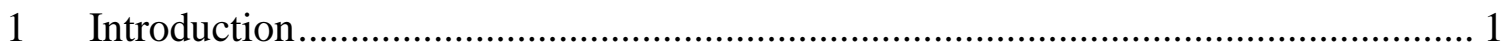

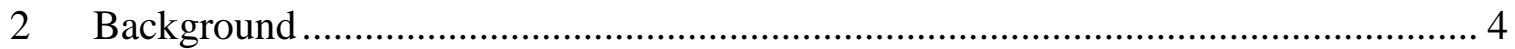

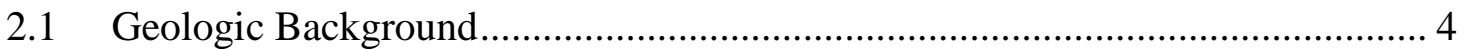

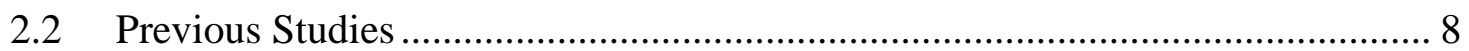

2.2.1 Geomorphic Mapping and Fault Length....................................................... 9

2.2.2 Paleoseismic Investigations and Earthquake Timing .................................. 9

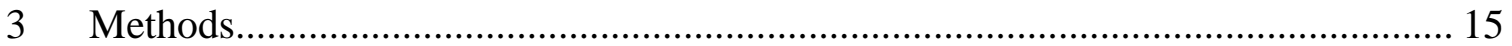

3.1 Fault Scarp Morphology Mapping ………………............................................ 15

3.1.1 Lidar Topography ………………………….................................. 15

3.1.2 Balloon-Based Photograph Topography and Structure from Motion ....... 17

3.1.3 Historical Aerial Photograph Topography.............................................. 29

3.1.4 Geologic and Geomorphic Mapping and Field Reconnasaince ................. 29

3.2 Water Moccasin Paleoseismic Site ................................................................... 30

3.2.1 Active Source Seismic Survey................................................................... 30 
3.2.2 Paleoseismic Trenching and Irrigation Ditch Mapping 31

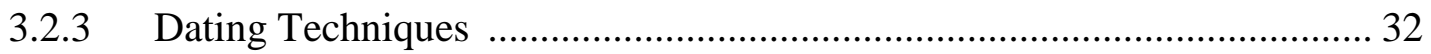

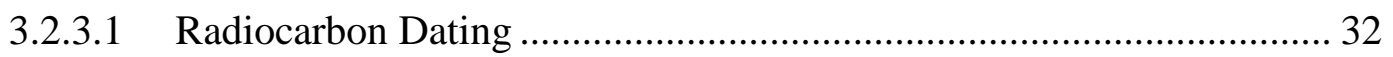

3.2.3.2 Optically Stimulated Luminescence (OSL) Dating ............................. 32

3.2.4 Oxcal Bayesian Statistical Age Modeling .............................................. 34

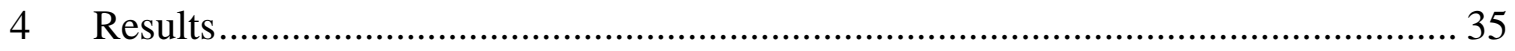

4.1 Fault Zone Morphology Mapping ................................................................ 35

4.1.1 Scarp Perpendicular Topographic Profiles ............................................ 36

4.1.2 Geologic and Geomorphic Field Mapping ......................................... 38

4.2 Water Moccasin Paleoseismic Site ................................................................. 44

4.2.1 Historic Irrigation Ditch Exposure .................................................. 44

4.2.2 Water Moccasin Paleoseismic Trench Location....................................... 45

4.2.3 Water Moccasin Trench Stratigraphy ................................................. 47

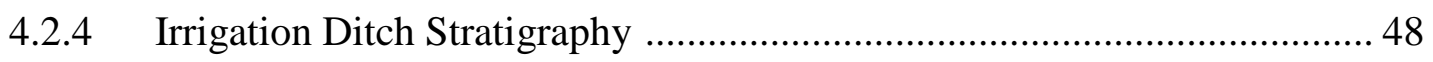

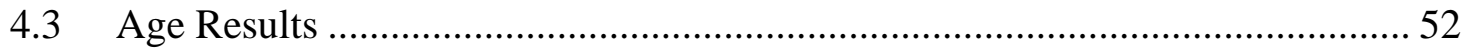

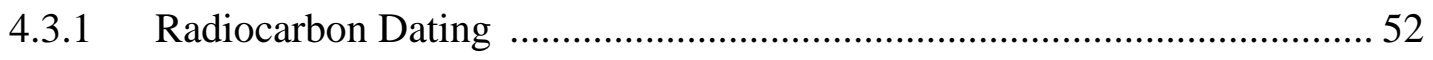

4.3.2 Optically Stimulated Luminescence (OSL) Dating ................................. 52

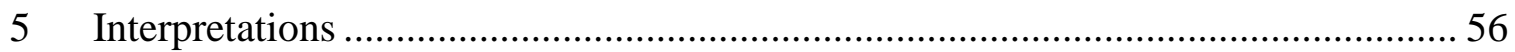




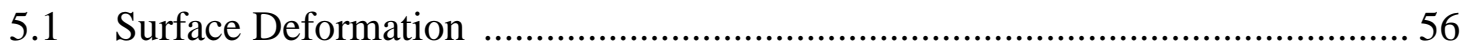

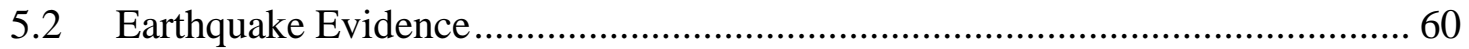

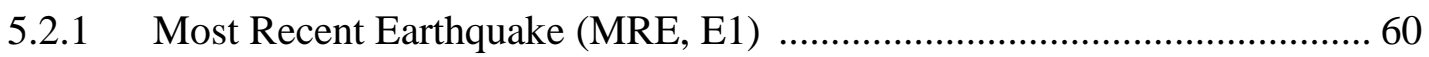

5.2.2 Penultimate Earthquake (E2) ………………......................................... 61

5.2.3 Ante-Penultimate Earthquake (E3) …………............................................. 62

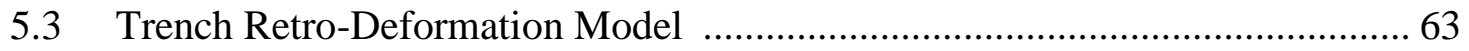

5.4 Earthquake Timing ....................................................................................... 68

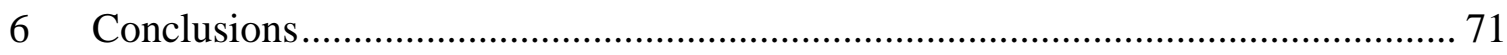

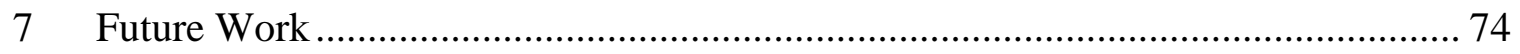

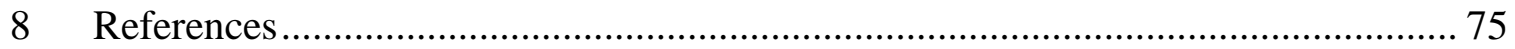

Appendix A: Additional Balloon-Based Structure from Motion and Lidar data.............. 80

Appendix B: Additional Topographic Profile Data .......................................................... 85

Appendix C: Paleoseismic Trench Detailed Unit Descriptions ........................................ 87

Appendix D: Additional Paleoseismic Site Orthomosaics .............................................. 89

Appendix E: Geophone Seismic Survey Data ................................................................ 91

Appendix F: Radiocarbon Sample Photographs .......................................................... 113 


\section{LIST OF TABLES}

Table 1. Balloon-Based Structure from Motion and Lidar Comparison and Statistics

Table 2. Radiocarbon Age Results

Table 3. Optically Stimulated Luminescence Results

Table 4. Topographic Profile Results

Table 5. Earthquake Evidence Summary

Table 6. Summary of OxCal Statistial Age Model Results 


\section{LIST OF FIGURES}

Figure 1. Overview Map of the Meers Fault and Study Area

Figure 2. Primary Structures in Southwestern Oklahoma

Figure 3. Fault Overview with lidar DEM derived hillshade and geology

Figure 4. Structure from Motion Processing Stages

Figure 5. Structure from Motion and lidar comparison

Figure 6. Lidar derivatives and fault strip map

Figure 7. Topographic profiles across the fault scarp

Figure 8. 1942 aerial photograph analysis

Figure 9. Plot of fault vertical separation along fault length

Figure 10. Site location map of the paleoseismic trench study area

Figure 11. Stratigraphic column of trench units

Figure 12. Water Moccasin trench west wall

Figure 13. Water Moccasin trench east wall

Figure 14. Relationship of vertical separation and width of deformation

Figure 15. Schematic event history (retro-deformation of stratigraphy)

Figure 16. OxCal bayesian statistical model of age results 


\section{Introduction}

The 55 km long Meers Fault in southwestern Oklahoma is one of the largest seismogenic structures in the Central and Eastern United States (CEUS), it is the only fault in Oklahoma with evidence for Holocene surface displacement, and poses a seismic hazard for the region (Baker and Holland, 2013). Uncertainty remains regarding the seismic hazard associated with the fault (Baker and Holland, 2013). Accurately defining the potential fault rupture length, estimating displacements, and improving the understanding of the earthquake recurrence interval are important input parameters for estimating the maximum earthquake magnitude capable of being produced by the Meers Fault. The fault is currently mapped into two, collinear sections (Figure 1), the southeastern $\sim 37 \mathrm{~km}$ long section is well defined and Holocene active (Crone and Luza, 1990; Kelson and Swan, 1990, Madole, 1988), whereas the northwestern 17 km long section is poorly mapped, lacks paleoseismic age constraints, and exhibits only discontinuous evidence for recent, surface deforming earthquakes due to its subdued geomorphic expression (Wheeler and Crone, 2001).

This thesis presents results from paleoseismic trenching coupled with highresolution age dating and modern topographic mapping along the northwest section of the Meers Fault. These data are used to revise the Holocene-active fault rupture length and the timing of Quaternary surface rupturing earthquakes. Recent studies have applied both Structure from Motion (SfM) and lidar to the imaging and characterization of active fault zones (Bemis et al., 2014; Johnson et al., 2014). This study also provides a case study of 
the effectiveness of SfM in a grassland intraplate environment where fault scarps have subdued geomorphic surface expression. I conducted geomorphic mapping using lidar

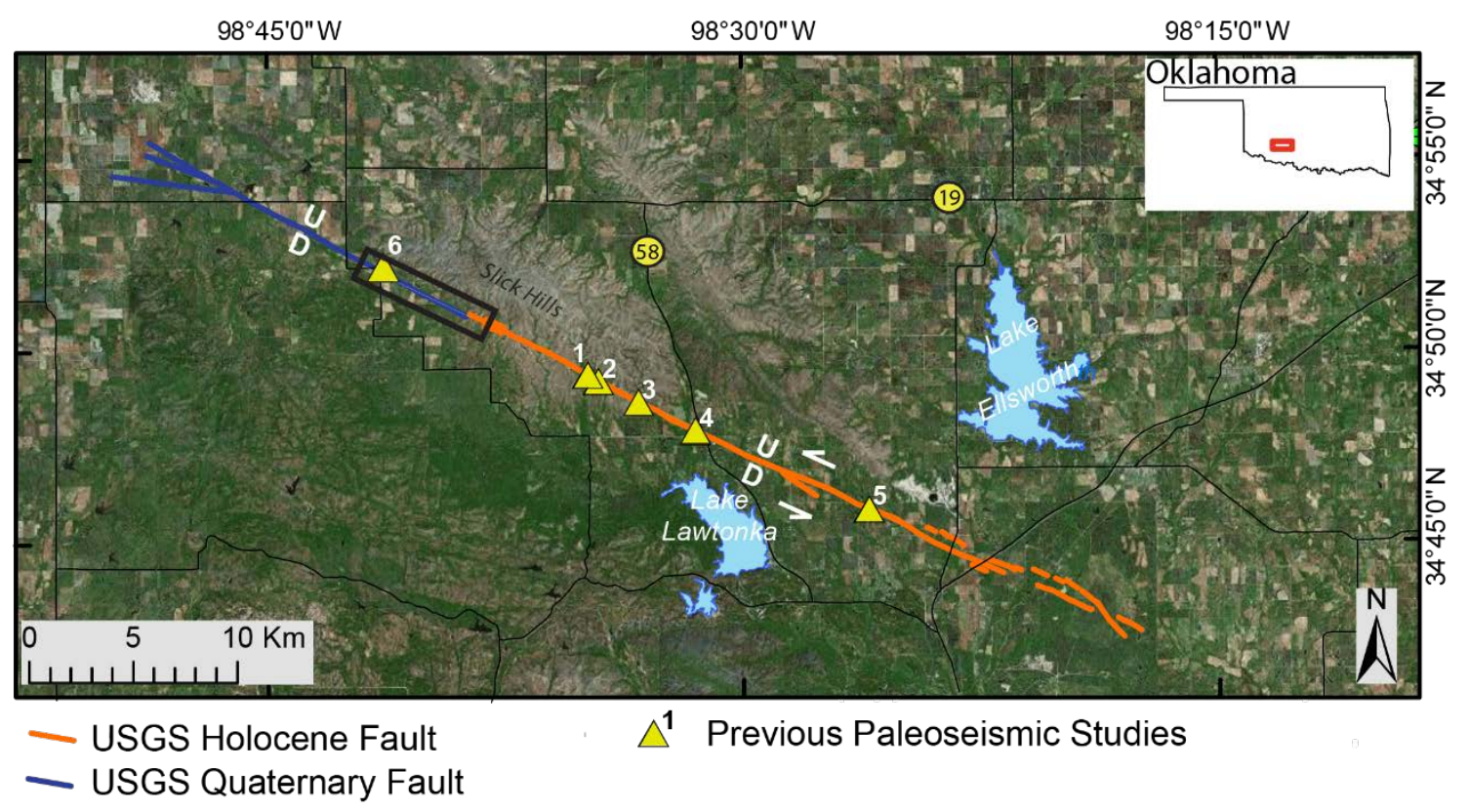

Figure 1. Overview map of the Meers Fault in southwest Oklahoma, as summarized by the U.S. Geological Survey (2006). The orange lines represent the currently mapped Holocene active trace of the fault and the blue line is the Quaternary (pre-Holocene) mapped section (Crone and Wheeler, 2000). The black rectangle is the lengthened Holocene-active trace presented in this analysis. Yellow triangles shown here and used in subsequent figures locate paleoseismic studies conducted in the late 1980's through early 1990's; 1) Valley Site, (Kelson and Swan, 1990); 2) Northwestern Ponded Alluvium (PA) Site, (Kelson and Swan, 1990); 3) PA and Southeastern PA sites, (Crone and Luza, 1990; Kelson and Swan, 1990) 4) Canyon Creek Site, (Luza et al., 1987; Crone and Luza, 1990; Kelson and Swan, 1990); 5) Browns Creek Site, (Madole, 1988); 6) Saddle Mountain Creek Sites, (Cetin, 1991; 1992).

and balloon-based SfM data and ground-truthed my mapped results during a field mapping campaign to select the location of a paleoseismic trench. Near the trench site, stream bank mapping was conducted where streams traverse the projected fault trace. An active-source geophone seismic survey was conducted at the paleoseismic trench site, prior to its excavation. I mapped stratigraphic units and deformation in the Water Moccasin trench site and collected samples from these units for two dating techniques: 
organic material for ${ }^{14} \mathrm{C}$ accelerated mass spectrometry (AMS) dating, and alluvial sands for optically stimulated luminescence (OSL). These age results were used to construct an OxCal Bayesian statistical age model to constrain the timing of surface deforming earthquakes at the site (after Lienkaemper and Bronk-Ramsey, 2009). The application of two different dating techniques that yield similar results improves confidence in the resulting age model.

In this thesis, I present a detailed description of the background geology, structural setting, and previous paleoseismic studies along the Meers Fault, followed by the methods used in field data collection and laboratory analysis. This section is followed by a summary and interpretation of my paleoseismologic results. I conclude this thesis with a summary of the study findings, implications for seismic hazard posed by the Meers Fault, and suggestions for future studies. 


\section{Background}

\subsection{Geologic Background}

The geology of southwest Oklahoma is dominated by the Southern Oklahoma Aulacogen (SOA), a failed rift zone, which trends WNW and includes the Wichita Mountains, Anadarko and Hardeman basins, and the Wichita Frontal Fault (WFF) system. The SOA formed during the late Proterozoic to early Cambrian and is a failed extensional arm of a plate tectonic triple junction (Burke, 1977). The opening of the Iapetus Ocean accompanied the breakup of the Rodinia supercontinent during the Neoproterozoic to Cambrian and created rift zones along the southern and eastern margins of Laurentia, the ancient North American craton (Hanson et al., 2011). The Southern Oklahoma rift zone, or aulacogen, extends deep into the continental crust at a high angle (Hanson et al., 2011; Hoffman et al., 1974), forming a long-lived, fault bounded trough. Extension in the Southern Oklahoma rift zone ceased in the late Mississippian, while rifting of the other two arms of the rift-rift-rift triple junction progressed to seafloor spreading (Gilbert, 1983; Hanson et al., 2011).

Igneous activity occurred in southwest Oklahoma during the late Precambrian and early Cambrian, and was concentrated during the pre-rifting and early rifting stages of the SOA (Browing and Hoppe, 1982; Gilbert, 1983; Keller and Baldridge, 2006). In the subsurface, felsic rocks of the Carleton Rhyolite Group are distributed parallel and elongate to the strike of the aulacogens bounding fault zones, indicating that they are related to extensional faults (Gilbert, 1983). The Wichita Mountains form the southern 
border of the Anadarko basin and are composed of a medium-grained alkali-feldspar granite. These felsic rocks may be the source of quartz grains used in OSL dating of trench sediments. The development of normal faults accompanied crustal extension and igneous activity, and likely provided deep crustal fractures forming the WFF system (Gilbert, 1983a).

Subsidence of the Anadarko basin and marine transgression followed this period of rifting (Hanson et al, 2013). The Anadarko basin is the deepest sedimentary basin in North America, with 12 to 15 kilometers of Cambrian to Permian sediments (Ham, 1964). Due to erosion and exhumation, Cambrian to Ordovician sedimentary units are exposed in the Slick Hills, north of the Meers Fault.

During the Pennsylvanian to early Permian, structural inversion of the SOA occurred as the region experienced compressional stress, forming the thrust-bounded Wichita Uplift (Ham, 1964; Perry, 1989). During the Wichita Uplift, reverse faulting, uplift, and syntectonic foreland sedimentation occurred as the region responded to the collision of Gondwana and the southern continental margin of late Paleozoic North America (Perry, 1989; Baker and Holland, 2013). Pre-existing weaknesses in the crust from earlier Precambrian to Cambrian rifting were reactivated as reverse or thrust faults in this compressional to transpressional stress regime (Hanson et al., 2013; Perry, 1989). The Ouachita orogenesis continued after thrusting of the Wichita Uplift ceased, as the Ouachita Mountains were thrust over the foreland basin. This sequence of tectonic events may have contributed to left-lateral wrench faulting observed in the Arbuckle and Wichita Mountains (Gilbert, 1983; Donovan, 1982). 
The WFF forms the boundary between the Wichita-Amarillo uplift to the southwest and the Anadarko-Ardmore sedimentary basin to the northeast (Figure 2). Major faults of the WFF include the Meers, Mountain View, Blue Creek Canyon, Clement, Cordell, and Duncan-Criner fault systems (Figure 2; Gilbert, 1983; Ham, 1964; Crone and Luza, 1990). The WFF continues for nearly $175 \mathrm{~km}$, from southern Oklahoma into the panhandle of Texas. Geophysical studies and deep borehole drilling for petroleum exploration provide evidence of at least 12 kilometers of cumulative throw along the WFF, between the Wichita-Amarillo Uplift and the base of the Anadarko basin (Ham and Wilson, 1962). 


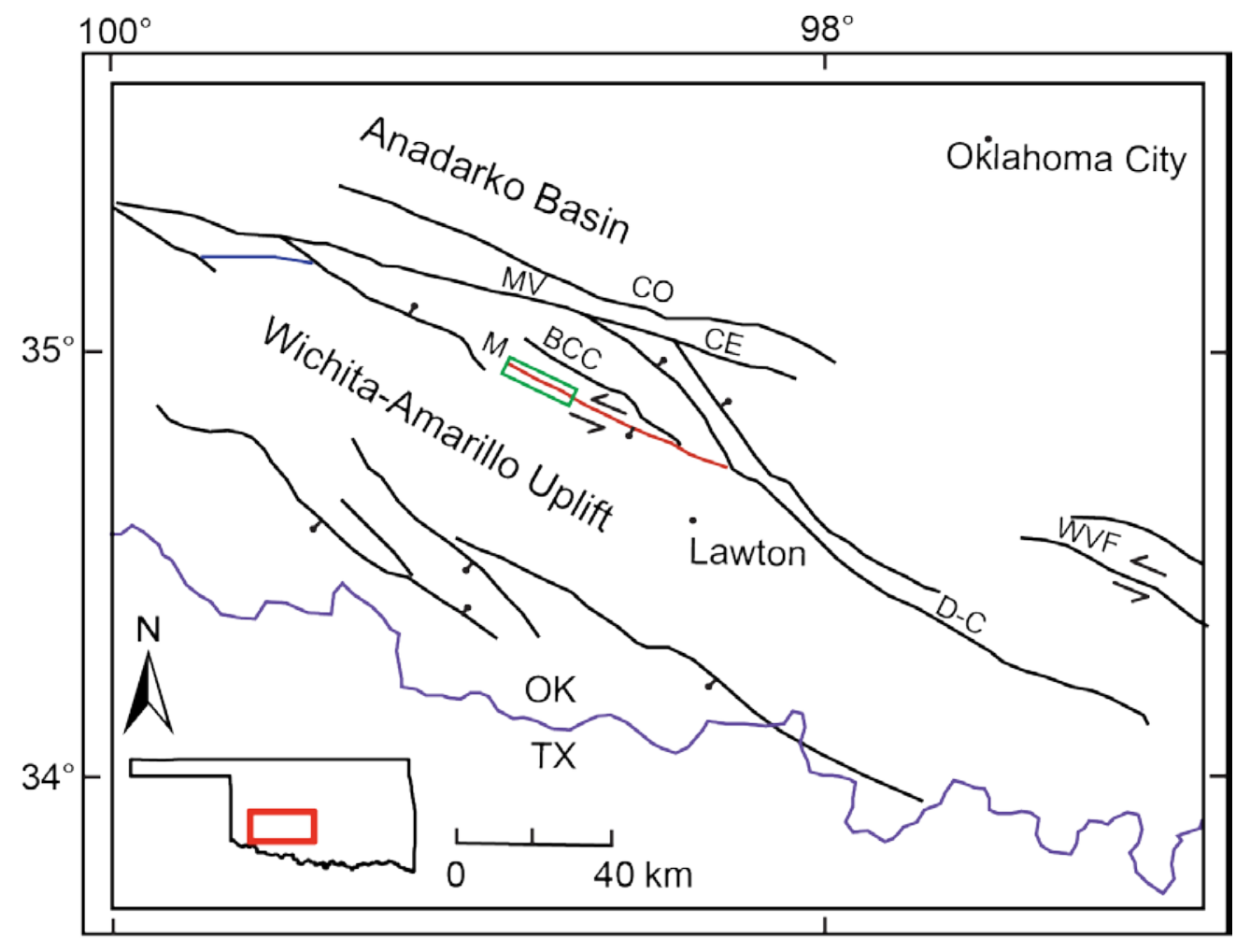

Study Area $\perp$ Fault (Bar indicates downthrown side)

Figure 2. Primary structures in southwestern Oklahoma are shown in black including; the Anadarko Basin, bounding faults, and the Wichita-Amarillo Uplift. The Wichita Frontal Fault (WFF) system separates the Wichita-Amarillo Uplift from the Anadarko Basin. The Meers Fault is shown as a red line. The northwest Meers Fault study area is shown by the green rectangle. Major faults in the system include: Meers, M; Blue Creek Canyon, BBC; Mountain View, MV; Clement, CE; Cordell, CO; and Duncan-Criner, D-C. The Oklahoma -Texas border is shown by the purple line. Modified from Crone and Luza, (1990).

The $\mathrm{N} 60^{\circ} \mathrm{W}$ trending Meers Fault is very linear and cuts across topography along the mapped southeast section (Figure 3A) indicating that the fault plane must be near vertical (Crone and Luza, 1990). Although the Meers Fault lacks historical seismicity, it exhibits a prominent down-to-the-southwest geomorphic expression and offsets Holocene deposits, indicating late Quaternary slip rates greater than erosion or denudation rates (Kelson and Swan, 1990). Along its length, the fault cuts two Permian bedrock units at the surface, the Post Oak Conglomerate and the Hennessey Shale (Figure 3B; Crone and 
Luza, 1990). The Post Oak Conglomerate is a well indurated, limestone-pebble conglomerate within a limestone matrix, and is relatively resistant, forming prominent southwest-facing bedrock scarps. The Hennessey shale is relatively less resistant and forms fault scarps that are relatively more rounded, with low-relief geomorphic surface expression. Paleoseismic investigations along the Meers Fault have shown that the Hennessey Shale accommodates deformation distributed over a zone that is tens to hundreds of meters wide, and locally exhibits folding of the surface (Kelson and Swan, 1990; Crone and Luza, 1990). In regions lacking bedrock exposure, Permian units are unconformably overlain by Quaternary alluvium units. The southeastern $\sim 37 \mathrm{~km}$ of the Meers Fault traverse Quaternary alluvial stratigraphy and forms linear escarpments across these surfaces. However, the youngest mapped alluvial unit, the East Cache alluvium ( 800 - 100 yrs. BP) does not show vertical separation along the fault trace (Madole, 1988).

\subsection{Previous Studies}

The Meers Fault was first mapped by Harlton (1951) and was initially named the Thomas Fault. Moody and Hill (1956) first determined that the Meers Fault was a Quaternary active fault based on the observation of a scarp crossing Quaternary alluvium. During the 1980's, researchers excavated several paleoseismic trenches across the fault scarp and documented evidence of late Holocene surface rupturing earthquakes along the southeast section of the Meers Fault (Crone and Luza, 1990; Madole, 1988; Kelson and Swan, 1990). 


\subsubsection{Geomorphic Mapping and Fault Length}

The southeast section of the Meers Fault is well pronounced and visible in both aerial and satellite imagery, and was initially mapped as a 26-kilometer-long linear escarpment with down-to-the-south vertical displacement by Gilbert (1983a). Holocene geomorphic expression, was lengthened to 37 kilometers (Figure 1) using low-sun aerial photographic mapping (Ramelli and Slemmons, 1987). Cetin (1991), inferred that the Holocene-active trace of the Meers Fault was 55 km long, lengthening the fault an additional $\sim 17 \mathrm{~km}$ to the northwest (Figure 1). This was based on geomorphic mapping of offset fluvial terraces, deflected drainages, and stream bank exposures of bedrock and alluvium with apparent vertical separation projecting toward the fault (Cetin, 1991). Due to a lack of quantitative age results of offset stratigraphy as well as inferred lateral displacements that may be explained by the natural sinuosity of meandering streams, this 17 km section has lacked evidence for Holocene surface rupturing earthquakes (Crone and Wheeler, 2001).

\subsubsection{Paleoseismic Investigations and Earthquake Timing}

\section{Southeast Meers Fault}

Madole (1988) conducted the first study documenting Holocene displacements on the Meers Fault, at two sites on the southeastern section, in Canyon Creek and Brown's Creek (Figure 1). Madole interpreted that the youngest faulted unit was the Brown's Creek Alluvium ( 14,000-9,800 yrs. BP) and that the East Cache Alluvium ( 800-100 yrs BP) and younger deposits are not faulted (Madole, 1988). Radiometric soil humic 
C14 ages were calibrated for their mean residence time with radiometric dates from detrital charcoal fragments collected from the Brown's Creek Alluvium, fault-derived alluvium, and unfaulted younger East Cache Alluvium. Madole concluded that the most recent surface faulting earthquake occurred on the Meers Fault between 1,400-1,100 yrs. B.P. (charcoal age of $1280 \pm 140$ B.P.), and that folding accounted for at least as much vertical displacement as brittle faulting (Madole, 1988). Madole also mapped shallow stream incision on the up-thrown side of the fault and thickened slopewash deposits on the downthrown side, indicating erosion of the fault scarp and deposition below the scarp (Madole, 1988).

Several trenches were excavated along the southeastern Meers Fault to document the style and timing of Holocene displacement along the fault by Crone and Luza (1987;1990). They excavated two trenches (Canyon Creek 1 and 2) east of the Slick Hills (Figure 1), where Permian Hennessey shale bedrock is overlain by Quaternary alluvial deposits. Here, where the fault traverses the highly weathered Hennessey Shale, they determined that monoclinal warping was the primary style of surface deformation. They concluded that nearly three meters of vertical throw occurred during a single event, with "plastic" deformation within the Hennessey Shale, which made lateral movement difficult to quantify (Crone and Luza, 1990). Herein we will describe the style of deformation as broad-distributed deformation or monoclonal fold deformation.

A second trench (SE ponded alluvium site) was excavated farther west, across a topographically sharp fault scarp in the Slick Hills (labeled as site 4 Figure 1), where brittle surface faults cut Post Oak Conglomerate bedrock in the trench exposure. In the 
Slick Hills, fault scarps in well-lithified and resistant Permian conglomerate are 2-3 times higher than scarps in Quaternary alluvium deposits in adjacent erosional fluvial valleys (Crone and Luza, 1990). Crone and Luza (1990) documented complex surface deformation along the Meers Fault and showed that the style of surface deformation may be a function of lithology, variations in displacement along the length of the fault, and the presence of multiple fault splays (Crone and Luza, 1990).

The most recent paleoseismic study of the Meers Fault was conducted by Kelson and Swan (1990), at two sites (the NE and SW Ponded Alluvium Sites) within the Slick Hills (labeled as sites 2 and 3 on Figure 1), where the Post-Oak Conglomerate bedrock is overlain by a veneer of interfingering alluvial and colluvial deposits. They also excavated a trench at the Canyon Creek site (labeled as site 4 on Figure 1) across the Hennessey Shale bedrock. They found evidence of two surface rupturing earthquakes within the last $\sim 3400$ years. Their penultimate event is constrained between $\sim 2900-3400$ yrs. BP, and the most recent earthquake (MRE) having ruptured 1050 yrs. BP (Kelson and Swan, 1990). They also concluded that surface deformation is accommodated by both faulting and folding, and that the style of deformation varies greatly along the length of the Meers Fault.

Kelson and Swan (1990) dug numerous small trenches at two of the paleoseismic sites in their study (Figure 1; sites 2 and 3). These trenches were oriented sub-parallel and orthogonal to the fault scarp to evaluate both lateral and vertical components of Holocene displacement (Kelson and Swan, 1990). At these two sites, they identified offset buried channels on the north and south sides of the fault. The buried channel 
deposits were used as piercing points to estimate left-lateral displacements, which ranged from $3.0 \pm 1.1 \mathrm{~m}$ and $3.7 \pm 1 \mathrm{~m}$ (Kelson and Swan, 1990). Uncertainty in the measured displacement is due to variations in channel thickness as well as piercing point determination. They also identified two scarp-derived colluvial units at these sites, interpreting them as evidence for two surface rupturing earthquakes. Radiometric analysis of soil humus, using an estimated average mean residence time (AMRT) for soil from these sites agree with age results from previous paleoseismic studies.

At the Southeastern Ponded Alluvial site of Kelson and Swan (1990) (their site 3), ${ }^{14} \mathrm{C}$ ages from soil humics sampled from the middle-upper regions of the buried channel yielded an age of 5900-6800 yrs. BP. This channel was interpreted to have been displaced by two late Holocene earthquakes (Kelson and Swan, 1990). On the northwest margin of this site, a topographic ridge, inferred to be Pleistocene in age was found to have $9 \pm 1 \mathrm{~m}$ of left lateral displacement, indicating fault slip that pre-dates the buried channel (> 6800 yrs. BP). Their fourth site is located at Canyon Creek (Figure 1), where two fluvial terraces have been displaced by the Meers Fault, one of the terraces is capped by Browns Creek Alluvium (Holocene age) and the other consist of the Porter Hill Alluvium (Pleistocene age). The Porter Hill Alluvium is interpreted to be Pleistocene based solely on its well-developed soil profile, and has a wide estimated age range of 130 to 790 ka (Madole, 1988; Kelson and Swan, 1990). Vertical offset was estimated to be $5.1 \pm 0.5 \mathrm{~m}$ across the Holocene terrace, and $5.4 \pm 1.2 \mathrm{~m}$ across the Pleistocene terrace (Kelson and Swan, 1990). The authors suggest that these similar values of measured terrace displacements indicate that the Meers Fault has been seismically quiescent for up 
to $100 \mathrm{kyr}$ and that earthquakes may be temporally clustered in the late Holocene (Kelson and Swan, 1990). This conclusion may be problematic, as scarps that cut the Porter Hill fluvial terrace are deeply incised and eroded (Kelson and Swan, 1990) and may not represent true vertical displacement. In addition, the age of the Porter Hill Alluvium is poorly constrained and may be younger than the interpreted qualitative age of soil development.

Radiometric age results from soil humus samples have high uncertainty values, as the samples may contain organic material that has been reworked down into the underlying soil units. Along the Meers Fault it has been suggested that this contamination occurs through processes such as bioturbation, root development, and the percolation of soluble organic material (Kelson and Swan, 1990). The humic samples are corrected for the average mean residence time (AMRT), which is the estimated difference between the age of the deposit and the time that the soil humus develops on the ground surface. The longer the surface is exposed prior to burial, the greater the age difference between the carbon material within the deposit and the soil humus will be. Along the Meers Fault the AMRT has been suggested to be 200-300 years for alluvial units (Crone and Luza, 1990; Kelson and Swan, 1990). An AMRT of 200 years was used by Kelson and Swan (1990) and is based on radiometric dating of a single charcoal fragment that was found in a soil test pit adjacent to a trench site, and corresponds to the age difference between the radiometric charcoal date and the soil humic date. This AMRT contains high uncertainty, it is improbable that all of the units in the trench are exposed at the surface for the same amount of time. This site is located within a meandering stream 
environment that experiences ephemeral flood and depositional events, and therefore some units may be buried after relatively short time periods of exposure at the ground surface.

Northwest Meers Fault

An additional $\sim 17 \mathrm{~km}$ northwest section of the Holocene active trace of the Meers Fault was proposed by Cetin (1991) (Figure 1, site 6). Along the northwest section of the Meers Fault, evidence of fault displacement and coarse stratigraphy are described in natural stream bank and an irrigation ditch exposures (Cetin, 1991) (Figure 1, site 6). Hand drawn logs for the irrigation ditch lack stratigraphic location information for dated charcoal samples collected for radiometric dating. The majority of stream exposures documented by Cetin (1991) contain large regions (up to 25 meters horizontally) that are covered by either vegetation or "slope material”, where many of the stratigraphic displacements are inferred to occur (Cetin, 1991). As a result of the unreproducible paleoseismic evidence outlined in Cetin (1991), the full 18 km-long continuation of the Holocene-active Meers Fault has not been widely accepted nor included in seismic hazard assessments (Crone and Luza, 1990; Crone and Wheeler, 2003; Jones and Cecil, 1995; U.S. Geological Survey, 2006). 


\section{Methods}

This neotectonic study utilizes multiple methodologies to evaluate fault scarp morphology and earthquake timing. This investigation uses digital elevation models (DEMs) derived from airborne lidar, historic aerial photographs, and digital surface models (DSMs) derived from balloon-based photography processed using Structure from Motion (SfM) to map micro-geomorphic features (i.e. features on the order of $1 \mathrm{~m}$ to 0.25 m scale) and to identify Holocene surface fault expression. I use paleoseismic trenching paired with AMS radiocarbon and optically stimulated luminescence (OSL) dating to constrain OxCal models of paleo-earthquake timing. These techniques are described in detail below.

\subsection{Fault Scarp Morphology Mapping}

\subsubsection{Lidar Topography}

Airborne lidar (light detection and ranging) topographic data has become a fundamental tool for mapping active fault escarpments and related geomorphic features. Lidar data has revolutionized fault mapping, due to its ability to produce high-resolution digital elevation models of the bare-earth ground surface, this is particularly advantageous in vegetated environments. A laser generates optical pulses, which are reflected off surfaces and returned to the sensor. The pulse backscatter return energy is resolved in time and converted to a measurement of the distance to vertically distinct features (Harding and Berghoff, 2000). The laser ranging data is combined with differential GPS data as well as an inertial measurement unit of the plane, which tracks 
the roll, pitch, and yaw of the plane to provide geodetically referenced elevation data. The laser returns are classified by return time, and the data can be filtered to only the last return points in order to remove vegetative cover from the landscape landscape and develop a ‘bare earth’ topographic model.

Lidar data for this study was collected by the Natural Resources Conservation Service (NRCS) in 2009 and 2013, the United States Geological Survey (USGS) in year 2013, and the Federal Emergency Management Agency (FEMA) in 2015. These point data were provided by these agencies for this study and I interpolated the point cloud data into digital elevation models (DEMs) using LAStools processing software. I filtered the point clouds (LAS files) to include only the last returns and divided the data into tiles not exceeding $5 * 10^{6}$ points. I applied triangular irregular networks (TINs) to the tiled point clouds using Delaunay triangulation and rasterized these TINs to DEMs using nearest neighbor triangulation. Any triangle lengths greater than 10 meters were not rasterized. DEM resolution (grid size) varied based on point density and point clouds were processed to greater resolution DEMs in locations where appropriate.

The DEMs of each dataset were mosaiced in ArcGIS software for geomorphic analysis of the Meers Fault. I created several ArcGIS derivatives from these DEMs, including hillshade, slope, slopeshade, and curvature to the DEMs to visualize subtle topographic variations in the landscape. These derivatives were analyzed to identify and map fault related geomorphic features such as escarpments, linear ridges, closed depressions, deflected drainages, and variations in channel incision across the fault zone. I selected locations for topographic profiles perpendicular to the fault to estimate scarp 
height (h), vertical separation (V.S.) across the fault scarp, and the width of deformation of the scarp (W) following the conventions of Caskey (1995).

\subsubsection{Balloon-Based Photograph Topography and Structure from Motion (SfM)}

To examine fault scarp morphology that is not easily detected with airborne lidar, I collected balloon-based photographs and used Structure from Motion (SfM) techniques to develop a very high-resolution topographic data set at several key locations along the northwest section of the Meers Fault. SfM is a relatively inexpensive, portable, and userfriendly three-dimensional (3D) photogrammetric technique that has been used for the rapid collection of high-resolution topographic data for generating DSMs along active fault zones (Johnson et al., 2014). The technology relies on overlapping digital imagery, rather than traditional stereo-paired aerial photographs, to create 3D models that contain the topography (xyz data) and texture (RGB color values) of the landscape (Bemis et al., 2014; Johnson et al., 2014). The software uses a feature-matching algorithm, which automatically calculates the unique 3D coordinates of surface points shared between two or more overlapping images (Bemis et al., 2014). The software identifies unique camera positions and orientations and therefore can process and coregister images of varying scale and perspective, as well as objects that are occluded in some images (James and Robson, 2012; Johnson et al., 2014). Unlike lidar, SfM models from photography is unable to easily classify and filter datasets into a bare earth or digital terrain model (DTM); therefore, SfM is most effective in landscapes with sparse to no vegetation. Unmanned aerial vehicles such as drones, kites, and helium weather balloons paired with a digital camera can be operated by a one or two person field team to collect the aerial 
photographs. SfM datasets can be georeferenced using GPS positions embedded in digital images or surveyed ground control points (GCPs).

Balloon-based SfM has several advantages when compared to other aerialplatform systems: 1) In the United States, the Federal Aviation Administration (FAA) does not require a permit for flights using a tethered platform such as a helium weather balloon. 2) In mild to moderate wind conditions the balloon naturally migrates and rotates slightly, creating variations in camera position and orientation that are favorable for accurate model generation (James and Robson, 2012). 3) Weather-balloons are inexpensive and relatively easy to operate, as their movement is primarily controlled by the hiking rate and route of the user.

For this study, I used a $\sim 2.5 \mathrm{~m}^{3}$ chloroprene helium weather balloon, capable of lifting a maximum net payload of $\sim 2 \mathrm{~kg}$, which was attached to a $300 \mathrm{~m}$ nylon tether. I designed a picavet suspension system to support and stabilize a consumer grade digital single-lens reflex (DSLR) camera. I used a ruggedized Ricoh WG-5 camera with a 25mm wide lens, 35-mm equivalent focal length, and internal GPS. The DSLR camera, battery, and SD memory card weighed a total of $0.24 \mathrm{~kg}$. I set the camera to capture images at $10 \mathrm{~s}$ intervals. Between 200-220 meters of tether was released during flights, with the flight altitude being controlled by wind velocity and direction. Lower flight altitudes allow for higher point density and spatial resolution (Figure 4), yet have less surface coverage and overlap between photographs (Johnson et al., 2014). This increases the time required for both field data collection and computer processing, as well as increases the risk of not having enough image overlap. Proper route planning and 
considerations of the resolution desired are important for successful data collection, as is avoiding potential hazards such as electrical lines, barbed fences, and trees.

The spatial coverage of this data set may be the largest yet attempted by a balloon-based SfM study (personal communication; Ramon Arrowsmith). In addition, the ability of using balloon-based SfM to detect decimeter-scale fault displacements in a grassland environment has not been tested prior to this study. The subtle geomorphic expression coupled with the grassland environment makes it difficult to locate scarps related to the Meers Fault in the field, therefore flight coverage width (the footprint of a typical balloon-based photograph) was broad (up to 400 meters). After reviewing the existing lidar data and conducting field reconnaissance, I selected seven regions for balloon-based SfM analysis (labeled B1 through B7 on Figure 3), each 1 km in length by $400 \mathrm{~m}$ in width along the Meers Fault trace, primarily focused on the least vegetated and least topographically altered regions. Each dataset was flown individually at similar time of day to reduce significant variations in lighting within each dataset, decrease processing time, and allow for shorter flight times to avoid periods of intense winds. I regularly checked the image quality and adjusted camera settings as necessary and imported photographs iteratively in case of destruction of the memory card in the event of a crash. I mounted white cardboard squares with adhesive reflectors to wooden stakes and positioned these in the field to use as ground control points (GCPs). The GCP locations were collected using a handheld Garmin GPS unit $( \pm 5 \mathrm{~m})$. 


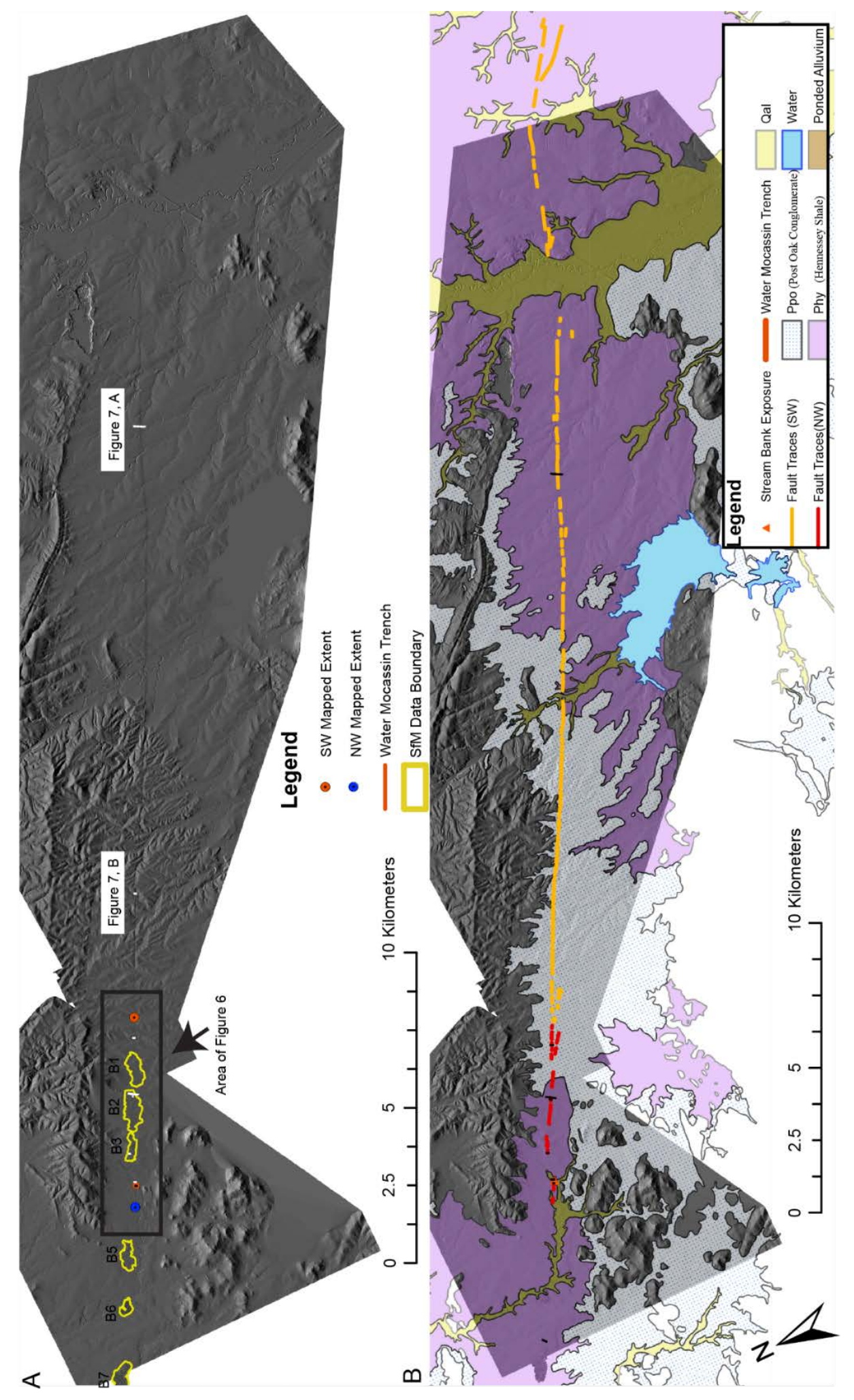

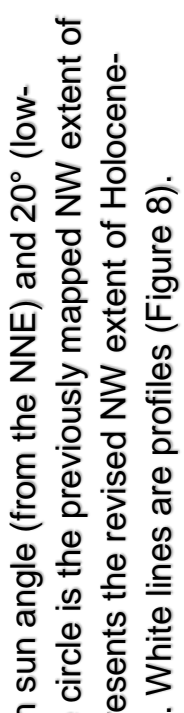

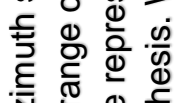
तั 융 舫 \% 言密 ه 중 둥 등 ฮ 흘 응 흠

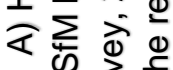

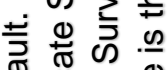
元 응 윰

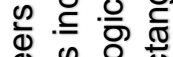
$\sum^{\infty}$ 产完心 Ф) 渮苛

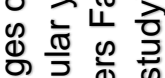

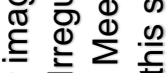
现至 这递总 ठั m) ज़

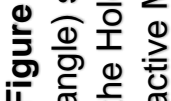


The first step in processing the data was to eliminate any photographs that were blurry, oblique to the ground surface, or within $\sim 10$ meters of the ground surface. Next, I uploaded the images to Photoscan Pro (Agisoft LLC), a commercial SfM software. The images were aligned in the software using a feature matching algorithm that also identifies camera position and orientation. Alignment was initially done using embedded GPS coordinates and processed at low quality to generate a sparse point cloud (Figure 4, C). Ground control points (GCPs) were located in images and markers were created that contain real world coordinates to georectify and further align the dataset. Dense point clouds were generated based on calibrated camera positions, GCPs, and features paired in photographs (Figure 4, B). I applied a three-dimensional (3D) polygonal mesh to the dense point cloud to interpolate a continuous digital surface model (DSM). After the surface geometry was reconstructed, the point cloud was exported for DSM manipulation, and texture was applied to generate an orthomosaic of the landscape. 

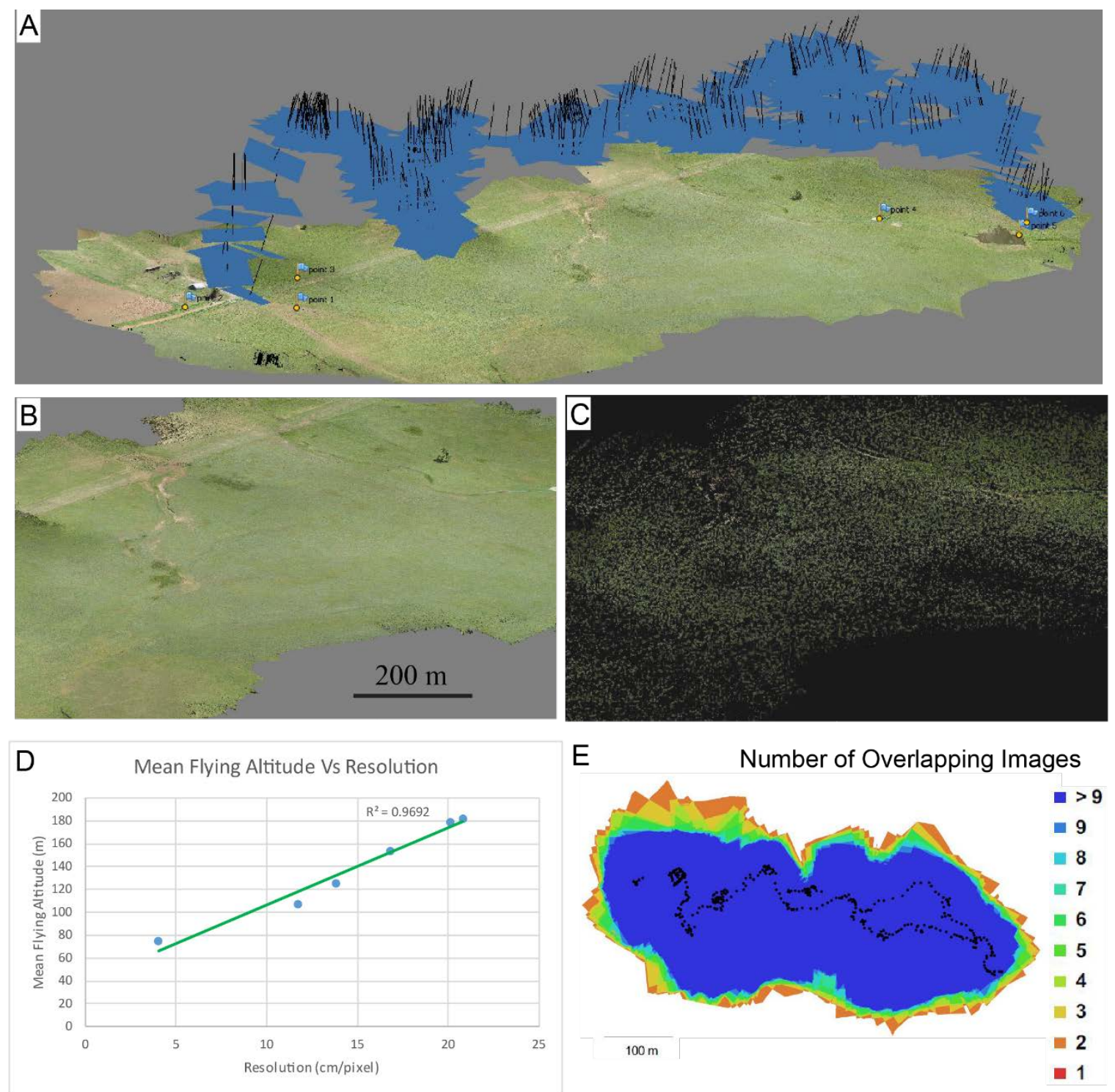

Figure 4. SfM processing stages and results from the B1 dataset. A) Orthomosaic with camera locations and ground control points (GCPS) B) Dense point cloud. C) Sparse point cloud based on the initial alignment. D) Relationship between mean flight altitude and achievable DEM resolution D) Camera locations and image overlap map.

Balloon-based SfM point clouds contain vegetation and are not bare earth models, therefore I applied a $0.01 \mathrm{~m}^{2}$ grid to the point clouds and filtered the data to only include the lowest elevation data point within each grid cell. The goal of this step was to reduce 
noise from the grassland environment by assuming the lowest point would be nearest to the ground surface. I further aligned the filtered point clouds and georeferenced these relative to lidar datasets using iterative closest point (ICP) alignment and then calculated root mean square (RMS) values (Table 1; Figure 5). To further eliminate regions within the balloon-based SfM datasets which contained high uncertainty due to increased vegetation or a lack of image overlap (e.g., along the edges of each dataset), I calculated the vertical distance between points (Cloud to Cloud distance) from the balloon-based SfM and raw lidar (all returns) datasets by differencing the SfM point cloud elevations from the lidar point cloud elevations (Figure 5, Table 1). These distances were calculated using the Cloud-Cloud distance tool in CloudCompare software and distances that were anomalously high ( $>2 \mathrm{~m}$ ) were eliminated from the datasets to remove regions that may contain unreliable data from a lack of image overlap. The final step was to interpolate the processed balloon-based point clouds to DSMs using LAStools software following the triangulation and rasterization methods described above for lidar data. I mosaiced and analyzed the DSMs in ArcGIS using the derivatives and geomorphic mapping methods outlined in the lidar section, above.

Previous work in more arid environments, containing little to no vegetation have shown successful results when comparing SfM and lidar datasets (James and Robson, 2012; Johnson et al., 2014). Here, I present results from balloon-based SfM datasets compared to existing airborne lidar datasets collected in an intracontinental grassland setting, highly altered by agricultural practices (Figure 5, Appendix A). To eliminate spatial variance from absolute GPS positioning of ground control markers used 
in balloon-based SfM and lidar datasets, an iterative closest point algorithm (ICP) was applied to the each balloon-based SfM and lidar dataset pair. This creates a global alignment relative to the two datasets based on all points in the datasets, rather than surveyed locations. The balloon-based SfM datasets used for this comparison are used for mapping, and have previously been aligned and scaled to lidar to georectify the point clouds, filtered to contain only the lowest point within each $0.01 \mathrm{~m}^{2}$ grid cell, and further filtered to remove points with a vertical distance greater than $2 \mathrm{~m}$ from lidar point clouds. The lidar datasets were used as a reference for the algorithm and the ballon-based SfM point clouds were translated and rotated (rigid body transformation) to minimize the distance between matching point pairs. The point to point three-dimensional distance and Root Mean Square Error (RMSE) was initially calculated using manually selected features identified in both datasets and further refined by an ICP algorithm using CloudCompare Software. After RMSE values were minimized, the absolute Cloud to Cloud (C2C) distances between the lidar and balloon-based SfM datasets were measured. Lidar point clouds were used as reference datasets due to their lower point density and the distance between the nearest point in each SfM point cloud was located and measured using a least square plane distance model. The vertical component of the Euclidian distance was measured between the two closest points and reported as the Cloud to Cloud distance (Figure 5, Table 1).

The SfM point clouds are qualitatively presented (Figure 5A and 5B) and quantitatively assessed (Figure 5C, Table 1). Major fault-related geomorphic features identified on lidar DEM derivatives are also evident in balloon-based SfM hillshade and 
slope maps (Figure 5A and 5B). SfM datasets B1, B2, and B3 are southeast of the Water Moccasin trench site in agricultural fields with $<1.0 \mathrm{~m}$ tall grass and capture fault expression. The fault trace is visible on the east side of the B3 dataset and continues to the north of the B3 dataset flight coverage. The B5, B6, and B7 datasets are located northwest of the trench site in regions mapped by Cetin (1991). Neither field mapping nor balloon-based SfM datasets reveal a fault morphologic signature in these locations. The mean flight altitude is directly correlated to the achievable resolution ( $\mathrm{cm} / \mathrm{pixel})$ of the point cloud-based DSM and lower altitude balloon flights increase point density and resolution (Figure 4), however, a lower flight altitude results in a decreased width of coverage in the image. 


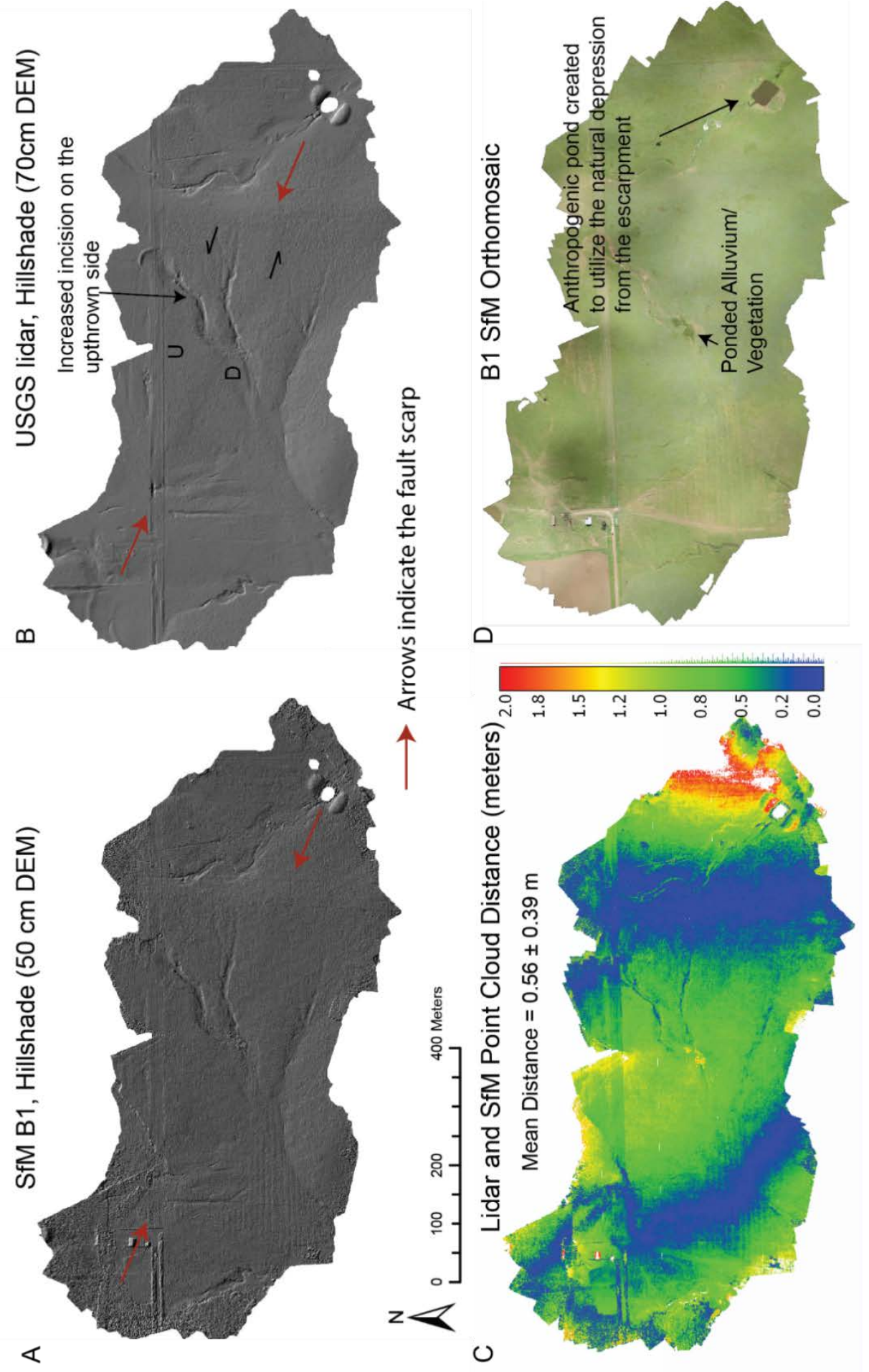

$\sum_{\omega}$

«웡응

ํㅗㅇ 을 은

है 융

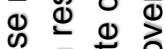

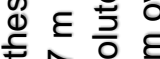

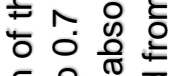

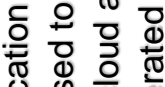

ชู엥 흔

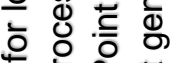

琼口

m

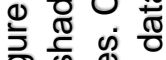

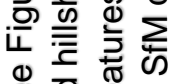

ญ ర

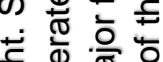

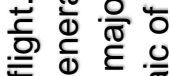

하웡

๑ क 항

$\stackrel{\oplus}{\ddagger}$ 금 응

흐 ฮิ

ㄷํำ

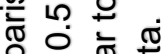

을 을

엉 응

행

으웡

흔흔 흔 $\sum_{\omega}^{\infty} \sum_{\omega} \frac{\pi}{\frac{\pi}{0}}$

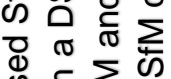

कू

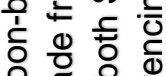

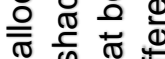

Ф Ф) 焉

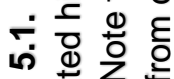

뜐 言高厗訶 

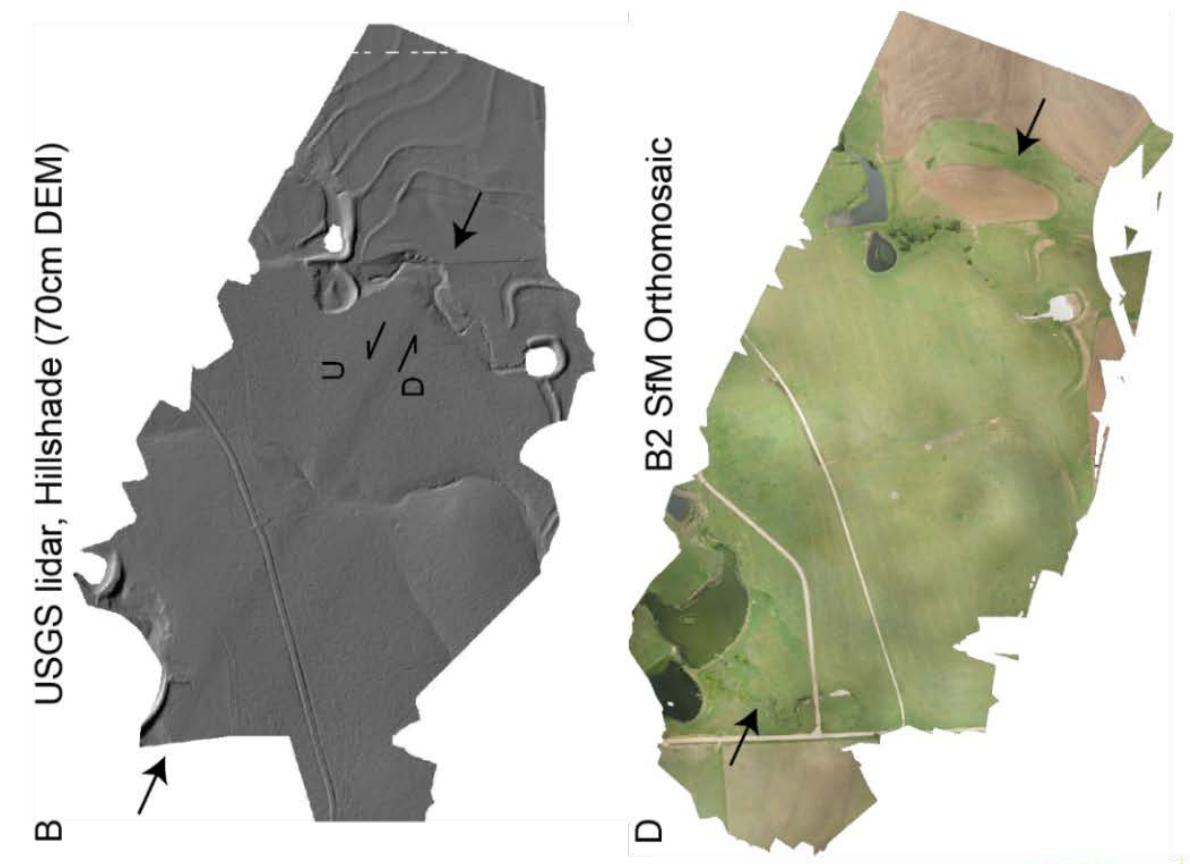

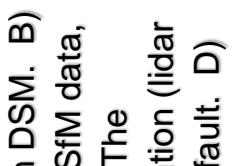

เ $\subseteq$ क

웡

空

흥

둔

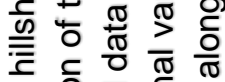

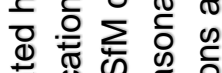

떤

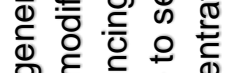

ळ

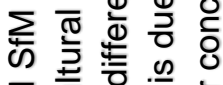

ఫ

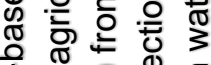

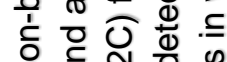
흔

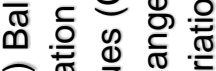
《需 $\frac{}{\pi}$ 등 을 N

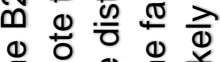
过怘焉 흔

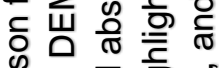
黄 릉응 은

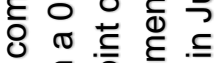
흥 흥ㅎㅁ 흥

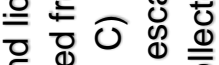
क

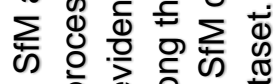
흥 흐응 흥 记

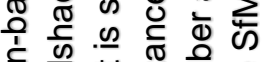

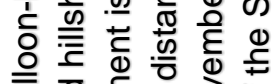

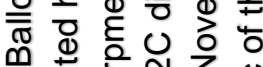
$\infty$ ๘ँ ง ब

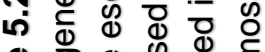

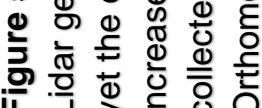




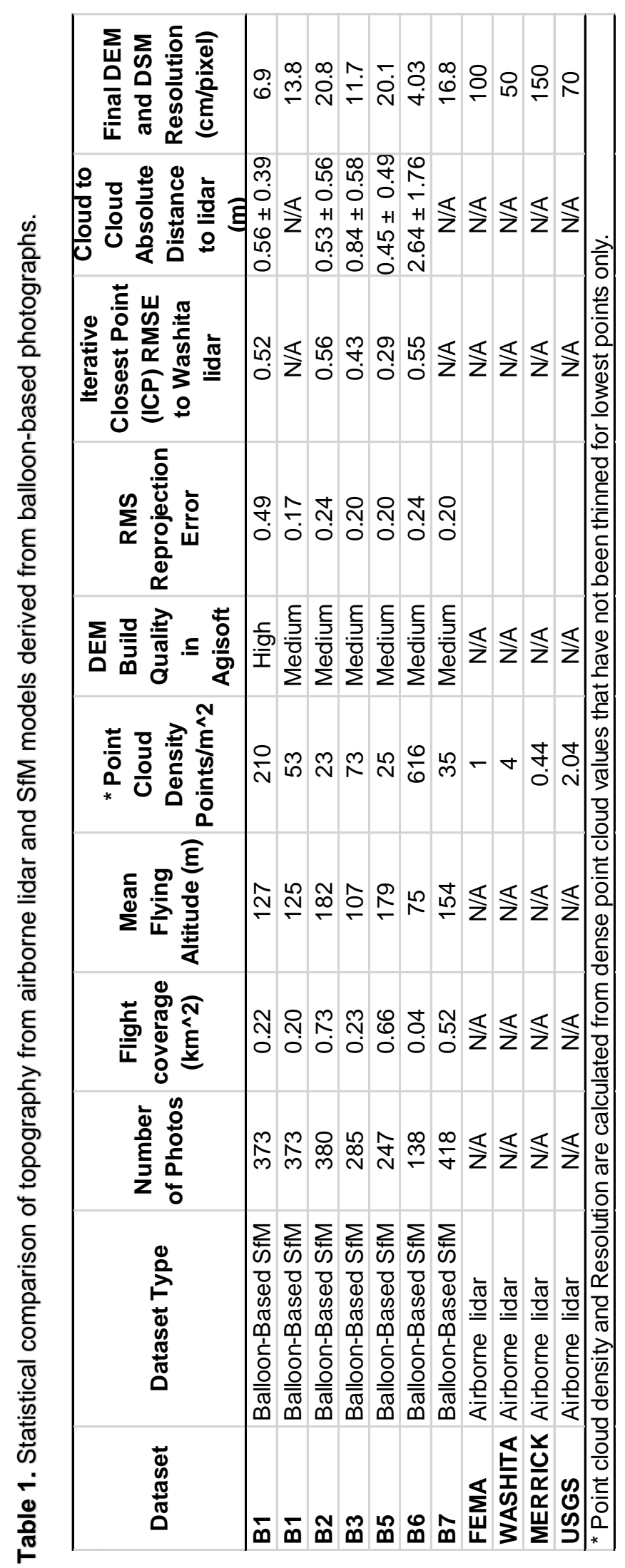




\subsubsection{Historical Aerial Photograph Topography}

The Oklahoma Corporation Commission’s Oklahoma Historical Aerial Digitization Project (OHADP) and the Oklahoma Geological Survey provided aerial photographs from 1942 and 1964-1966 for use in this study. The United States Department of Agriculture (USDA) collected the photographs with 60\% overlap between images in the flight direction and 30\% overlap for images in adjacent flight lines. I printed and mapped fault-related topography was mapped onto mylar overlays using a 3D tabletop stereoscope. I also aligned and georectified the images in Agisoft Photoscan to further evaluate the historical landscape. Features, such as road intersection and buildings visible in the photographs and the modern landscape were used as ground control points to georectify the mosaic. Using Agisoft Photoscan, I generated a dense point cloud and interpolated this into a DSM model using LAStools software, the resulting model and orthomosaic were used as base imagery in ArcGIS for geologic and geomorphic fault trace mapping.

\subsubsection{Geologic and Geomorphic Field Mapping and Reconnaissance}

I ground truthed geomorphic features that were initially identified with lidar and balloon-based SfM data. The field investigation involved; cleaning and studying stream bank exposures that crossed the projection of the Meers Fault, mapping geomorphic features and predominate lithological float material in a swath across the fault, and balloon photograph acquisition flights of six regions along the fault (Figure 3). Geomorphic features including linear ridges, monoclines and surface warping, closed 
depressions, suspected deflected drainages, and linear trends of altered bedrock float were mapped.

I targeted stream channels that traverse the fault projection as potential natural exposures that may show evidence of surface faulting and stratigraphic displacement or warping across the fault. I also located and visited stream cuts indicated by Cetin (1991) that showed evidence of faulted stratigraphy. Along the fault projection I extensively dug, scraped, and cleaned the stream banks to expose alluvial stratigraphy, and bedrock; where present. The stream investigations yielded no conclusive results due to the presence of thick flood deposits coating stream banks, heavy vegetation, and slump material. Evidence of surface faulting was not found at the Cetin (1991) study sites, with the exception of the irrigation ditch adjacent to the new Water Moccasin paleoseismic site (Figure 1, site 6). Where possible, I mapped the predominate float lithology along the fault as well as mapped bedrock lithologies where exposed in stream cuts.

\subsection{Water Moccasin Paleoseismic Site}

\subsubsection{Active Source Seismic Survey}

Prior to excavating the paleoseismic trench at the Water Moccasin paleoseismic site, I deployed a $14.2 \mathrm{~m}$ long active land seismic survey using $2 \mathrm{~Hz}$ receivers (geophones) perpendicular to the fault scarp to image the subsurface fault geometry. I spaced geophones $20 \mathrm{~cm}$ apart in a $\mathrm{N} 30^{\circ} \mathrm{E}$ trending line. Seismic velocity (Appendix E) and refraction data were collected using a Geometrics 3X 24-channel geode survey. I generated the seismic source by striking an aluminum hammer plate with a 
sledgehammer every $0.8 \mathrm{~m}$ along the survey line and $\sim 0.5 \mathrm{~m}$ to the east of the receivers, as well as at the north and south ends of the survey line. The seismic source generates Rayleigh waves, which travel through the sub-surface and image variations in the physical properties of different depositional units.

\subsubsection{Paleoseismic Trenching and Irrigation Ditch Mapping}

I selected the Water Moccasin paleoseismic trench location from a combination of lidar mapping, profiles across the scarp, the geophone survey, and field observations. The slot trench was $21 \mathrm{~m}$-long and excavated sub-perpendicular $\left(\mathrm{N} 25^{\circ} \mathrm{W}\right)$ to the fault scarp and was excavated using a rubber-tire backhoe with a 24-inch wide bucket. A 6 mlong dog-leg oriented $\mathrm{N} 76^{\circ} \mathrm{W}$ was also excavated to capture any potential $\mathrm{NW}$-trending fault splays. Vertical hydraulic shores were positioned every $1.5 \mathrm{~m}$ to $2 \mathrm{~m}$ laterally to reinforce the trench walls to prevent cave-ins and promote safe working conditions. I surveyed the trench footprint using a Trimble GeoXH differential GPS unit and postprocessed the data in GPS Pathfinder Office Software. Cleaning backhoe smear from the trench walls involved scraping and hammering, and was done by the field team over several days to expose unaltered stratigraphy. Once cleaned, I installed a nail grid $\left(1 \mathrm{~m}^{2}\right)$ on the walls to map the stratigraphic relationships and fault-related deformation in a local coordinate system. I mapped unit contacts in the trench walls using roofing nails to document detailed stratigraphic variations and soil horizons. I imaged the trench walls by taking a dense grid of overlapping photographs. The images were filtered to eliminate those which were blurry, and masked to eliminate areas such as hydraulic shores and tools that might interfere with image mosaicing. I aligned and mosaiced the photographs 
using Agisoft Photoscan Software to create high resolution orthomosaics for field mapping, following the trench wall photomosaic workflow of Reitman et al. (2015).

After printing orthomosiacs of the trench walls, I mapped stratigraphic and structural relationships, notes, and observations on the images. Age dating samples $\left({ }^{14} \mathrm{C}\right.$ and OSL), and bulk sample locations were noted on the trench logs. I reviewed the trench logs, and upon return to Portland State University I drafted the field logs in ArcGIS and Adobe Illustrator to create the final, interpreted trench logs. I constructed a stratigraphic column based on my unit descriptions, age results, and trench logs.

I located the irrigation ditch cited by Cetin (1991) 15 m east of the trench site along the fault projection. I scraped, cleaned, photographed, and logged the exposure in the field following the trenching and photomosaic conventions described above. Macroorganic material was not apparent in these units. I selected bulk sediment samples from distinguishable stratigraphic units across the fault for radiocarbon analysis.

\subsubsection{Dating Techniques}

\subsubsection{Radiocarbon Dating}

I carefully examined trench walls for identifiable macro-organic material, which was limited to detrital charcoal at this site. I collected, described, photographed, and mapped the location of each macrocharcoal sample while in the field. Visible organic material was rare in the trench walls. I also collected bulk sediment samples from each distinguishable unit for laboratory analysis for the presence of concealed macrocharcoal, microfossils, and microcharcoal at Portland State University. Bulk samples were added 
to deionized (DI) water and put into a Branson 1510 ultrasonic cleaner for sonication to separate and float organic material. I examined macrocharcoal and microcharcoal under a Leica Mz95 binocular microscope for determination of organic content, sample size, and morphology. Samples were photographed using an Excelis Accu-scope microscopic camera at 15.75x magnification. I sent five bulk samples that lacked visible organic material to PaleoResearch Institute for further analysis for microcharcoal extraction and only three of these yielded sufficient microcharcoal material for AMS radiocarbon dating.

I collected a total of 21 detrital macrocharcoal samples from the trench walls. After microscopic analysis, only five macrocharocal samples were determined to contain dateable, organic material and were sent to Beta Analytic for ${ }^{14} \mathrm{C}$ AMS dating. After sample processing, only one of the samples sent to Beta Analytic yielded sufficient mass for ${ }^{14} \mathrm{C}$ dating (Table 2; sample WM_16_RC15). Detrital charcoal sample images are presented in Appendix F.

\subsubsection{Optically Stimulated Luminescence Dating}

Optically Stimulated Luminescence (OSL) is an ideal dating method for sandy, quartz-rich deposits that lack organic content. Luminescence dating provides an estimate of the time of deposition of a unit, determined by the last exposure of sunlight to sand grains (Gray et al. 2015). The basic principle relies on the ability of quartz and feldspar crystal lattices to absorb and store free electrons that accumulate after burial from the ambient background radiation (ionizing energy) generated by radioisotopes in surrounding sediments (Gray et al., 2015; Rittenour, 2008). The luminescence signal 
increases with time as ionizing energy accumulates in the crystal lattice. If the grain is eroded and exposed to sunlight, the radiation signal is reset by solar energy (Gray et al., 2015; Rittenour, 2008). Solar resetting (also known as bleaching) occurs as buried sediment is eroded and transported. However, partial bleaching can occur if the luminescence signal of the sediment is not completely reset before it is again buried, which will result in an age which is older than the time of deposition (Gray et al., 2015; Stokes et al., 2001). Quartz grains are preferred for OSL dating because its luminescence signal is more readily reset by sunlight (Stokes et al., 2001). Because of the low abundance and small sample size of detrital charcoal samples visible in the trench, I selected two OSL samples from fluvial deposits. These samples were analyzed by Shannon Mahan at the USGS Luminescence Dating Laboratory.

\subsubsection{Oxcal Bayesian Statistical Age Modeling}

I developed an OxCal Bayesian statistical age model (Bronk-Ramsey, 2009) for the site that incorporates radiocarbon age results, OSL age results, and unit depth to create an age-depth model. This model calibrates ${ }^{14} \mathrm{C}$ ages using the IntCal13 carbon atmospheric curve (Reimer et al., 2013) and uses stratigraphic ordering information to better constrain unit ages based on relative age information (after Lienkaemper and Bronk-Ramsey, 2009). 


\section{Results}

\subsection{Fault Zone Morphology Mapping}

I used lidar, balloon-based SfM datasets, and historical aerial photos to map tectonic geomorphic features including the fault escarpment, linear ridges, incised channels on the up-thrown block, and closed depressions with ponded alluvium on the down-thrown side of the fault (Figure 6, 7). These features were ground truthed in the field to confirm that the mapped morphologies are not anthropogenic features.

Derivatives of DEMs, including hillshades with varying sun azimuth and sun altitude values, slope, curvature, and contour maps were used to detect subtle topographic surface expression of the Meers Fault (Figure 6). I document tectonic geomorphic features in Holocene surfaces along the projection of the Meers Fault $\sim 6.1 \mathrm{~km}$ to the northwest of the current terminus of the Holocene trace of the fault indicated in the Quaternary fault and fold database by the U. S. Geological Survey, (2006) (see Figures 3A and 6). Topographic expression of the fault is subtle, yet relatively continuous throughout this \%6.1 km-long newly-identified Holocene-active portion of the fault, and displays southwest facing scarps. I observe increased incision of ephemeral streams on the upthrown side (northern side) of broad monoclines as well as ponded alluvium at the base of the escarpment, immediately south of the fault (Figures 6C and 6D). Evidence of lateral displacement, such as deflected drainages and offset terrace deposits along the fault are not apparent in the data. Lateral displacements of less than $2 \mathrm{~m}$ are not distinguishable from the sinuosity of natural meandering streams in this basin (Figure 6). Thus, I cannot confirm the observation of sinistral offset reported by Cetin (1991). 
In regions along the revised, longer Holocene-active fault trace, the landscape has been heavily altered by anthropogenic practices, including agricultural terracing. Using georectified 1942 aerial imagery, I document a N60 $\mathrm{W}$ trending, southwest facing escarpment along the additional $~ 6.1 \mathrm{~km}$-long Holocene-active fault trace identified in this study (Figure 8). In many locations, the natural landscape is better preserved and the fault scarp is more easily distinguished in the historical photomosaic than in modern lidar and balloon-based SfM data, as these 21-century datasets post-date agricultural alteration of the landscape in locations (Figure 8).

\subsubsection{Scarp Perpendicular Topographic Profiles}

I used fault perpendicular topographic profiles to estimate vertical separation of the ground surface across the fault scarp, scarp height, and scarp deformation width. These profiles highlight differences in the morphology of the fault scarp in the two local bedrock lithologies, the well indurated, Post Oak Conglomerate, and the weak Hennessey Shale (Figure 7; Appendix B). Selected profile locations are shown in Figure 3 and 6A and listed by distance along the fault in Table 4. Broad surface deformation is apparent in the profiles, particularly within the Hennessey Shale Formation (Figure 7). Scarp profiles from balloon-based SfM datasets show higher noise to signal than bare-earth lidar profiles (Figure 7). The high frequency variations in the balloon-based SfM surface data are due to abundant variations in the height of vegetation (grass and agricultural crops). Regardless, the balloon-based SfM data still capture the overall signal of monoclinal warping. 
My topographic profiles are most closely spaced along the northwest section of the Holocene-active stretch of the Meers Fault (Figure 9), where the scarp is characterized by decimeter surface offsets, much less than offsets observed on the main southeast section of the Meers Fault. There, where the fault cuts Post Oak Conglomerate bedrock, the fault scarp appears highly weathered, yet remains distinct and exhibits a vertical surface offset up to $0.6 \mathrm{~m}$ over horizontal distances typically of $\sim 7$ to $21 \mathrm{~m}$ wide (Figure 7 C,D,H; Appendix B). Broad surface deformation, possibly as monoclonal folding is the primary style of deformation where the fault traverses the Hennessey Shale. Along this same stretch of the fault, escarpments in the Hennessey Shale exhibit broadly similar magnitudes of vertical surface offset to those in the Post Oak Conglomerate, with vertical surface offsets up to $0.8 \mathrm{~m}$. However, escarpments in the Hennessey Shale are much wider ( 10 to 50 meters wide) (Figure 7 E,F,G,I).

I also analyzed topographic profiles for vertical surface estimation along the southeast section of the Meers Fault (Figure 7A, 7B, 9; Appendix B). Here, my analysis was conducted at a lower spatial density. Surface offsets along the southeast section of the Meers Fault are larger than those measured along the northwest section (Figure 9; Appendix B). The largest vertical surface offsets are observed along the central portion of the Meers Fault, and offsets taper both to the northwest and southeast (Figure 9. Scarp width is much greater in the Hennessey Shale bedrock than in the Post Oak Conglomerate (Figure 7, 14; Appendix B; Table 4). 


\subsubsection{Geologic and Geomorphic Field Mapping}

To confirm my remote lidar and balloon-based SfM mapping results, I mapped linear escarpments along fault strike, incised channels, and ponded alluvial sites. I confirmed several features mapped on lidar and balloon-based SfM derivatives. This step was valuable to this analysis, as some preliminary fault-related features, were found to have been created by anthropogenic alteration. For example, several sites mapped as ponded alluvium were determined to be stock ponds and some linear ridges were actually agricultural terraces.

I modified 1:100k lithological contacts from the Oklahoma Geological Survey (Stanley and Miller, 2005) and slightly modified these based on field mapping of float material found while traversing the fault as well as stream bank exposures (Figure 6D). The predominate bedrock float transitions from Post Oak Conglomerate to Hennessey Shale 1.8 kilometers northwest (measured along fault strike) of the previously identified northwestern end of the Holocene-active Meers Fault (Figure 6D). Here, within Hennessey Shale, surface deformation is primarily accommodated by monoclinal warping (Figure 6, 7), and the fault traverses this lithology for the remainder of visible surface expression (Figure 6). 


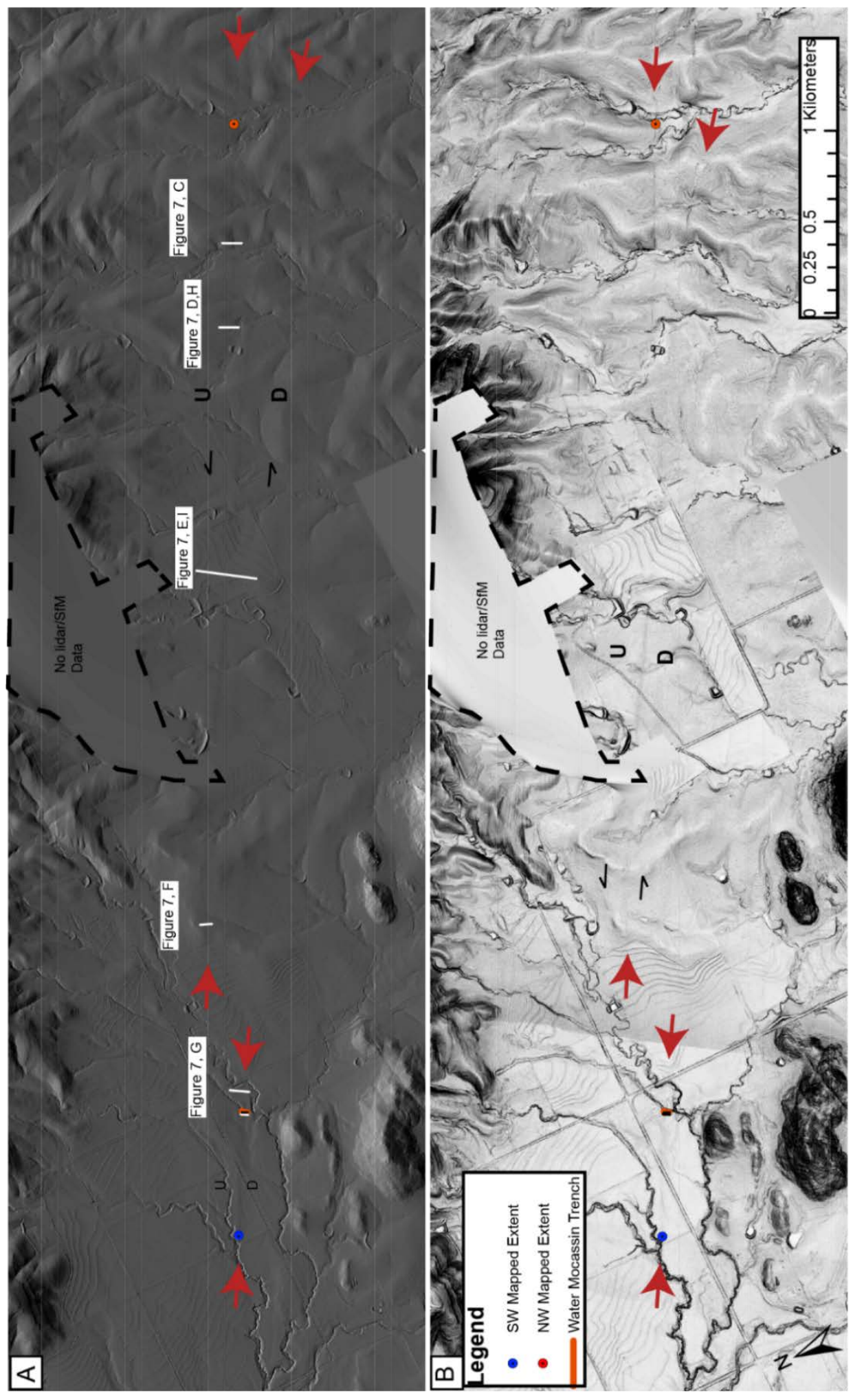

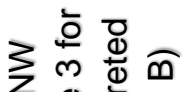

잉 형

응 은 岳

웡

일을

응 종 党 훈

있

흐능

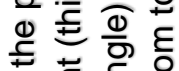

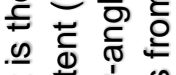

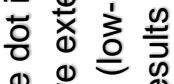

잉 인

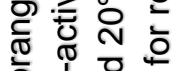

헝 원

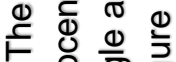

픅응 흫 흔

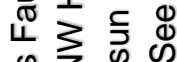

잉

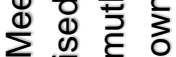

ब ग

廿ั0

은 융

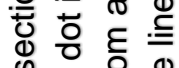

心 원

之就交

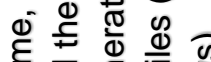

है

讷

뜌

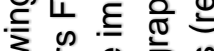

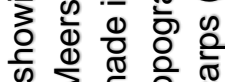

क $\sum_{\infty} \frac{\pi}{\infty} \frac{0}{0}$

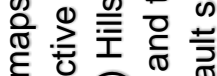

ह 苋宁䒕

D

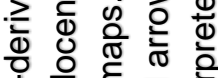

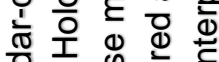

은

$\exists \stackrel{0}{=} \stackrel{0}{\circ}$

อ

는

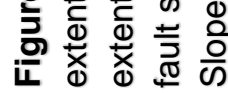




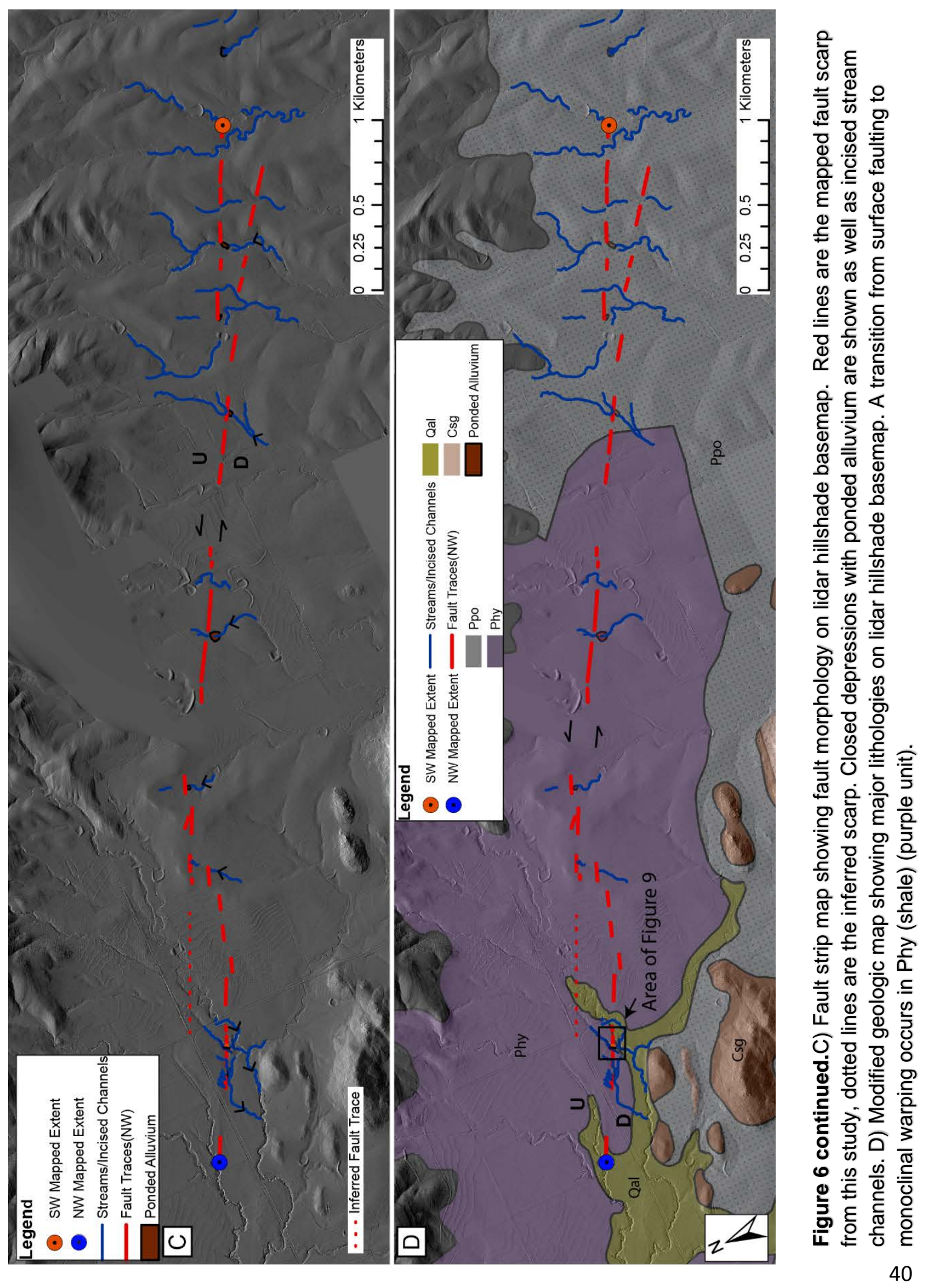



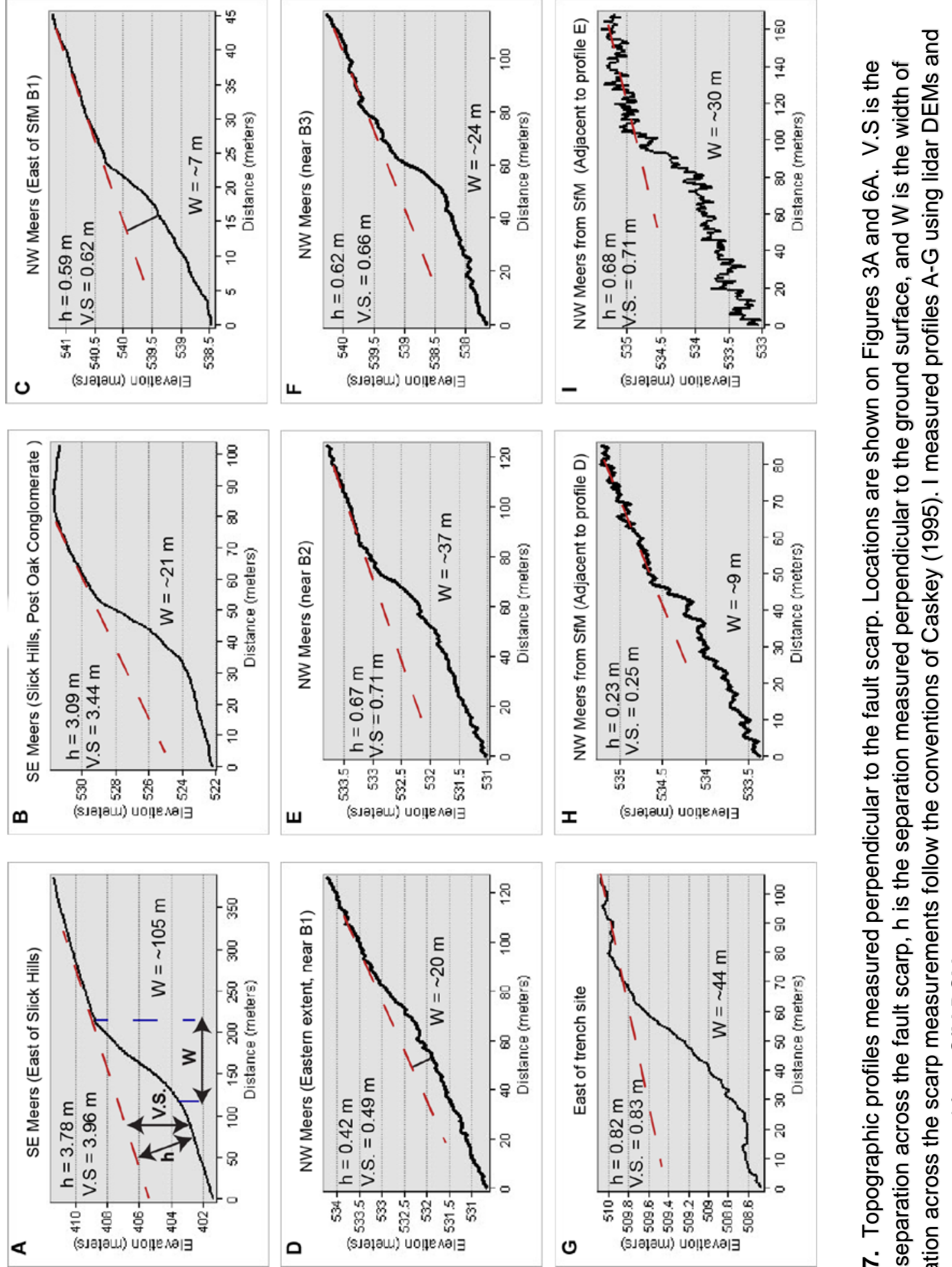

드ㅇㅡㅡ

응 윰

ज ญ 巳

ญ 으

는

을 을 엄

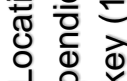

은 은

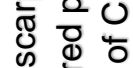

辰

๕

등 응

흔 $\frac{0}{\pi}$

ฮํㅡㄹ 은

ํㅡㄴ 은

웡 응

는

ฮั

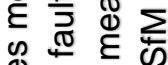

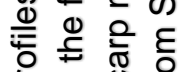

흥 矛

은 Ð

तั

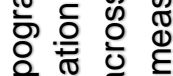

응 휴 ฮ

웡 을

ก क

흔 

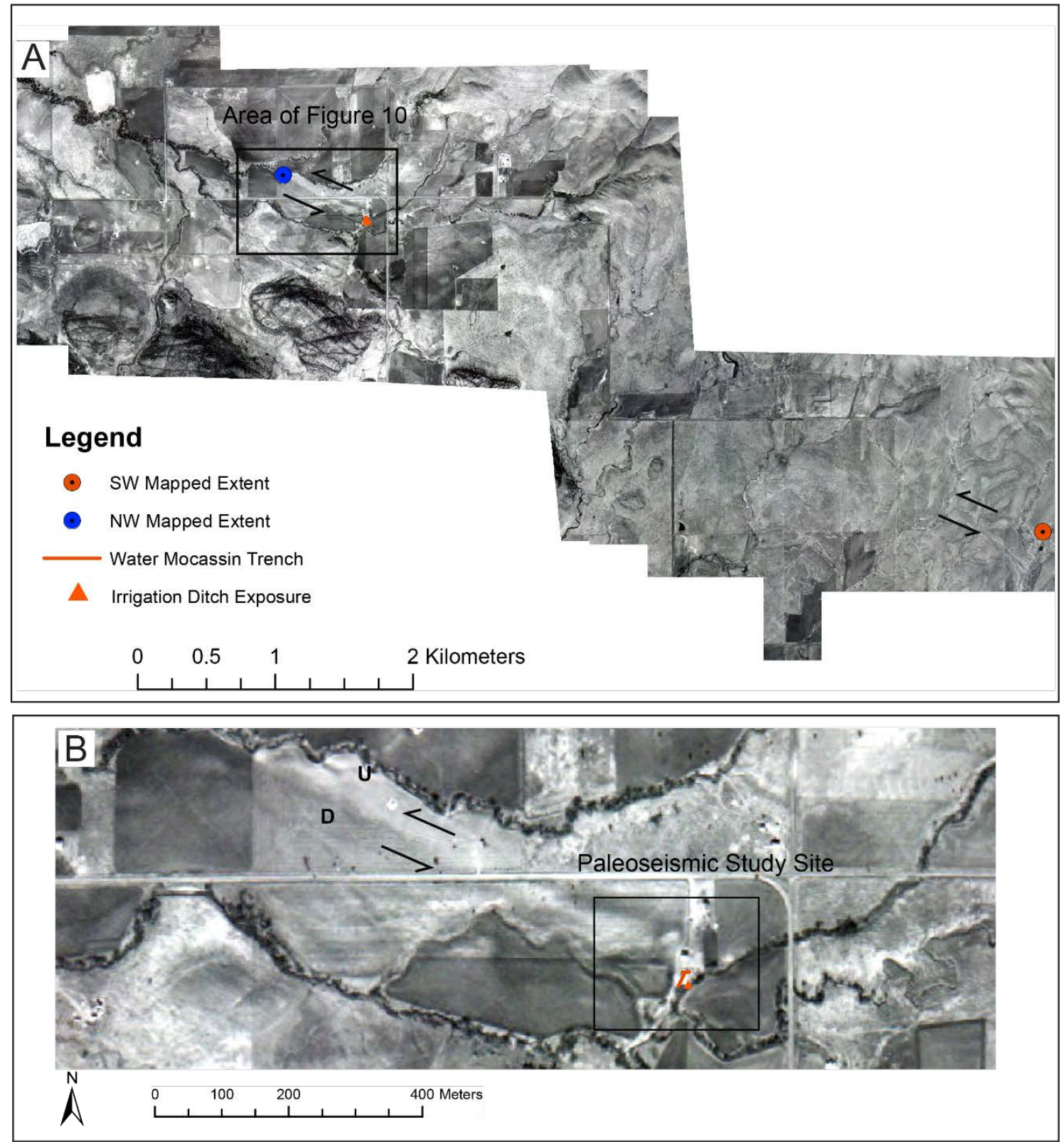

Figure 8. A) Orthomosaic of 1942 aerial photography along a small portion of the northwest section of the Meers Fault. The black rectangle is the location of (B). The landscape had experienced less anthropogenic agricultural alteration at this time. B) A zoom-in of the imagery

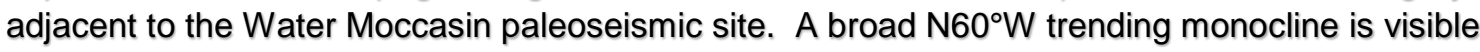
in the imagery and coincides with the fault morphology mapped using lidar and balloon-based SfM DEMs. The Water Moccasin (WM) paleoseismic study site is shown by the black rectangle (see Figure 10). 

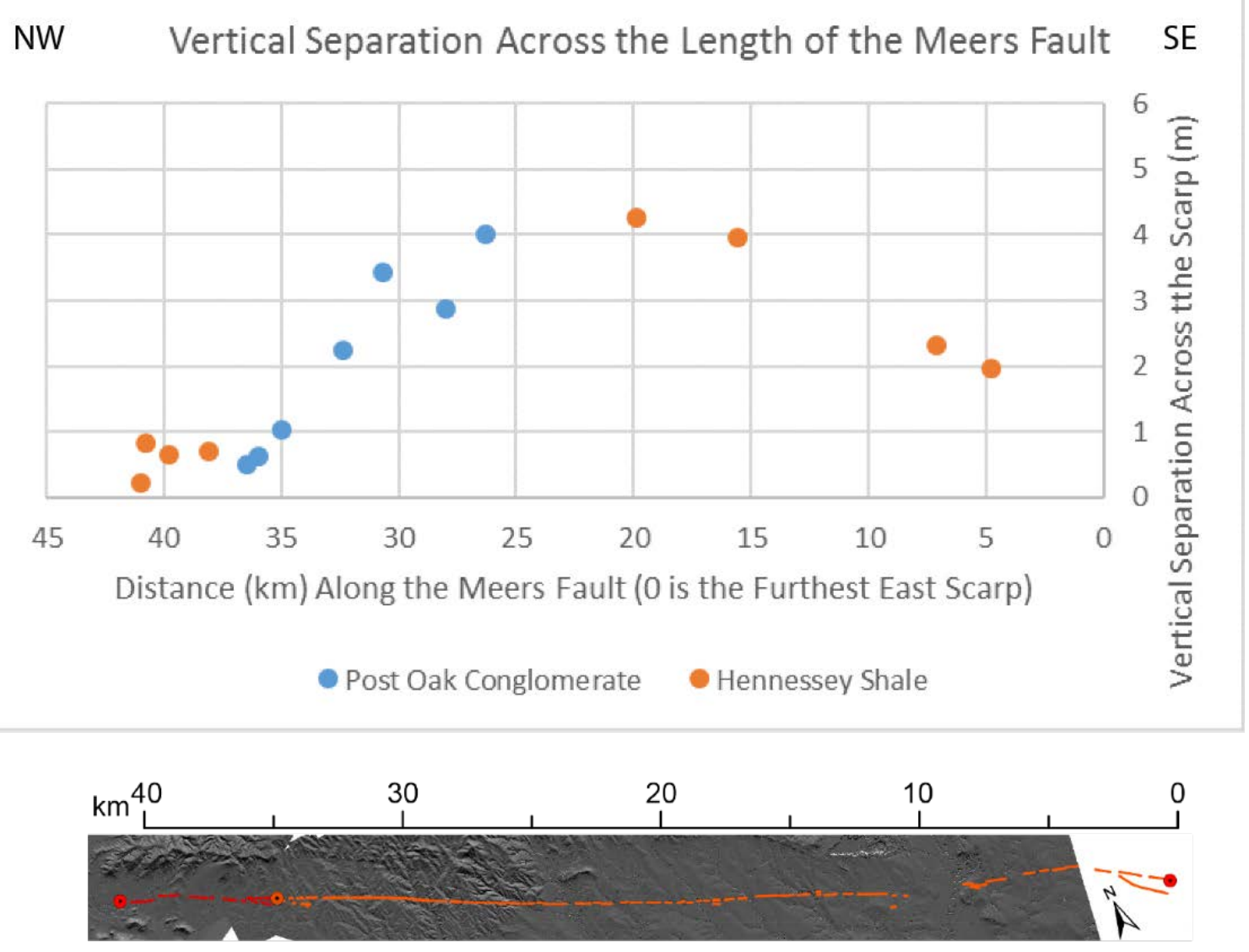

Figure 9. Plot of vertical surface offsets across the Meers Fault. The southeastern section of the fault starts on the far right of the graph $(0 \mathrm{~km})$. The northwest section of the fault is between 37 $\mathrm{km}$ and $43 \mathrm{~km}$. Decimeter displacements are observed along the northwest section. This subtle morphology was previously unmapped. Displacement values are measured from fault perpendicular topographic profiles. See Figure 7 and B1 (in appendix B) for topographic profiles. See Table 4 for summary of data shown on this plot. 


\subsection{Water Moccasin Paleoseismic Site}

The Water Moccasin (WM) paleoseismic site is located within relatively thin Quaternary deposits that overlie Hennessey shale bedrock (Figure 6, 10). The site is located adjacent to a small meandering ephemeral stream that flows roughly northeast to southwest (Figure 10). I selected a trench location within the floodplain of the stream, which has experienced seasonal overbank flooding and deposition of sediment prior to the construction of an irrigation ditch in the 1970's (Personal communication, Dean Reeder), with hopes that this site had relatively high sedimentation rates and a historic irrigation ditch and the paleoseismic trench would expose datable material to bracket the ages of pre-historic earthquakes.

\subsubsection{Historic Irrigation Ditch Exposure}

The historic irrigation ditch was created to divert ephemeral stream flow from the low-relief channel that bypasses the western edge of the WM site and into an adjacent stream channel $\sim 50 \mathrm{~m}$ south of the site (Figure 10A). Excavation of the irrigation ditch, combined with diverted stream flow since the 1970's, has formed a new channel $\sim 60$ mdeep (dashed black line on Figure 10A). The subvertical walls of this irrigation ditch expose faulted stratigraphy and a scarp derived colluvial deposit (Figure 10C). In the northern side of the irrigation ditch, Permian Hennessey Shale is in fault contact with inferred Holocene age scarp derived colluvium. Hennessey Shale bedrock is exposed $~ 8$ $\mathrm{m}$ to the south and has $\sim 1.5 \mathrm{~m}$ of vertical offset across the fault (Appendix D, D2). Silt deposits overlie the fault as well as slump material from modern tree throw (Figure 10C). 


\subsubsection{Water Moccasin Paleoseismic Trench Location}

I excavated the WM trench $~ 15$ m northwest of the irrigation ditch and perpendicular to a, $\mathrm{N} 60^{\circ} \mathrm{W}$ trending break in the surface gradient (gentle $1-2^{\circ}$ slope to the SW) (Figure 10A) where I estimate $\sim 0.2 \mathrm{~m}$ of vertical surface offset (Figure 10B). The WM trench is collocated with my geophone seismic survey (Figure 10A; Appendix E). The fault scarp is very subtle at the site due to overbank deposition and agricultural practices. The WM trench is located in a small grassy pasture near a cattle ring feeder. This property has been owned by the Reeder family for over 90 years, therefore the property owner was able to explain the land use history and areas of modification during ranching practices.

Test auger holes across the trench site were completed prior to excavation and revealed that thin (10-30 cm-thick) anthropogenic fill material was present at the trench site. However, this historic material became thinner towards the southwest and pinched out in the vicinity of the fault projection, consistent with material being pushed away from the ranch facilities located north of the trench site. Importantly, the natural, prehistoric A soil horizon was preserved below the fill, precluding the notion that native materials had been stripped from the potential trench site during ranching activities. The test auger holes also revealed that the A horizon soil was thicker on the down-thrown (southwest) side of the fault. I found the WM trench site to have a moderate sedimentation rate with overbank flood deposits and well developed soils. 


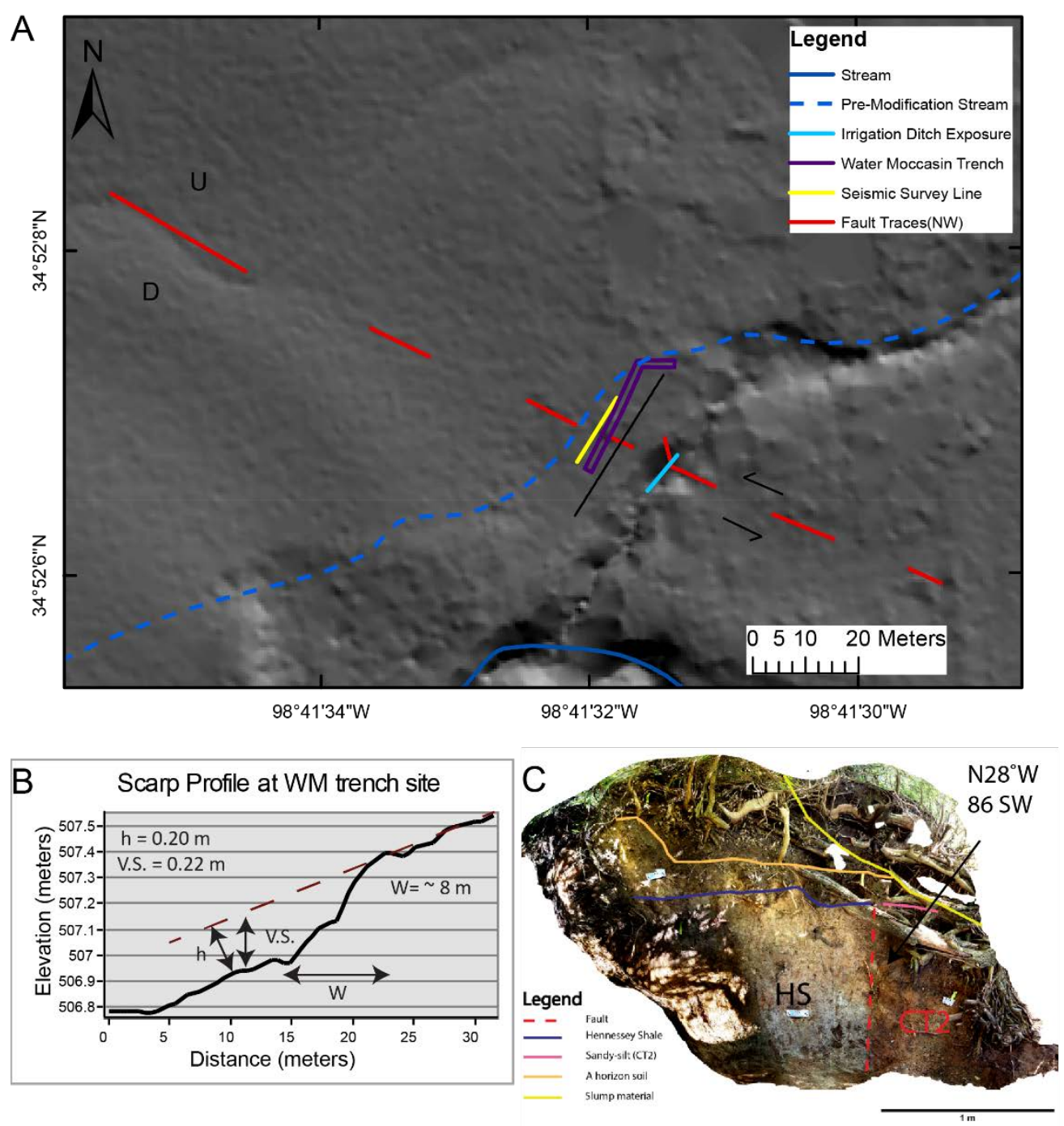

Figure 10. A) Slope-shade site map from generated from lidar for the WM site showing the fault scarp (dashed red lines), the trench footprint (purple polygon), the seismic survey (yellow line), the irrigation ditch exposure (green line), the topographic profile (black line). Ephemeral stream channels are shown in blue. Locations of $X X$ and $Y Y$ were surveyed using a differential GPS. B) Topographic profile with $0.21 \mathrm{~m}$ of vertical surface offset across the scarp. C) Fault relationships exposed in the southeast wall of the irrigation ditch. Hennessey Shale (HS) is in fault contact with fault-derived colluvium (CT2) that consists of silt to gravel up to $1 \mathrm{~cm}$. Silt units are located above these units and are partially covered by a recent slump deposit from tree throw. After cleaning the exposure, the sharp fault contact is visible across the floor of the ditch and on the northwestern wall of the ditch floor and is oriented N25 W (see short red line in A). 


\subsubsection{Water Moccasin Trench Stratigraphy}

At the trench site, I exposed Hennessey Shale bedrock, fluvial gravel, ponded alluvial, and overbank flood deposits as well as a silt with strong blocky pedogenic structure, slope-derived colluvium, and onlapping massive silts that pinch out to the north (Figures 11, 12, 13). The oldest unit observed in the trench is the Permian Hennessey Shale (unit 5), consisting of strongly weathered and oxidized clay-rich shale. Unit 4 overlies Hennessey Shale in the northern half of the WM trench and is a grayish-brown massive silt with sparse gravel, abundant carbonate nodules, and is overprinted by a blocky pedogenic structure with translocated clay films. Stratigraphic units 3a - 3e are a package of moderately-inclined $\left(\sim 35^{\circ}\right)$ interbedded fluvial gravel and clayey silt deposits. Subunit 3e is a $10-20 \mathrm{~cm}$-thick massive silty-clay with a buried A horizon developed on it. Units $2 \mathrm{a}-2 \mathrm{~g}$ are fluvial deposits, ranging from medium to coarse gravel deposits (unit 2a, 2g) to sandy-silt deposits with abundant fine-grained, sub-rounded gravels (unit 2d, 2f). Subunit $2 \mathrm{~h}$ consists of clayey-silt scarp-derived colluvium with $\sim 20 \%$ finegrained gravel clasts that is overlain by a massive silt (subunit 2e). Subunit $2 \mathrm{~g}$ is a coarse-grained gravel deposit and caps unit 3a - 3e. Subunits $2 \mathrm{f}-2 \mathrm{~d}$ consist of sandy-silt overbank flood deposits with fine-grained, sub-rounded clasts, these units are interfingered with dark silt-rich layers up to $2 \mathrm{~cm}$ (Figure 11). Subunit 2a consists of course-grained channel gravels that are supported by a sandy-silt matrix. From north to south, this unit grades laterally to subunits $2 \mathrm{~b}$ and 2c (Figure 11), as clast size and abundance decrease and silt content increases to the south. Units 1a - 1c are massive silts that onlap stratigraphy and pinch out to the north (Figure 11). Subunits $1 \mathrm{c}-1 \mathrm{~b}$ are 
massive silts with soil developments. Irregular to prismatic pedogenic structure becomes well-developed with depth. Subunit 1a is a dark brown to black bioturbated silt with some organic material, and A soil horizon development. The uppermost unit is fill material that contains anthropogenic features such as glass fragments, nails, and steel wire, and was emplaced at the trench site during ranching activities.

\subsubsection{Irrigation Ditch Stratigraphy}

The irrigation ditch contains Hennessey Shale bedrock that is in fault contact with unit CT2 (Figure 10C; Appendix D). Unit CT2 is reddish-orange clayey-silt deposit with up to $20 \%$ medium to fine grained gravel clasts. On the down-thrown side of the fault, where unit CT2 has pinched out, the Hennessey Shale is directly overlain by a coarse-medium grained fluvial gravel deposit up to $20 \mathrm{~cm}$ thick. The bedrock and unit CT2 are overlain by a thick tan to brown massive clayey-silt with a moderately developed B horizon soil. The uppermost unit is a dark brown to black, organic rich silt with moderate to well developed A horizon soil. These silts are similar to units $1 \mathrm{a}-1 \mathrm{c}$ in the WM trench. The units documented on the southeast wall of the irrigation ditch are also observed on the northwest wall, but were not logged in detail in this study. 


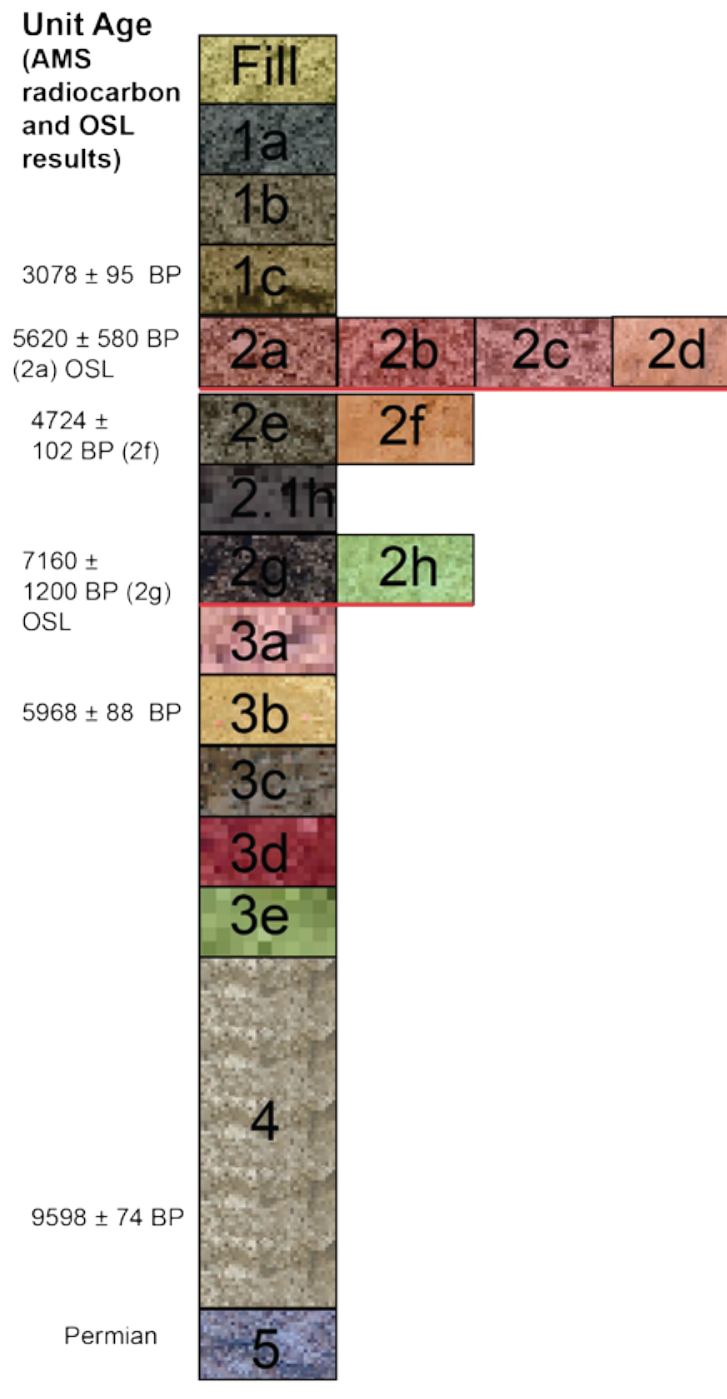
Unit Descriptions
Fill: Modern Human Alteration-Reworked Soil
1a: Silt; dark-reddish grey;organic material; alluvium (A-horizon)
1b: Silt; dark-grey; pedogenic structure; alluvium (B-horizon).
1c: Silt; brown; strong pedogenic structure;
translocated clays, alluvium with modern (Bk horizon)

2a: Medium-coarse gravel with sandy-silt matrix; dark-yellowbrown; fluvial channel deposit.

2b-2c: Silt with coarse gravel; brown; matrix supported; decreasing in clast size and abundance and increasing in content to the south; overbank alluvium.

2d-2f: Sandy-silt; reddish brown to brown; fine-grained, sub-rounded clasts with massive silts; overbank alluvium; $2 \mathrm{~d}$ is Inferred to be correlative in time to $2 \mathrm{a}-2 \mathrm{c}$ ( Channel gravel deposits). $2 e$ and $2 f$ may be older than $2 \mathrm{a}-2 \mathrm{~d}$, and contain massive silts up to $2 \mathrm{~cm}$. $2 \mathrm{e}$ is a dark brown-black silt with soil development up to $20 \mathrm{~cm}$.

2g: Medium gravel; clast-supported, brown matrix; fluvial. $2 \mathrm{~h}$ : Loam with fine-grained clasts; grey/brown to orange mottled color; scarp derived colluvium.

3a-3e: Clayey-silt interbedded with gravel deposits; fine-grained,clast supported gravel, interbedded with silty matrix supported gravels; base of sequence is a $10-20 \mathrm{~cm}$ thick clay. Soil A horizon developed on upper $\sim 1 \mathrm{~cm}$ of each interbed.

4: Silt with sparse gravel; grey to brown; massive; strong blocky pedogenic structure; abundant $\mathrm{CaCO} 3$ nodules; well developed clay films; alluviual deposits with soil development.

5: Permian Hennessey Shale (Bedrock); white to grey.

Figure 11. Stratigraphic column of trench units with summarized descriptions. Detailed unit descriptions are provided in (Appendix C). Radiocarbon and OSL age results for these stratigraphic units are summarized and shown to the left. Sample locations are shown on the trench logs (Figure 12, 13). 


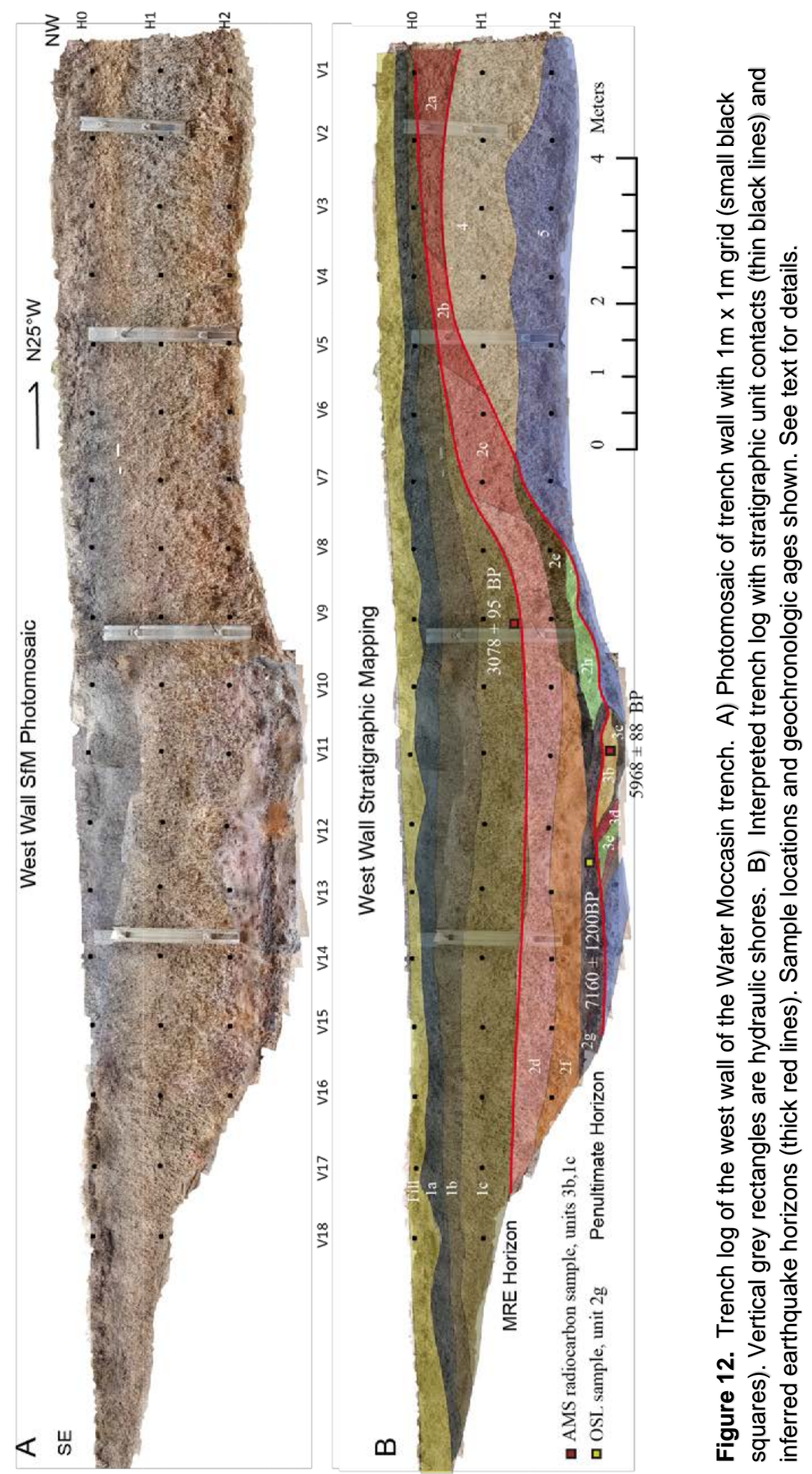




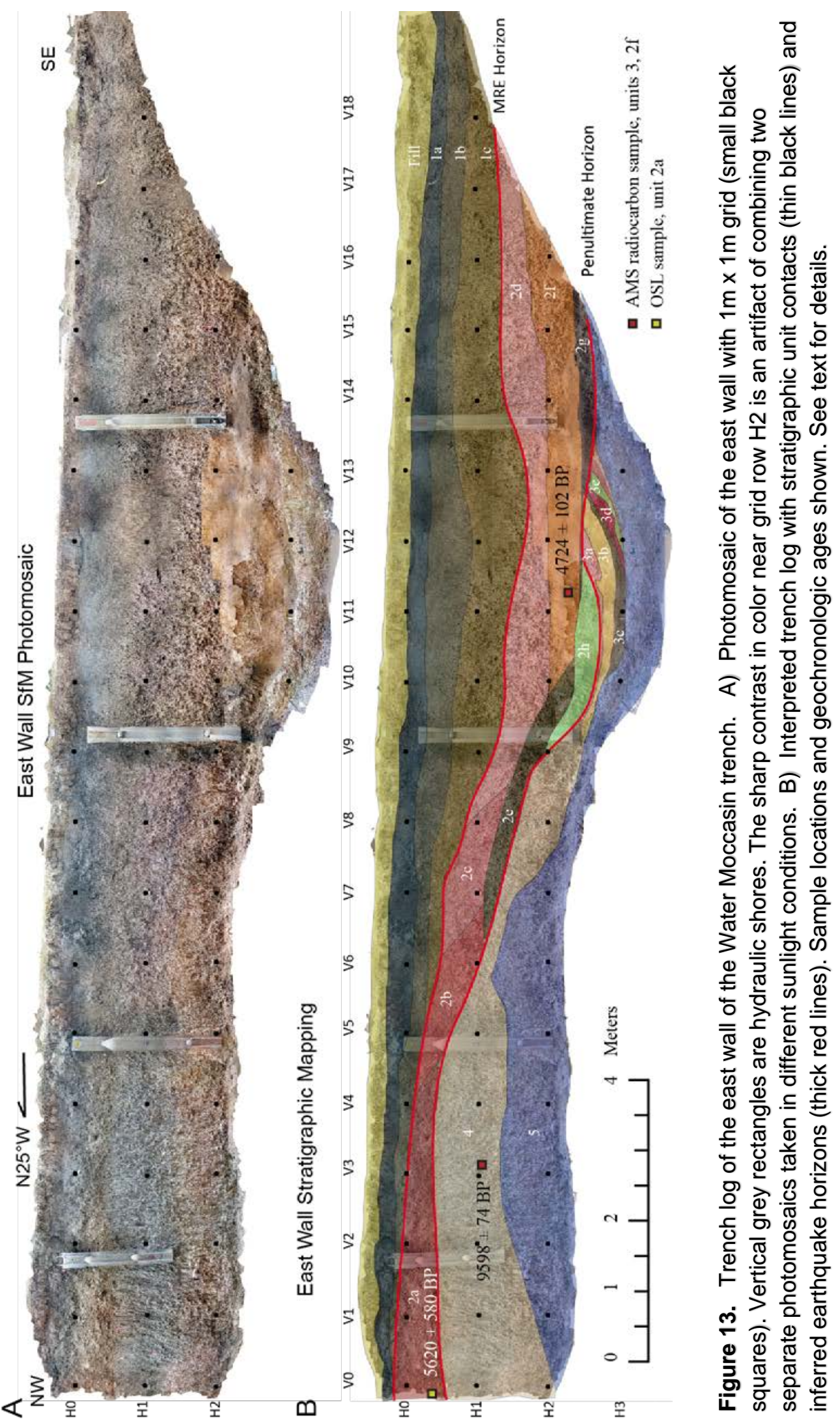




\subsection{Age Results}

\subsubsection{Radiocarbon $\left({ }^{14} C\right)$ Dating}

Trench sediments yielded little organic material for radiocarbon $\left({ }^{14} \mathrm{C}\right)$ dating. The majority of the samples collected from the trench walls believed to be microcharcoal were later determined to be iron oxide nodules after examination under a binocular microscope. Only four of the 11 microcharcoal samples selected from bulk sediment samples sizes survived the pre-treatment process of acid and base rinses. Most samples were of insufficient mass after pre-treatment $(<0.001 \mathrm{~g})$ for radiocarbon analysis. Radiocarbon ages for trench samples were calibrated to the ${ }^{14} \mathrm{C}$ curve (Reimer et al., 2016) and are listed with 2-sigma uncertainty as follows: unit 3, 9680-9520 cal. yrs. BP ( $\pm 2 \sigma)$; unit 4b, 6218-5966 cal. yrs. BP $( \pm 2 \sigma)$; unit 2f, 4832-4624 cal. yrs. BP $( \pm 2 \sigma)$; and the base of unit 1c, 3167-2971 cal. yrs. BP $( \pm 2 \sigma)$ (Table 2).

\subsubsection{Optically Stimulated Luminescence (OSL) Dating}

Two samples were collected from fluvial unit $2 \mathrm{~g}$ and $2 \mathrm{a}$ for OSL analysis. Unit $2 \mathrm{~g}$ yielded a laboratory age of $7160 \pm 1200 \mathrm{BP}$ and unit 2a yielded an age of $5620 \pm 580$ BP, with two sigma uncertainty (Table 3). A common concern with OSL dating in fluvial environments is the potential for partial bleaching (incomplete resetting), resulting in artificially old burial ages (Gray et al., 2015). The preliminary age results were much

older than the ages reported here (see 'central ages' in Table 3), and partial bleaching was suspected. Therefore, abundant (> 50) aliquots were processed by Shannon Mahan at the 
USGS Luminescence Dating Laboratory to identify a more representative age signal from several bleached grains (see ‘minimum age’ in Table 3). 


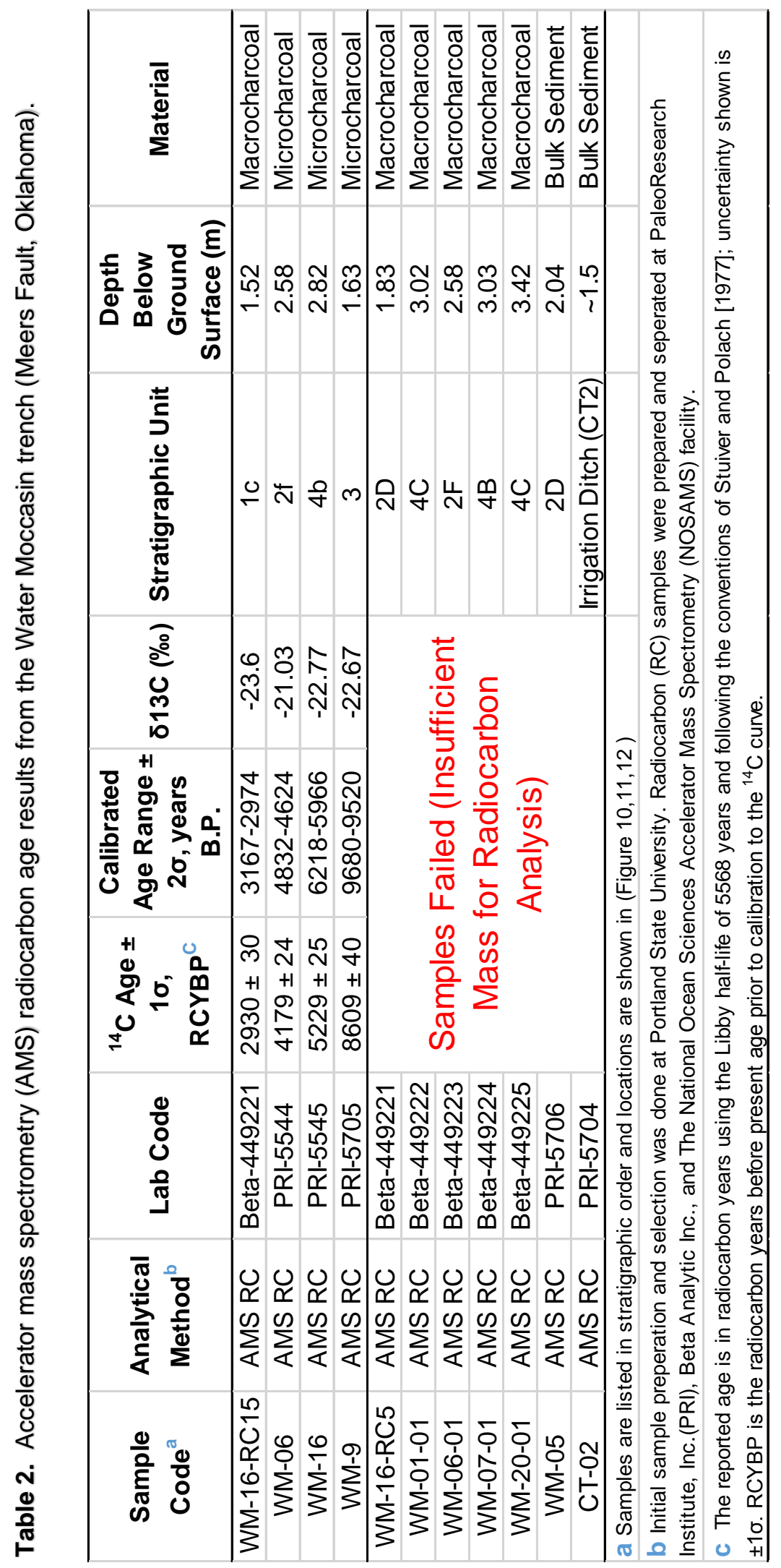




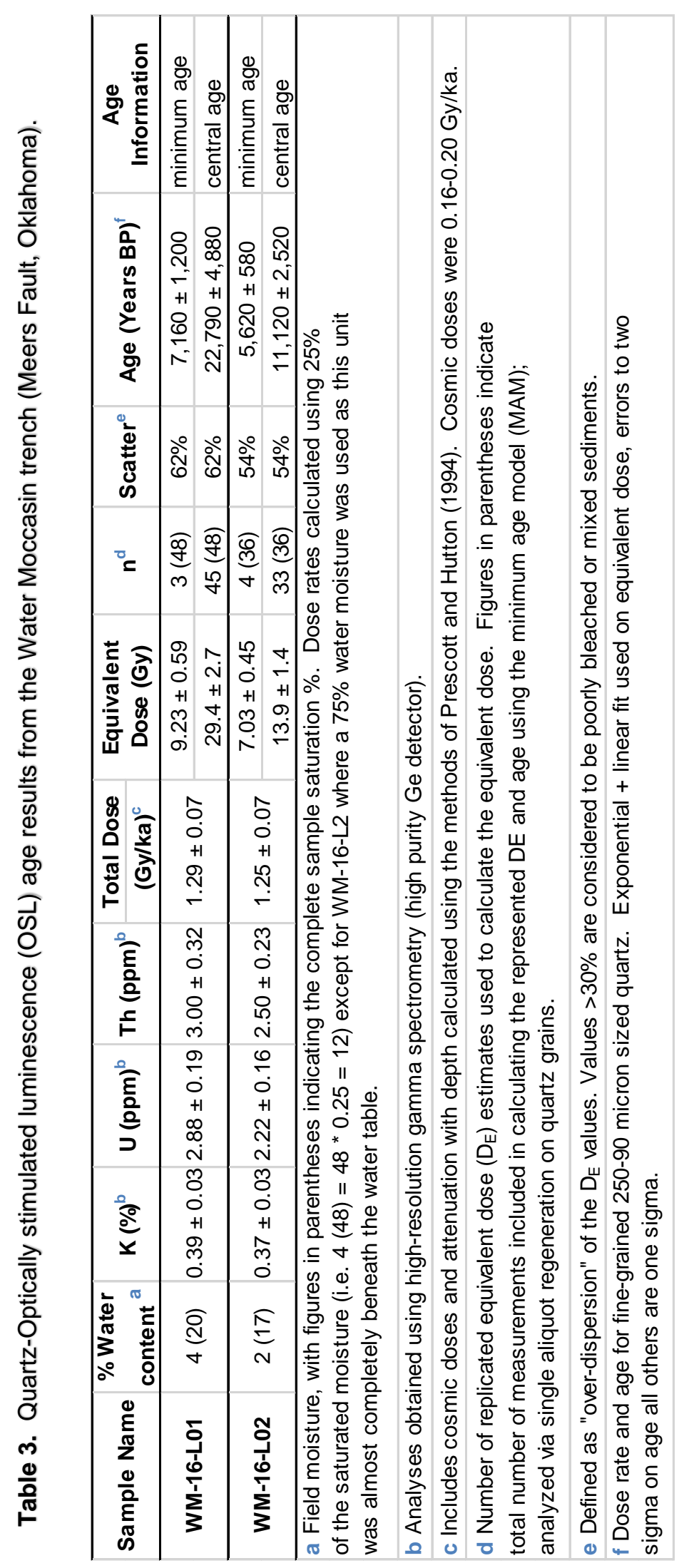




\section{Interpretations}

\subsection{Surface Deformation}

The evidence for Holocene faulting along the $\sim 6.1 \mathrm{~km}$ trace of the Meers Fault identified in this study is very subtle and was previously thought be Quaternary-active (pre-Holocene-active). This previous interpretation was likely due to several factors including: decimeter-scale vertical offsets accommodated over broad zones of surface deformation up to tens of meters wide, monoclinal warping as the primary style of deformation, fluvial erosion and deposition, and anthropogenic alteration of the landscape. I compare topographic scarp profiles for two different lithologies and document relatively wider zones of surface deformation (fold scarps) in the Hennessey Shale where the surface has been deformed by monclinal warping (Figure 14; Table 4). The ratio of vertical separation to the width of surface deformation across the scarp has a mean value of 0.150 for scarps where the fault traverses the Post Oak Conglomerate. The Hennessey Shale Formation accommodates greater widths of deformation, and has a mean ratio of vertical separation to the width of deformation of 0.028 with. The mean and maximum values are an order of magnitude smaller than observed in the Post Oak Conglomerate (Figure 14). Analysis of scarp profiles in the Hennessey Shale show that as vertical surface offset across the fault increases the width of deformation also increase in a nearly linear fashion (Figure 14). In contrast, in the Post Oak Conglomerate as vertical surface offset increases, the width of deformation across the fault appears to not exceed 30 meters. The Hennessey Shale may accommodate a larger width of deformation across the fold scarp due to deformation occurring by a combination of 
brittle fault displacements as well as by broad fold deformation of the surface. In contrast the Post Oak Conglomerate generally experiences brittle failure along a narrow fault zone. Alternatively, the increased width of scarps where the fault traverses the Hennessey Shale may be a function of erosion. The Hennessey Shale is a very highly weathered, weak lithology relative to the competent Post Oak Conglomerate. Erosion and scarp diffusion may contribute to the apparent broad zone of deformation in the weakened, clay-rich shale. The wide, broad wavelength over which vertical displacements are accommodated in the Hennessey Shale may explain why the Meers Fault was previously not considered Holocene-active in the northwest. 


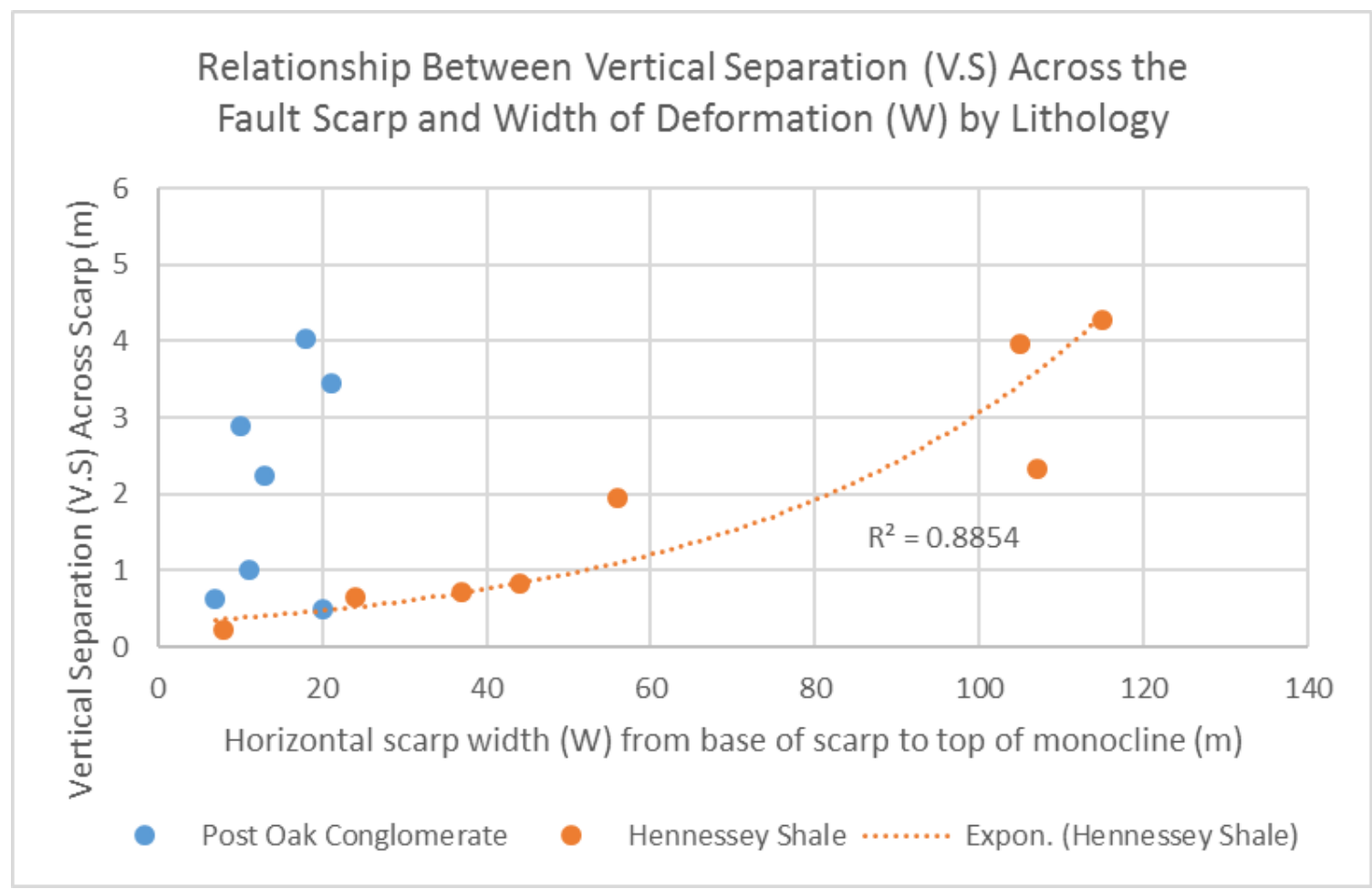

Figure 14. Plot of vertical surface separation along the Meers Fault (V.S) and the width of deformation zone, measured from the base of the scarp to the top of the scarp (W). Orange represents measurements in the Hennessey Shale and blue represents the Post Oak Conglomerate. There is a strong correlation between surface offset and the width of deformation in the Hennessey Shale. The Hennessey Shale accommodates long wavelength deformation in the form of monoclinal warping (folding), whereas the Post Oak Conglomerate deforms via brittle faulting with zones of surface deformation across the fault rarely exceeding $20 \mathrm{~m}$. 


\subsection{Earthquake Evidence}

I document evidence for coseismic up-to the-north monoclinal warping of 1-2 meters of Holocene alluvial deposits and weathered Permian Hennessey Shale bedrock (Figure 12, 13; grid meters V6-V12). The uppermost folded alluvial deposits (unit 2) are onlapped by undeformed, massive silt deposits (unit 1) with moderate soil development. This is in turn overlain by modern fill deposits (unit Fill) (Figures 12, 13). In stream bank exposures within $\sim 1 \mathrm{~km}$ of the trench site, the erosional unconformity cut across Hennessey Shale has a mean dip of $2^{\circ}$ towards the SE with only minor $(<30 \mathrm{~cm})$ erosional undulations observed on the surface of the unit. I identified two Holocene surface rupturing earthquakes within alluvial stratigraphy (Figures 12, 13), and a possible third earlier event. The ground surface during this possible earlier event is an erosional unconformity cut across Permian Hennessey Shale and is loosely constrained by overlying early Holocene deposits. The interpretations of coseismic surface deformation and earthquake horizon determination are provided in Table 5 and I summarize stratigraphic units in Figure 11 and provide detailed unit descriptions in Appendix C.

\subsubsection{Most Recent Earthquake (MRE, E1)}

I map folding of alluvial deposits including: a channel gravel deposit (unit 2a), buried silt overprinted with an A horizon soil (unit 2e), and overbank flood deposits (units 2b-2f). I also identify onlapping to overlapping stratigraphy with soil development (units 1a-1c), and cite all of these as evidence for the MRE event in the WM trench (Figures 12, 13). I document $\sim 0.8 \mathrm{~m}$ of vertical separation along the MRE fold scarp (Figures 12, 13; grid meters V2-V12), which is a minimum value due to erosion on the 
up-thrown side and subsequent deposition at the base of the scarp. The onlapping stratigraphy (units 1a-1c) infill a relatively larger amount of accommodation space on the downthrown, southern side of the fault, that I interpret to have been created by the most recent earthquake. Increased sedimentation on the southern side of the fault brought the ground surface slope closer to the natural floodplain gradient in the basin of $\sim 2^{\circ}$, partially concealing topographic evidence of the fold scarp. In the adjacent irrigation ditch 15 $\mathrm{m}$ east of the trench site, I map a near vertical fault splay $\left(\mathrm{N} 28^{\circ} \mathrm{W}, 86^{\circ} \mathrm{SW}\right)$ which has juxtaposed Permian Hennessey Shale in vertical fault contact with a colluvial wedge deposit and inferred Holocene alluvial deposits (Figure 10, Appendix D). Vertical offset (separation) of the Hennessey Shale bedrock in the irrigation ditch is $\sim 1.5 \mathrm{~m}$ (minimum value). This value is similar to total separation for two events in the WM trench, which may suggest that this splay of the fault was likely activated during both surface folding earthquake events observed in the trench.

\subsubsection{Penultimate Earthquake (E2)}

The penultimate earthquake occurred when unit 4 was at the ground surface on the up-thrown (NE) side of the fault and on-lapping unit 3 was at the ground surface on the downthrown side of the fault. Based on trench mapping, the penultimate event is estimated to have had $\sim 0.8 \mathrm{~m}$ of vertical offset (minimum) across the fold scarp (Figures 12, 13). The penultimate earthquake surface in the WM trench is vertically displaced by $\sim 1.6 \mathrm{~m}$ across the fault scarp, with $\sim 0.8 \mathrm{~m}$ of this displacement due to the MRE event, described above. The up-thrown, northern side of the penultimate fold scarp consists of alluvial silt (unit 4). This unit was deformed by the penultimate earthquake, and was 
folded up on the NE side of the trench and collapsed and was eroded and deposited as scarp-derived colluvium (unit 2h) onto the penultimate earthquake horizon (Figures 12, 13). On the downthrown, southern side of the fold scarp, unit 3 , interbedded low-energy ponded alluvial deposits of uniform thickness, and high energy fluvial gravel deposits, are folded. These inclined beds are truncated across a sharp, sub-horizontal erosional unconformity (see V12-V13 in Figures 11 and 12). Unit 3 strata were likely tilted downto-the-north via folding during the penultimate earthquake. Alternatively, sub-units of 4 may have been deposited in their $\sim 40^{\circ}$-inclined orientation as forset beds in a small stream channel that was focused at the toe of a pre-existing fold scarp.

\subsubsection{Ante-Penultimate Earthquake (E3)}

The Permian Hennessey Shale bedrock has a minor topographic low of $\sim 20 \mathrm{~cm}$ on the downthrown side of the fold. This low was infilled by an on-lapping sequence of fluvial sediments, units 3a-3e (Figures 12 and 13; grid V10-V13). I interpret existing vertical relief on the Hennessey Shale ground surface that was infilled by fluvial sediments with a $20 \mathrm{~cm}$ thick buried soil developed at the base of them. I propose the topographic low on the Hennessey Shale that coincides with the location of the base of the fold scarp was formed by an earlier surface deforming earthquake that created a southeast facing fold scarp (see panel 'A' in Figure 15). These deposits and the topographic low are only a few meters in length, and are only observed at the toe of the monocline. These types of low energy, fine-grained onlapping deposits are not observed elsewhere else in the trench. Alternatively, this topographic low may have been created 
from natural erosion over time of the surface, the relief of $20 \mathrm{~cm}$, is within the range of erosional relief observed elsewhere on the Hennessey Shale.

Table 5. Summary of earthquake evidence documented in the Water Moccasin trench (Meers Fault, OK) and earthquake timing constrained by the Oxcal Bayesian statistical model shown in Figure 16.

\begin{tabular}{|c|c|c|c|}
\hline Event & $\begin{array}{l}\text { Event } \\
\text { Horizon }\end{array}$ & Earthquake Evidence & $\begin{array}{c}\text { Modeled } \\
\text { Event } \\
\text { Timing }(2 \sigma)\end{array}$ \\
\hline \multirow[t]{4}{*}{ MRE (E1) } & \multirow{4}{*}{$2 \mathrm{~A}, 2 \mathrm{D}$} & 1. Monoclinal folding of units $2 a-2 f$ & \multirow{4}{*}{$\begin{array}{l}\quad 4702-3108 \\
\text { cal. years BP }\end{array}$} \\
\hline & & $\begin{array}{l}\text { 2. Onlapping to overlapping massive silts that have soil } \\
\text { development (units } 1 \mathrm{a}-1 \mathrm{c} \text { ) infill relief across the scarp. }\end{array}$ & \\
\hline & & $\begin{array}{l}\text { 3. Uplift of channel gravel depoists (unit } 2 a \text { ) above overbank } \\
\text { flood deposits. }\end{array}$ & \\
\hline & & $\begin{array}{l}\text { 4. Faulting in the irrigation ditch: faulted gravels above } \\
\text { Hennessey Shale are believed to be similar to unit } 2 g \text { in the } \\
\text { WM trench. Scarp derived colluvium is inferred to be } \\
\text { Holocene here. }\end{array}$ & \\
\hline \multirow[t]{3}{*}{ Penultimate (E2) } & \multirow{3}{*}{$3,4 \mathrm{~A}, 4 \mathrm{~B}$} & $\begin{array}{l}\text { 1. Erosion of the fault scarp (unit } 4 \text { ) and deposition of a } \\
\text { colluvial wedge (unit } 2 \mathrm{~h} \text { ). }\end{array}$ & \multirow{3}{*}{$\begin{array}{c}6152-5550 \\
\text { cal. years BP }\end{array}$} \\
\hline & & $\begin{array}{l}\text { 2. Fluvial deposits are eroded and truncated by a high } \\
\text { energy fluvial deposit (unit } 2 \mathrm{~g} \text { ) that is following the } \\
\text { topographic low across the scarp created by the penultimate } \\
\text { earthquake. }\end{array}$ & \\
\hline & & $\begin{array}{l}\text { 3. Fluvial deposits (Unit } 3 \text { ) are folded and tilted, these are } \\
\text { more deformed than overlying strata. }\end{array}$ & \\
\hline $\begin{array}{c}\text { Ante- } \\
\text { Penultimate } \\
\text { (E3?) }\end{array}$ & $\begin{array}{l}\text { Erosional } \\
\text { Unconformity } \\
\text { cut across } \\
\text { Hennessey } \\
\text { Shale }\end{array}$ & $\begin{array}{l}\text { 1. A topographic low may have existed at the base of the } \\
\text { modern escarpment and localized the deposition of unit } 3 \text {. } \\
\text { This depression is coincident with the fold zone, and may } \\
\text { have been created tectonically or simply by erosion. }\end{array}$ & $\begin{array}{c}\text { 9598- cal. } \\
\text { years BP - } \\
\text { Permian }\end{array}$ \\
\hline
\end{tabular}

\subsection{Trench Retro-Deformation}

I retro-deformed trench stratigraphy to model the stages of fault-related surface folding, deposition, and erosion of trench sediments and show this reconstruction in Figure 15 and Table 5. In this model I account for surface folding earthquake 
deformation, while maintaining unit thickness in strata located below the paleo-ground surface (erosional surface). I also maintain surface line length for earthquake horizons and key stratigraphic units as an independent measure of total shortening/lengthening in the retro-deformation. I remove vertical separation from earthquake horizons in a stepwise fashion conserving unit line lengths in the retro-deformation. The retro-deformation shows major stratigraphic units at each earthquake horizon, major erosional events, and deposition. Below, I summarize the sequence of events in my preferred retrodeformation model, including pre-historic earthquake evidence and mapped trench stratigraphy.

Figure 15 panel 'A' shows Permian Hennessey Shale as the ground surface at the WM trench site. Figure 15 panel 'I' shows the final unit geometry observed in the 2016 trench exposures. The trench log for the WM East wall is shown at the bottom of the figure with the same unit geometry shown in part I. Note that in Figure 15 panel 'A', the Hennessey Shale had a topographic low at the base of the inferred fault scarp south of the fault (Figure 15 A). Massive silt, unit 4, blanketed the Hennessey Shale (Figure 15 B), this is a thick unit on the up-thrown side of the fold scarp. We interpret this unit to be laid down nearly uniformly across the site and subsequently eroded from the down-thrown side of the fault along the southern end of the trench. Unit 4 may have been eroded by a channelizing surface flow along the base of the monocline. Following this, Unit 3, a sequence of ponded alluvial and high-energy gravel interbeds were deposited in the swale shown in panels 'A-C', infilling relief where Unit 4 was scoured out. Our age results 
show the lower portion of the massive silt Unit 4 (Figures 11, 12, 13), is older than the inclined fluvial deposits (Figure 15).

Figure 15 panel 'D' shows major stratigraphic units involved in the penultimate earthquake. The penultimate earthquake event generated a minimum up-to-the-north vertical surface offset of $\sim 0.8 \mathrm{~m}$, forming a southwest-facing fold scarp within unit 4 (Figure 15, D). On the south, down-thrown side of the fault, the inclined fluvial deposits of unit 3 were eroded and truncated by a thick (up to $30 \mathrm{~cm}$ ) gravel deposit unit $2 \mathrm{~g}$ gravel (Figure 15, E). Unit 2g was deposited by a high-energy fluvial system that was focused along the topographic low (toe of fold scarp) generated by the penultimate earthquake. Synchronously, erosion and gravity driven failure of the fault scarp occurred and deposited a colluvial wedge (unit 2h) at the base of the escarpment (Figure 15, E).

Following deposition of scarp derived colluvial unit 2h, a package of fluvial overbank flood deposits, channel gravels, and massive silt with several cm of soil development onlapped the fault scarp (Figure 15, F; unit 2f). Fold scarp relief across the site was smoothed by both erosion of the scarp and subsequent in-filling deposition, the ground surface became stable marked by soil development across the ground surface (Figure 15 G; Figures 12, 13; unit 2e; grid V6.5-v10.5). I document a thick soil (unit 2e) developed on Unit 4 where it was the ground surface north of the fault, and several thin soil profiles within the infilling Unit 2 sequence that merge with the soil developed on Unit 3 (Figure 15 F). To the south, at the base of the gentle fold scarp, the Unit 2e soil transitions into multiple thin dark brown to black soil horizons developed on interbedded silty-sand ephemeral flood deposits (Figure 12, 13; unit 2f). Subsequently, Figure 15 
panel 'G' shows deposition of fluvial units 2a-2e. Unit 2a is a coarse channel gravel deposited in the northern end of the trench (Figure 12,13; unit 2a; grid V0-V2). I observe increased fluvial incision on the up-thrown block of the fault. Similar incision and erosion may have created an erosional undulation that controlled the location of the coarse channel gravel deposit (unit 2a). Units 2b-2d and 2f are interbedded overbank fluvial flood deposits deposited from ephemeral flood events by the stream that deposited unit 2a at the north end of the trench (Figure 12,13). The unit 2 sequence on-laps the scarp infilling vertical relief on the south and overlaps the scarp, bringing the overall surface gradient back to a $2^{\circ}$ slope to the southwest (Figure $15 \mathrm{G}$ ).

Unit 2 was the ground surface during the MRE (Figure $15 \mathrm{H}$ ). The MRE event generated a minimum vertical displacement of $\sim 0.82 \mathrm{~m}$ and uplifted the channel gravel deposits of unit 2a on the north, and folded fluvial units 2b-2f on the south (Figure $15 \mathrm{G}$ ). A buried soil, unit 2e has uniform thickness and is folded with the same amount of vertical displacement across the fold. Undeformed silt deposits unit 1a-1c onlap and overlap the fold scarp (Figure 12, 13; unit 1), these units are thickened on the downthrown side of the fault (Figure 15, H). A sample collected from the base of these units was radiometrically dated and yields a minimum age constraint on the MRE event. The unit 1 sequence infills vertical relief formed by the MRE and returns the ground surface gradient up to the locally measured, gentle $\sim 2^{\circ}$ slope to the SE. 
North

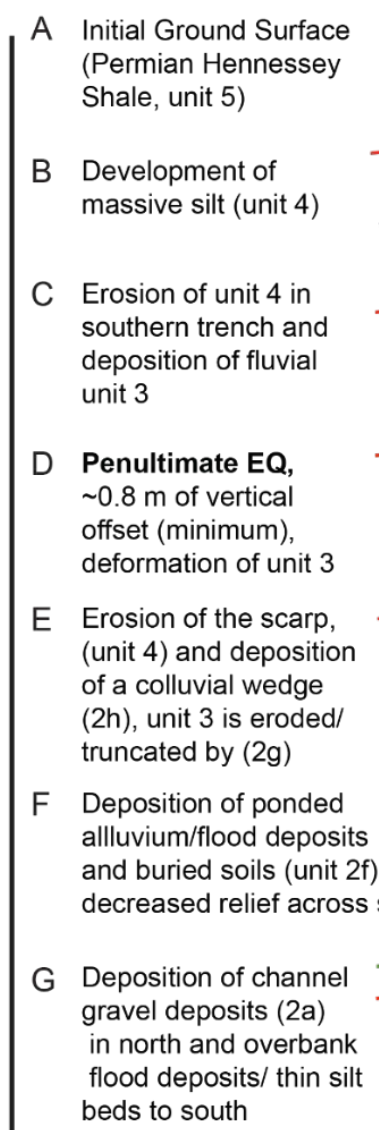

H MRE Event, $\sim 0.8 \mathrm{~m}$ of displacment uplift of channel gravels, folding of units $2 b-2 f$

I Undeformed silt (unit 1) onlaps and overlaps the scap and deformed strata.
Water Moccasin trench (east wall)

South

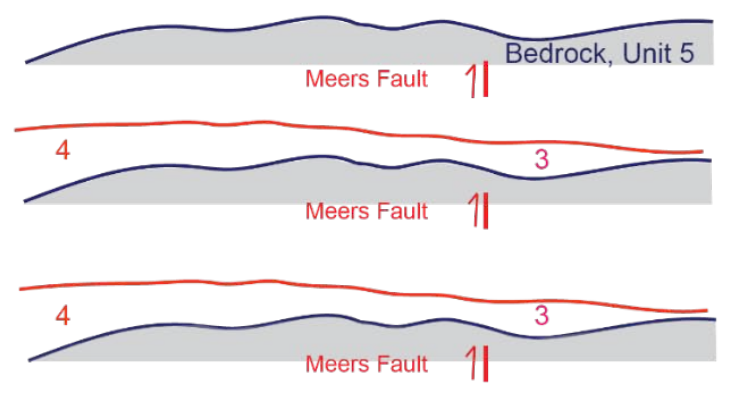

Note: The

orange line is the penultimate EQ horizon and

the green line is the MRE

horizon, these are not always stratigraphic contacts.
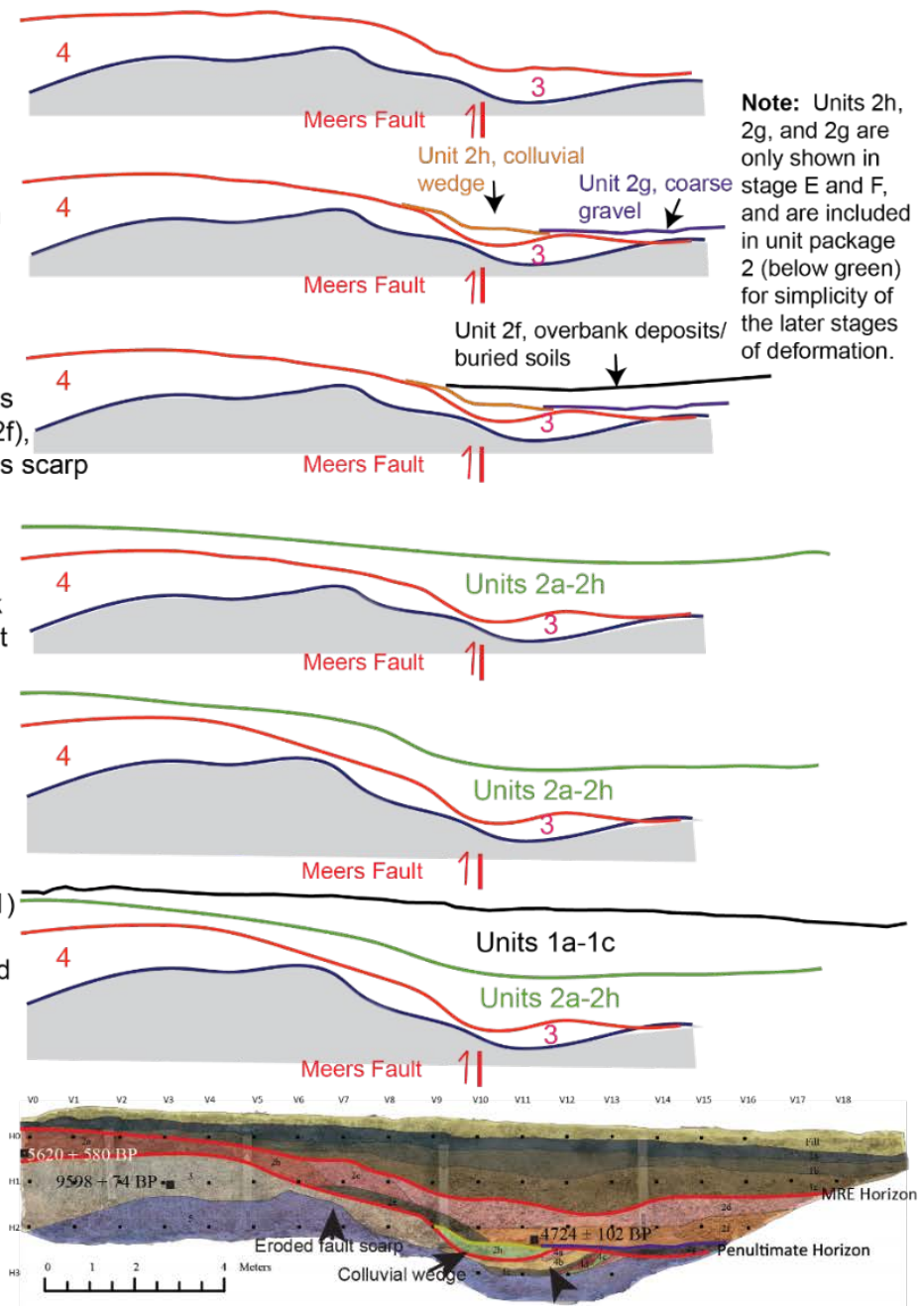

Figure 15. Schematic reconstruction of event history for the east wall of the Water Moccasin trench (Meers Fault, OK). The model incrementally restores progressive deformation and also illustrates the erosion and deposition of Holocene units across the Meers fold scarp at the Water Moccasin site. Oldest event is at the top; youngest is at the bottom. The lowest image is the stratigraphy and geometric relations mapped in the east wall of the trench. Contacts were retrodeformed by maintaining unit thickness for buried stratigraphy below each iterative ground 
surface. Surface line length is maintained as an independent measure of total shortening in model. Each iterative step is explained on the left of the schematic diagram. Earthquake evidence is summarized in Table 5 .

\subsection{Earthquake Timing}

My OxCal Bayesian statistical model (Bronk-Ramsey, 2009) uses stratigraphic ordering information to constrain the age of stratigraphic units and timing of surface deforming earthquakes interpreted from trench data (Figure 16; after Lienkamper and Bronk-Ramsey, 2009). Due to the loss of small samples that were dissolved during pretreatment, we were only able to bracket the MRE with one maximum and one minimum limiting radiocarbon age. The interpreted MRE is thus loosely constrained to have ruptured between $4702 \mathrm{BP}$ and $3108 \mathrm{BP}$ ( $1 \sigma$ uncertainty). Both radiocarbon and OSL ages helped constrain the interpreted penultimate earthquake event, which occurred between $6152 \mathrm{BP}$ and $5550 \mathrm{BP}$ (1 $\sigma$ uncertainty).

Table 6. Summary of OxCal statistical model results.

\begin{tabular}{ccccc}
\hline \multicolumn{5}{c}{ OxCal Modeling Results } \\
\hline Sample/Earthquake & Unit & $\begin{array}{c}\text { Unmodeled (years BP) } \\
(95.4 \%)\end{array}$ & $\begin{array}{c}\text { Modeled (years BP) } \\
(95.4 \%)\end{array}$ & A $^{*}$ \\
\hline WM_16_RC15 & 1c & $3169-2974$ & $3168-2975$ & 99.6 \\
MRE (E1) & & & $4702-3108$ & \\
WM_B6 & 2f & $4831-4625$ & $4832-4626$ & 100 \\
WM_16_OSL2 & 2a & $6200-5040$ & $5844-4997$ & 100.9 \\
WM_17_OSL1 & 2g & $8360-5960$ & $6035-5315$ & 9.1 \\
Penultimate (E2) & & & $6152-5550$ & \\
WM_B16 & 4b & $6170-5919$ & $6175-5921$ & 90.8 \\
WM_B9 & 3 & $9672-9524$ & $9670-9522$ & 101.3 \\
\hline * A is the individual agreement index, which indicates how well each sample agrees with the \\
overlying and underlying stratigraphic age results.
\end{tabular}


The radiocarbon age results have relatively small 1-sigma errors associated with them and are in strong agreement with the OxCal statistical model. The OSL results have larger 1-sigma uncertainty (Table 3). It is possible that some quartz grains are partially bleached, which may allow the grains to indicate ages that are significantly older than their burial ages. The age of sample WM_16_OSL1 (8360-5960 yrs. BP) barely overlaps with ages from underlying and overlying units, and has an OxCal individual agreement index value of 9.1 (Table 6). This sample is from a fluvial gravel deposit (unit 2g) that formed at the base of the penultimate earthquake scarp. I interpret this unit to have been deposited in a high-energy fluvial environment, where quartz grains may have had short transport times and may not have had their luminescence signal completely reset. My OxCal modeling was able to significantly trim the prior age distribution of this sample to a posterior age distribution that was useful for bracketing Holocene earthquakes (Figure 16). Sample WM_16_OSL2 is from the channel gravel deposit (unit 2a) and its age may also be older than its burial due to the presence of partially bleached grains. This age for unit 2a was only modified slightly by my OxCal age modeling (Figure 16) and was also useful in bracketing the timing of the two most recent Holocene earthquakes. 


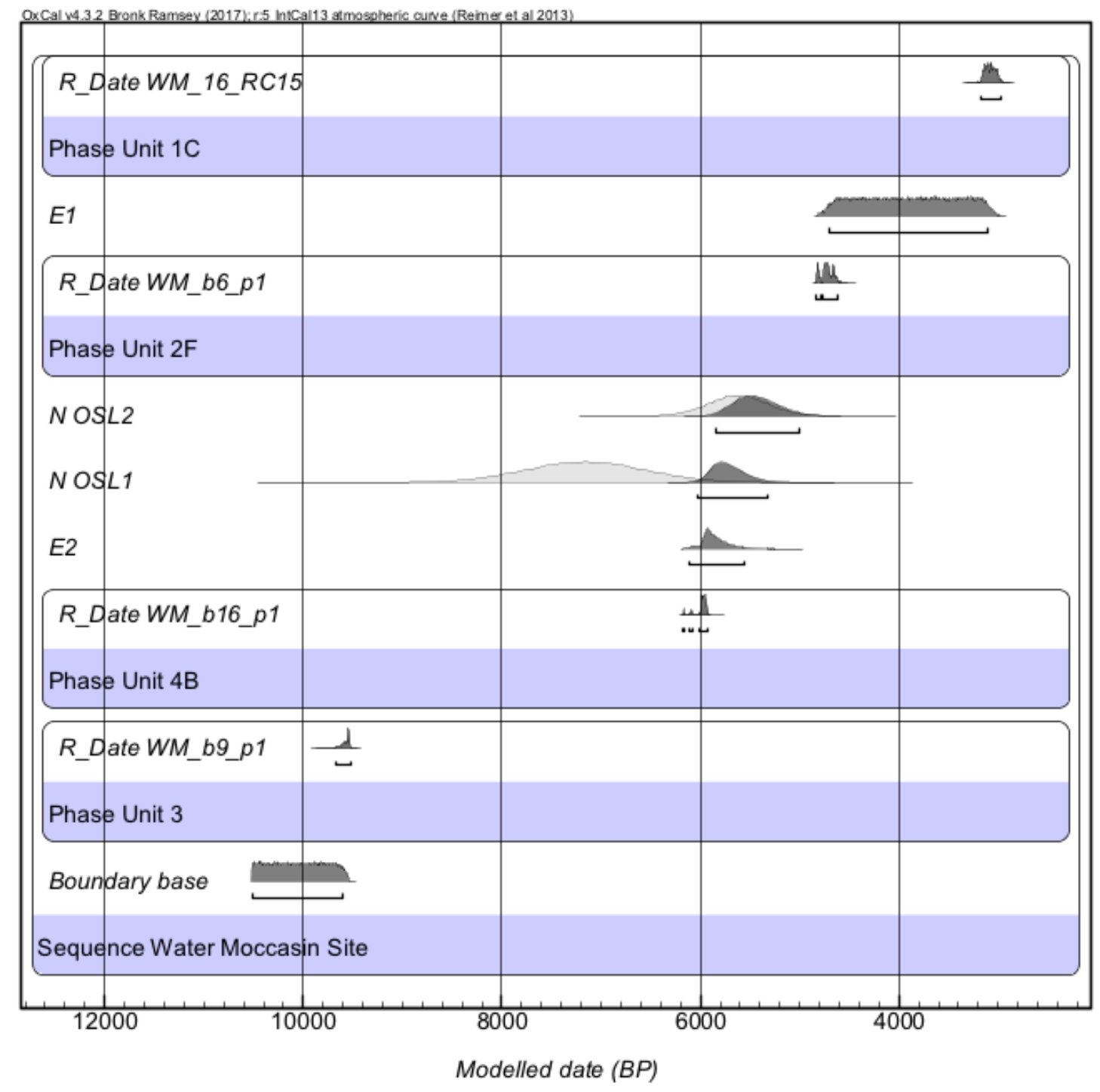

Figure 16. Oxcal Bayesian statistical model of OSL and calibrated ${ }^{14} \mathrm{C}$ ages modeled to constrain the ages of Holocene earthquakes (E1 and E2) observed in the Water Moccasin trench (Meers Fault, Oklahoma). Model results are based on stratigraphic ordering of trench units. Light gray probability distribution functions (pdfs) are 'prior' distributions, dark gray pdf's are 'posterior' distributions constrained by ordering information (see Bronk-Ramsey (2009) and Lienkaemper and Brock-Ramsey, 2009 for details of this method). Earthquake timing pdf's for E1 and E2 are calculated from the modeled posterior distributions. 


\section{Conclusions}

Using lidar, balloon-based SfM, and historical aerial photographic data I characterize subtle geomorphic evidence of surface faulting and folding along the northwestern section of the Meers Fault. This, coupled with age dates from deformed alluvial stratigraphy from the Water Moccasin trench lead me to conclude that the length of the Holocene-active Meers Fault should be increased $\sim 6.1 \mathrm{~km}$ to the northwest of the currently mapped Holocene-active trace. I document linear escarpments, closed depressions on the downthrown block, and increased channel incision on the up-thrown block as additional geomorphic evidence for recent fault activity. I document long wavelength deformation (monoclinal folding) of the surface where the fault traverses Permian Hennessey Shale bedrock, and show that this lithology accommodates a more broad zone of deformation than the Permian Post Oak Conglomerate. Using faultperpendicular topographic profiles, I show that the northwest section of the Meers Fault has decimeter surface offsets across the fault and that surface offset decreases towards the NW and SE tips of the $\sim 43$ km-long Meers Fault. My analysis also indicates that balloon-based SfM is able to detect decimeter-scale fault offsets on an intraplate fault in a grassland environment, though these datasets have higher uncertainty than airborne lidar. I also document a near linear correlation of mean flight altitude and achievable resolution using balloon-based SfM.

I provide evidence for two Holocene surface folding earthquakes in the Water Moccasin paleoseismic trench, with the MRE event loosely constrained between 4702 BP and $3108 \mathrm{BP}$ (1 $\sigma$ uncertainty), and the penultimate event having occurred between 6152 
BP and 5550 BP (1 $\sigma$ uncertainty). A younger event, ca. 1200 BP, documented by Crone and Luza (1990) and Kelson and Swan (1990) as the MRE event along the southeastern section of the Meers Fault was not identified in the Water Moccasin trench of this study. This 1200 BP surface rupturing earthquake may not have propagated to the northwest as far as the Water Moccasin trench, providing crucial constraints on the length of the most recent surface-rupturing earthquake on the Meers Fault. The MRE event document in the Water Moccasin trench (4702-3108 BP) may correlate with an older earthquake, ca. 2900-3400 BP (the penultimate event on the southeast section of the Meers Fault), documented by Crone and Luza (1990) and Kelson and Swan (1990). This indicates that some earthquakes may rupture the entire $43 \mathrm{~km}$ length of the Holocene-active Meers Fault. The relatively longer duration ( 3100 to 4700 years) since the most recent earthquake along the northwest section of the Meers Fault may contribute to its subtle geomorphic fault expression there. Additionally, if the southeast section MRE is not present in the northwest this could indicate bimodal rupture along that fault, with some earthquakes rupturing the entire 43 km length of the Meers Fault and others rupturing only the southeast $\sim 37 \mathrm{~km}$ of the fault. Alternatively, slip on the northwest section of the fault could have been small in the 1200 BP earthquake observed on the southeastern section of the fault and did not produce surface deformation on the northwest section of the fault that would produce an unconformity detectable in a paleoseismic trench.

I extend the Holocene-active length of the Meers Fault from 37 km to $43 \mathrm{~km}$. The length of surface rupture has been empirically shown to be directly correlative with 
the maximum magnitude of an earthquake (Wells and Coppersmith, 1994). Using equation 1, from Wells and Coppersmith (1994),

$$
M=a+b * \log (S R L)
$$

where $\mathrm{M}$ is earthquake magnitude, a and $\mathrm{b}$ are regression coefficients based on observed earthquake magnitudes and surface rupture lengths, and SRL is the surface rupture length, I calculate the possible magnitude of a surface rupturing earthquake along the $\sim 43$ km-long Holocene-active Meers Fault. For pure strike-slip motion along the fault I calculate a magnitude of $\mathrm{M}=7.0$, and for pure reverse displacement I obtain a value of $M=6.99$, these values vary due to different regression coefficients (a, b) for different styles of faulting. This analysis provides further evidence that the Meers Fault is a considerable seismic hazard for the Central and Eastern United States (CEUS). 


\section{Future Work}

The Water Moccasin paleoseismic trench provides a single data point for Holocene surface deforming earthquakes along the mapped northwestern section of the Meers Fault. Additional paleoseismic trench studies should be conducted in this region, particularly adjacent to the irrigation ditch (Figure 10). Trenches could also provide insight farther to the southeast along the scarp near my balloon-based SfM 'B2' dataset and topographic profile (Figure $7 \mathrm{E}$ ) to better understand the broad fold deformation along this section of the Meers Fault. Additionally, due to the lack of organic material, more OSL samples for dating of trench sediments near the Water Moccasin trench may better constrain surface rupturing earthquake horizons. Fault parallel trenches excavated at the Water Moccasin site might be useful for estimating lateral displacement from the identified earthquake events. Buried channels identified in the WM trench (units 2a and 2g) may be used as piercing points to estimate this displacement. Considering the decimeter-scale surface offsets detected in the northwest as well as the southeast tips of the Meers Fault, the furthest southeast mapped extent of the Meers Fault may be a subject for future studies. 


\section{References}

Bain, B. Y. H. F. (1900). Geology of the Wichita Mountains. Bulletin of the Geological Society of America, 11(127), 127-144.

Baker, E. M., \& Holland, A. A. (2013). Probabilistic Seismic Hazard Assessment of the Meers Fault, Southwestern Oklahoma : Modeling and Uncertainties, Oklahoma Geological Survey Special Publication SP2013-02.

Beauchamp, W., Barazangi, M., Demnati, A., \& El Alji, M. (1996). Intracontinental rifting and inversion: Missour basin and Atlas mountains, Morocco. AAPG Bulletin, 80(9), 1459-1482. http://doi.org/10.1306/64ED9A60-1724-11D78645000102C1865D

Bemis, S., Micklethwaite, S., Turner, D., James, M. R., Akciz, S., Thiele, S., \& Bangash, H. A. (2014). Ground-based and UAV-Based photogrammetry: A multi-scale, highresolution mapping tool for Structural Geology and Paleoseismology. Journal of Structural Geology, 69, 163-178. http://doi.org/10.1016/j.jsg.2014.10.007

Bronk-Ramsey, C. (1995). Radiocarbon Calibration and Analysis of Stratigraphy: the OxCal Program. Radiocarbon, 37(2), 425-430. http://doi.org/10.2458/rc.v37i2.1690

Bronk-Ramsey, C., 2009, Dealing with Outliers and Offsets in Radiocarbon Dating: Radiocarbon, v. 51, p. 1023-1045, doi: 10.1017/s0033822200034093.

Budnik, R. T. (1986). Left-lateral intraplate deformation along the ancestral rocky mountains: Implications for late paleozoic plate motions. Tectonophysics, 132(1-3), 195-214. http://doi.org/10.1016/0040-1951(86)90032-6

Budnik, R. T. (1987). Late Miocene reactivation of Ancestral Rocky Mountain structures in the Texas Panhandle: A response to Basin and Range extension. Geology, 15(February), 163-166.

Caskey, S., 1995, Geometric relations of dip slip to a faulted ground surface: new nomograms for estimating components of fault displacement: Journal of Structural Geology, v. 17, p. 1197-1202, doi: 10.1016/0191-8141(95)00023-7.

Cetin, H. (1991). The Northwest Extension of the Meers Fault in Southwestern Oklahoma. Texas A\&M University.

Cetin, H. (1998). Near-surface folding along an active fault: seismic or aseismic? Tectonophysics, 292(3-4), 279-291. http://doi.org/10.1016/S0040-1951(98)00074-2

Cetin, H. (2003). Comment on "Known and suggested Quaternary faulting in the midcontinent United States” by Russell L. Wheeler and Anthony Crone. Engineering Geology, 69(1-2), 193-210. http://doi.org/10.1016/S00137952(02)00270-3 
Crone, A. J., Luza, K. V, \& Geological, O. (1990). Style and timing of Holocene surface faulting on the Meers Fault, southwestern Oklahoma. Geological Society of America Bulletin, 102(1), 1-17. http://doi.org/10.1130/0016-7606(1990)102<0001

Crone, A. J., \& Wheeler, R. L. (2000). Data for Quaternary faults , liquefaction features, and possible tectonic features in the Central and Eastern United States, east of the Rocky Mountain front By Class A Features : UGSG OFR-00260, Prepared as part of the USGS NEHRP Map of Quaternary Faul. Area.

Donovan, R.N., Gilbert, M.C., Luza, K.V., Marchini, W.R.D. Sanderson, D. J. (1983). Possible Quaternary Movement on the Meers Fault, southwestern Oklahoma. Oklahoma Geology Notes, 43, 124-133.

Feinstein, S. (1981). Subsidence and Thermal History of Southern Oklahoma Aulacogen: Implications for Petroleum Exploration. AAPG Bulletin, 65(12), 2521-2533.

Frankel, K. L., Dolan, J. F., Finkel, R. C., Owen, L. a., \& Hoeft, J. S. (2007). Spatial variations in slip rate along the Death Valley-Fish Lake Valley fault system determined from LiDAR topographic data and cosmogenic 10Be geochronology. Geophysical Research Letters, 34, 1-6. http://doi.org/10.1029/2007GL030549

Gilbert, M. C. (1983a). The Meers Fault-Unusual Aspects and Possible Tectonic Consequences. Geological Society of America Abstracts with Programs, 18, 1.

Gilbert, M. C. (1983b). The Meers Fault of Southwestern Oklahoma-Evidence for Possible Strong Quaternary Seismicity in the Midcontinent [abs]. EOS, Transactions of the American Geophysical Union, 64, 313.

Gray, H. J., Mahan, S. A., Rittenour, T., Nelson, M. S., \& Survey, U. S. G. (2014). GUIDE TO LUMINESCENCE DATING TECHNIQUES AND THEIR APPLICATION FOR Field Collection : Site Considerations.

Ham, E.W, Denison, R.E, Merritt, C. . (1965). Basement Rocks and Structural Evolution of Southern Oklahoma-A Summary. AAPG Bulletin, 49(7), 927-934.

Ham, W. E. (1959). Field Trip to Wichita Mountain Area, Southwestern Oklahoma, Held in Conjunction with the Eighth National Clay Conference, October 11, 1959. Clays and Clay Minerals, 8(1), 1-10. http://doi.org/10.1346/CCMN.1959.0080103

Hanson, R. E., Puckett, R. E., Keller, G. R., Brueseke, M. E., Bulen, C. L., Mertzman, S. A., ... Mccleery, D. A. (2013). Lithos Intraplate magmatism related to opening of the southern Iapetus Ocean : Cambrian Wichita igneous province in the Southern Oklahoma rift zone. LITHOS, 174, 57-70. http://doi.org/10.1016/j.lithos.2012.06.003

Harding, D.J, Berghoff, G. . (2000). Fault Scarp Detection Beneath Dense Vegetation Cover: Airborne Lidar Mapping of the Seattle Fault Zone, Bainbridge Island, Washington State. 
Harlton, B. H. (1951). Faults in Sedimentary Part of Wichita Mountains of Oklahoma. AAPG Bulletin, 35(5), 988-999.

Hoffman, P., Dewey J.F., Burke, K. (1974). Aulacogens and their Genetic Relation to Geosynclines, with a Proterozoic Example from Great Slave Lake, Canada. AAPG Bulletin.

Holland, A. (2013). Optimal Fault Orientations within Oklahoma. Seismological Research Letters, 84(5), 876-890. http://doi.org/10.1785/0220120153

James, M. R., Robson, S., Centre, L. E., \& Engineering, G. (2014). Mitigating systematic error in topographic models derived from UAV and ground-based image networks, 1420(June), 1413-1420. http://doi.org/10.1002/esp.3609

Johnson, K., Nissen, E., Saripalli, S., Arrowsmith, J. R., Mcgarey, P., Williams, P., \& Blisniuk, K. (2014). Rapid mapping of ultrafi ne fault zone topography with structure from motion, (5), 1-18. http://doi.org/10.1130/GES01017.1

Jones-Cecil, M. (1995). Structural controls of Holocene reactivation of the Meers Fault, southwestern Oklahoma, from magnetic studies. Geological Society of America Bulletin, 107(1), 98-112. http://doi.org/10.1130/00167606(1995)107<0098:SCOHRO>2.3.CO;2

Keller, G.R, Baldridge, W. S. (2006). The Southern Oklahoma Aulacogen (Vol. 25). Elsevier Ltd. http://doi.org/10.1016/SO419-0254(06)80020-0

Keller, G. R., Lidiak, E. G., Hinze, W. J., \& Braile, L. W. (1983). The role of rifting in the tectonic development of the midcontinent, U.S.A. Tectonophysics, 94(1-4), 391412. http://doi.org/10.1016/0040-1951(83)90026-4

Keller, R. (2017). The southern Oklahoma aulacogen, 254(January). http://doi.org/10.1016/S0419-0254(06)80020-0

Kelson, K., \& Swan, F. H. (1990). Palesoseismic History of the Meers Fault, Southwestern, Oklahoma, and implications for evaluations of Earthquake Hazards in the Central and Eastern United States.

Lienkaemper, J.J., and Ramsey, C.B., 2009, OxCal: Versatile Tool for Developing Paleoearthquake Chronologies--A Primer: Seismological Research Letters, v. 80, p. 431-434, doi: 10.1785/gssrl.80.3.431.

Luza, K. V, Madole, R. F., \& Crone, A. J. (1987). Investigation of the Meers Fault, Southwestern Oklahoma. Oklahoma Geological Survey Special Publication (Vol. 87-1). Oklahoma Geological Survey.

Madole, R. F. (1988). Geological Society of America Bulletin Stratigraphic evidence of Holocene faulting in the mid-continent : The Meers Fault, southwestern Oklahoma Stratigraphie evidence of Holocene faulting in the mid-continent : The Meers Fault, southwestern Oklahoma. http://doi.org/10.1130/0016-7606(1988)100<0392 
McNamara, D. E., Benz, H. M., Herrmann, R. B., Bergman, E. A., Earle, P., Holland, A., ... Gassner, A. (2015). Earthquake hypocenters and focal mechanisms in central Oklahoma reveal a complex system of reactivated subsurface strike-slip faulting. Geophysical Research Letters, 42(8), 2742-2749. http://doi.org/10.1002/2014GL062730

Micheletti, N., Chandler, J. H., \& Lane, S. N. (2015). Structure from Motion ( SfM ) Photogrammetry Photogrammetric heritage, 2, 1-12.

Moody, J.D, Hill, M. . (1956). Wrench-Fault Tectonics. Bulletin of the Geological Society of America, 67(September), 1207-1246.

Perry, W. J. (1989). Tectonic Evolution of the Anadarko Basin Region, Oklahoma. In Evolution of Sedimentary Basins (pp. A1-A19). Denver, CO: United States Geological Survey.

Ramelli, A. R., \& Slemmons, D. . (1990). Implications of the Meers Fault on Seismic Potential in the Central United States. Geological Society of America Reviews in Engineering Geology, 8, 59-75.

Reimer, P.J, Bard, E., Bayliss, A., Beck, J. W. (2016). IntCal13 and Marine13 Radiocarbon Age Calibration Curves 0-50,000 Years Cal BP. Radiocarbon, 55(4), 1869-1887.

Reitman, N. G., Bennett, S. E., Gold, R. D., Briggs, R. W., \& DuRoss, C. B. (2015). High- resolution trench photomosaics from image- based modeling: Workflow and error analysis. Bulletin of the Seismological Society of America. Vol. 105, No. 5, doi: 10.1785/0120150041

Rittenour, T. M. (2008). palaeoseismic and archaeological research, 2008. http://doi.org/10.1111/j.1502-3885.2008.00056.x

Stokes, S. (1999). Luminescence dating applications in geomorphological research, (October 1998).

U.S. Geological Survey, 2006, Quaternary fault and fold database for the United States, accessed October 2015, from USGS web site: http//earthquakes.usgs.gov/hazards/qfaults/.

Walsh, F. R., \& Zoback, M. D. (2016). Probabilistic assessment of potential fault slip related to injection- induced earthquakes : Application to north-central Oklahoma , USA, 44(12), 991-994. http://doi.org/10.1130/G38275.1

Wells, D. L., \& Coppersmith, K. J. (1994). New Empirical Relationships among Magnitude, Rupture Length, Rupture Width, Rupture Area, and Surface Displacement. Bulletin of the Seismological Society of America, 84(4), 974-1002. 
Wheeler, R. L., \& Crone, A. J. (2001). Known and suggested quaternary faulting in the midcontinent United States. Engineering Geology, 62(1-3), 51-78.

http://doi.org/10.1016/S0013-7952(01)00050-3

Zielke, O., Arrowsmith, J. R., Grant Ludwig, L., \& Akçiz, S. O. (2010). Slip in the 1857 and earlier large earthquakes along the Carrizo Plain, San Andreas Fault. Science (New York, N.Y.), 327, 1119-1122. http://doi.org/10.1126/science.1182781 


\section{Appendix A: Additional Balloon-Based SfM and Lidar Data}

Appendix A contains balloon-based SfM and airborne lidar data for the B3, B5, $B 6$, and B7 SfM balloon-based datasets. In each figure; $(A)$ is a hillshade image generated from a balloon-based SfM derived digital surface model (DSM), (B) is a hillshade image created from the lidar based DEM (which was clipped to the bounding extent of the SfM dataset), (C) is the cloud to cloud absolute distances, creating from subtracting the SfM based point clouds from lidar point clouds and is provided with mean distance values, (D) shows orthomosaics of the study areas, mosaiced using balloon-based SfM overlapping photographs. The B7 dataset was flown past the extent of lidar coverage. 

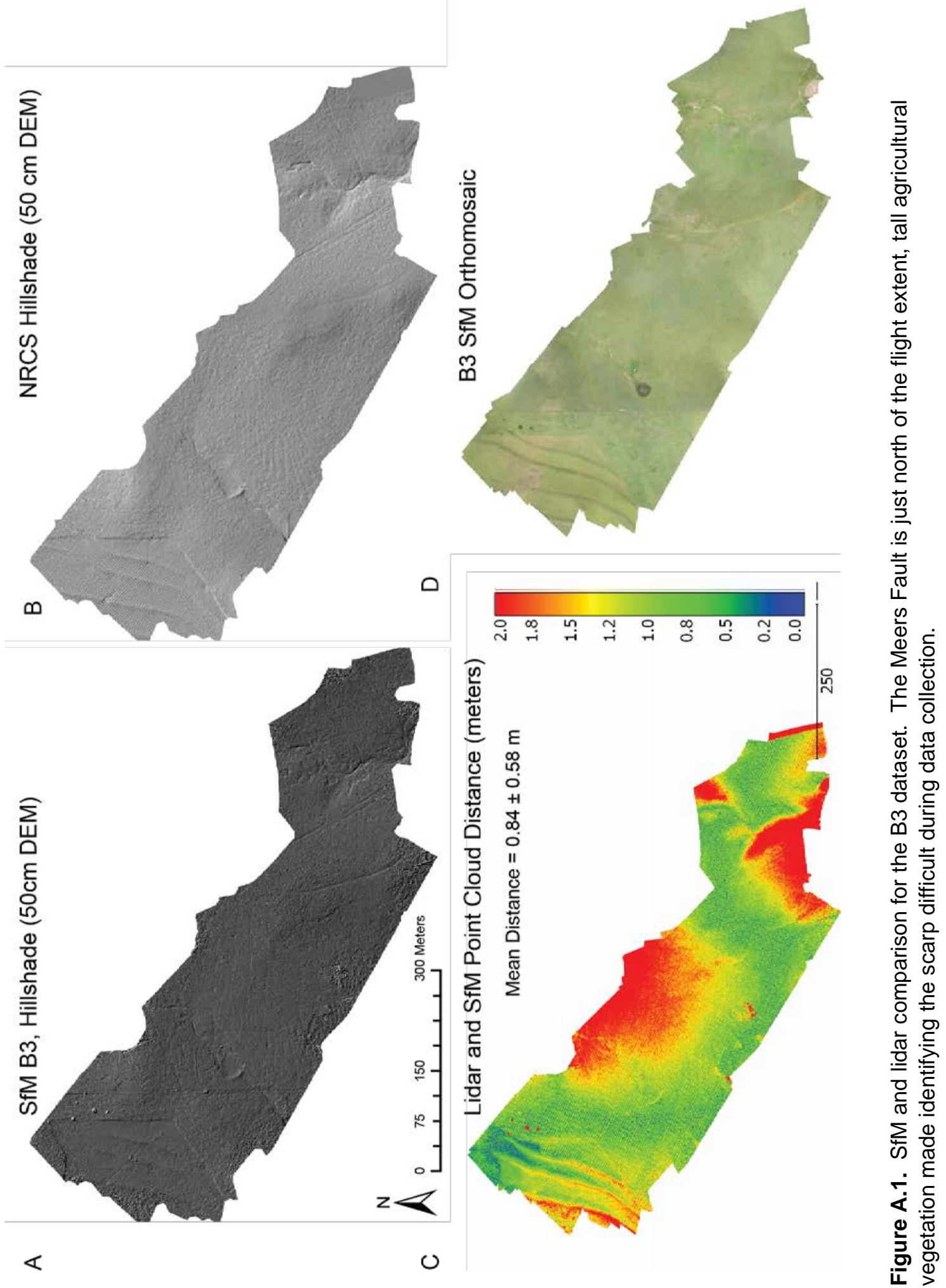


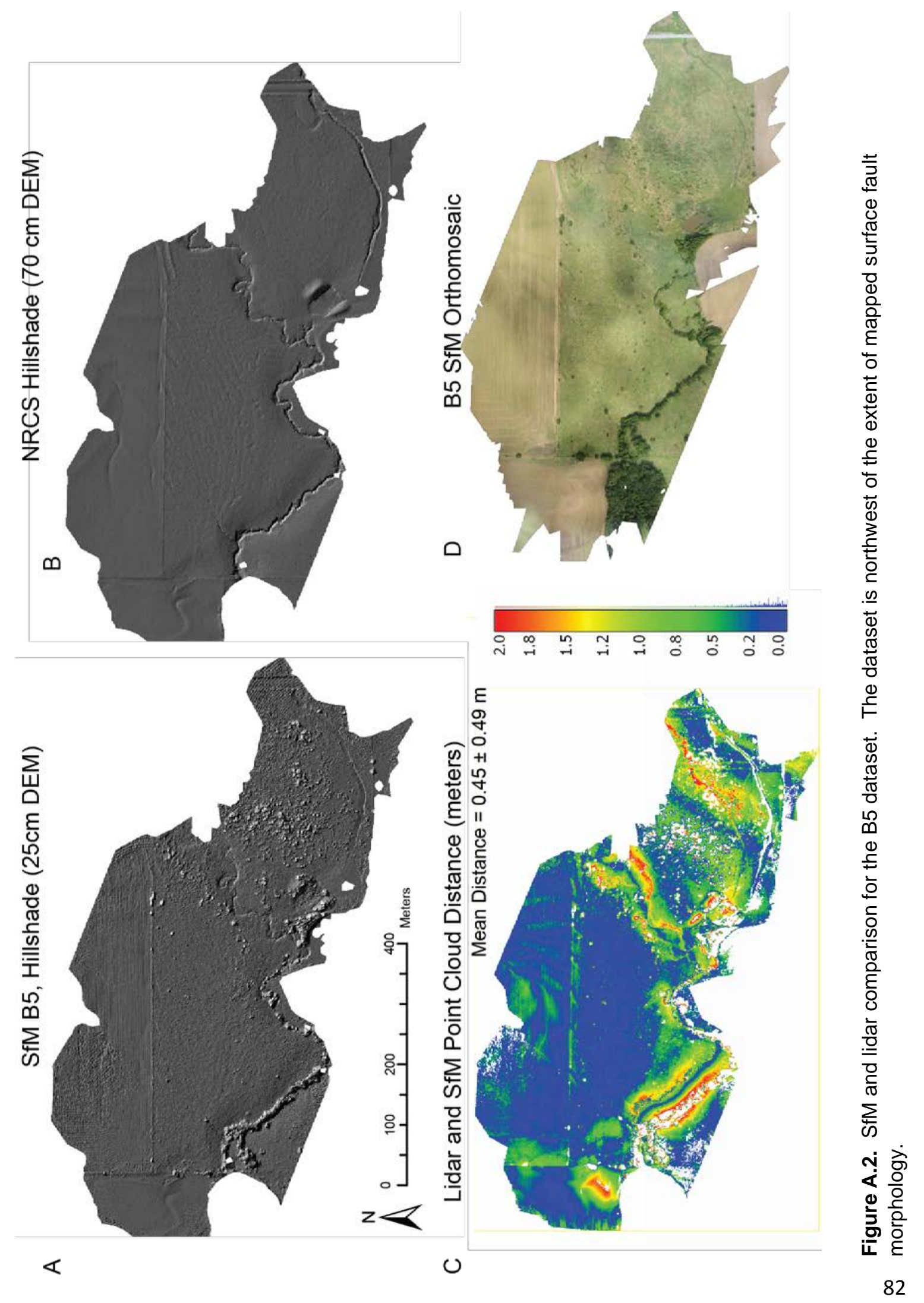




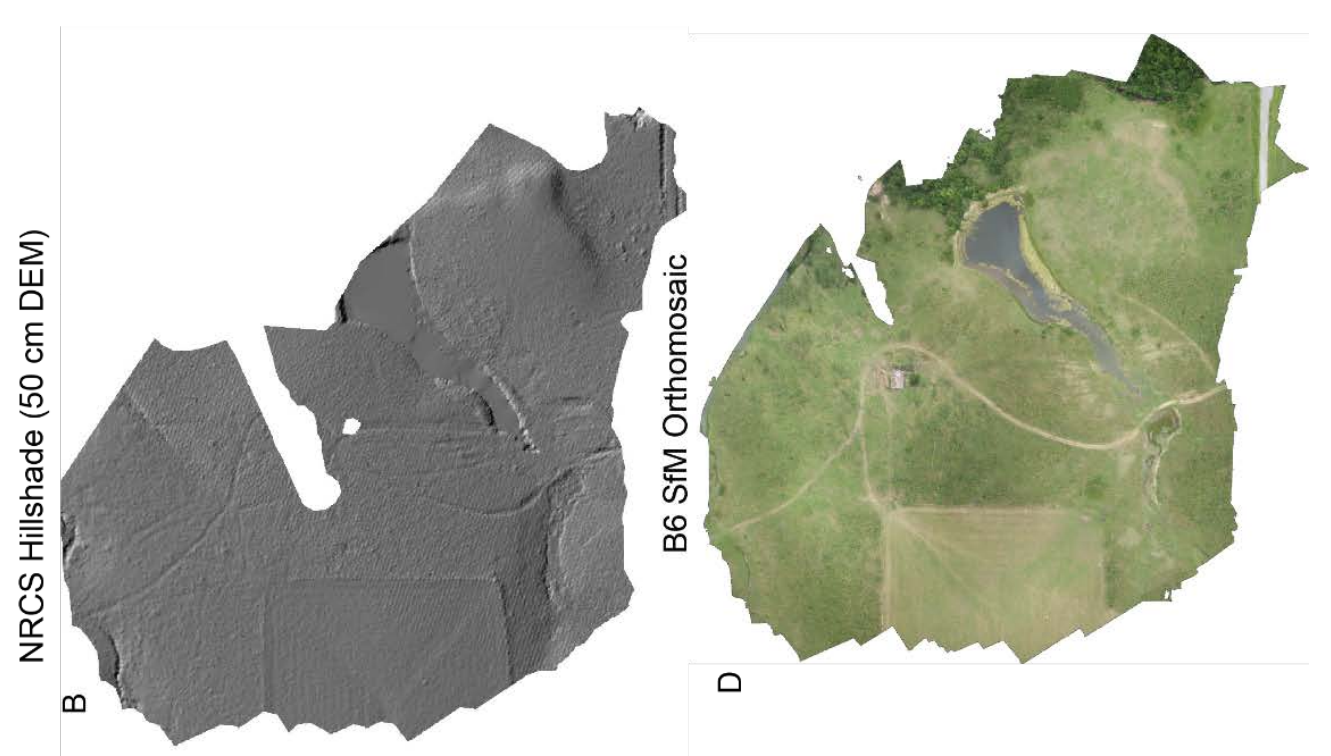

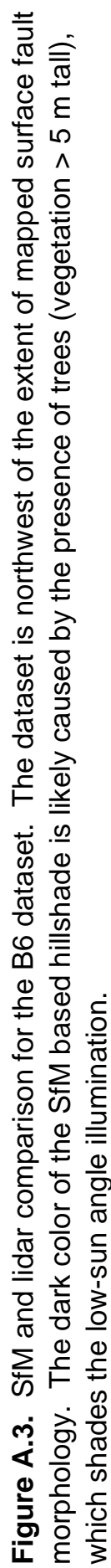

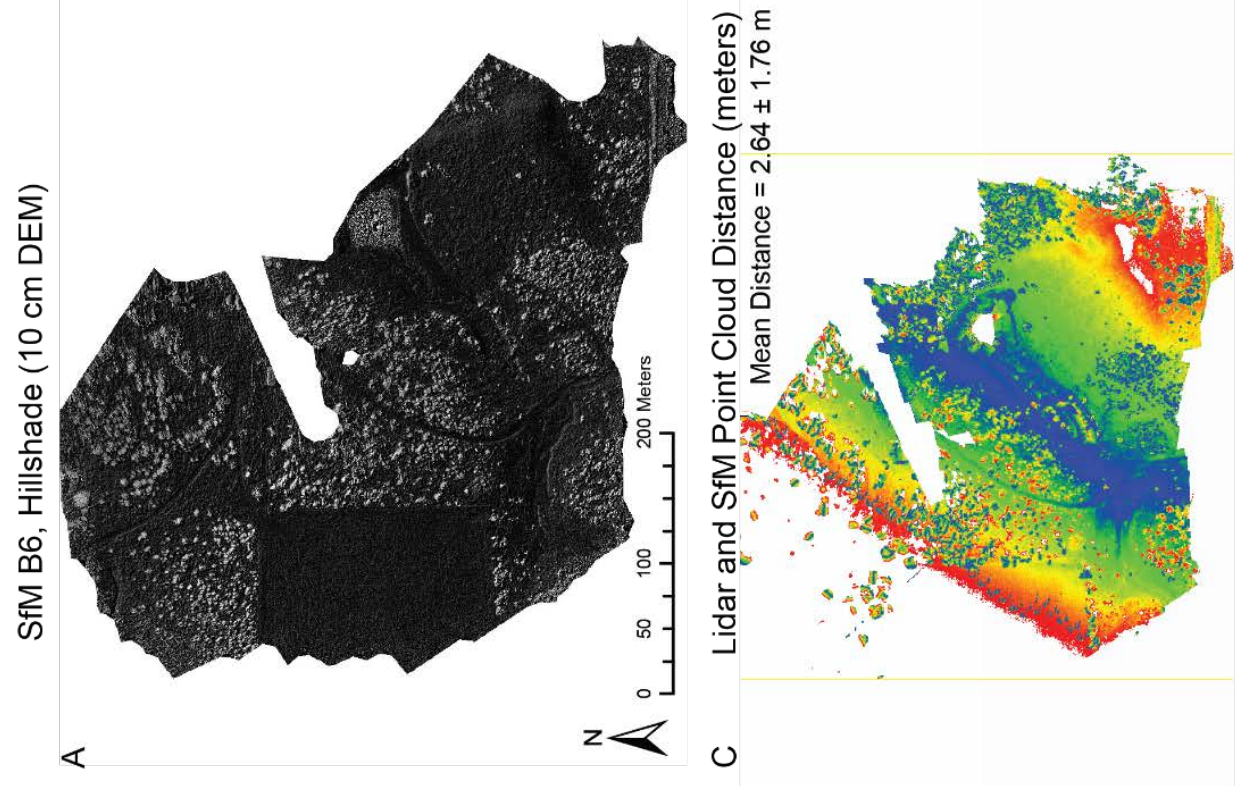




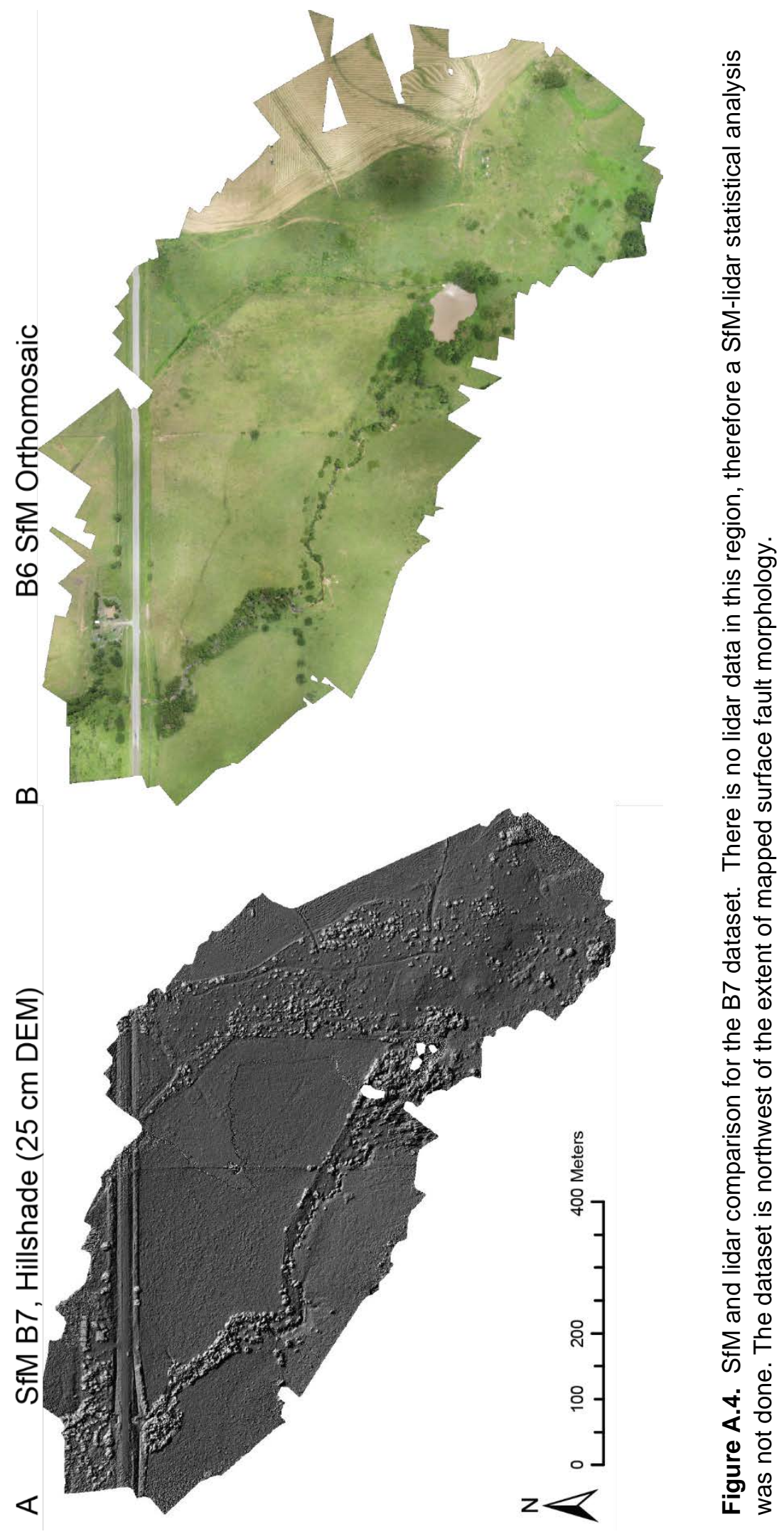




\section{Appendix B: Additional Topographic Profiles}

Appendix B contains additional topographic profiles that were measured and used for the analysis of vertical separation and deformation style across the Meers Fault. 

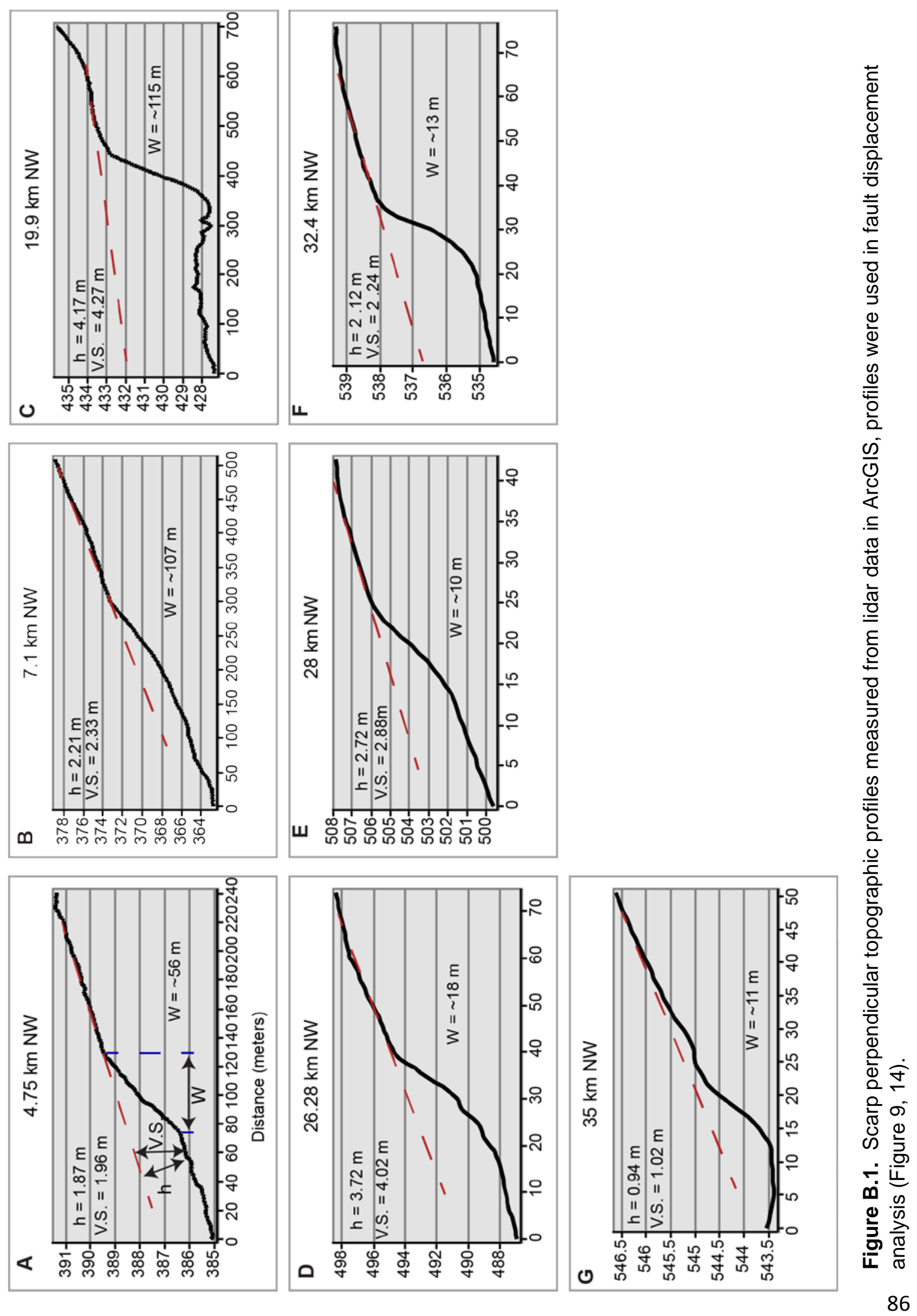


\section{Appendix C: Paleoseismic Trench Detailed Unit Descriptions}

\begin{tabular}{|c|c|c|}
\hline $\begin{array}{c}\text { Unit } \\
\text { Sequence }\end{array}$ & Unit Description & $\begin{array}{l}\text { Depositional } \\
\text { Environment }\end{array}$ \\
\hline $1 a$ & $\begin{array}{l}\text { Silt with sparse gravel up to } 1 \mathrm{~cm}(<2 \%) \text {; (dark reddish grey, } 2.5 \text { YR } 3 / 1 \text { ); } \\
\text { damp; very loose; well sorted and massive; abundant hairline rootlets } \\
\text { with some roots up to } 2 \mathrm{~mm} \text {; A horizon soil development; clear basal } \\
\text { contact. }\end{array}$ & $\begin{array}{l}\text { overbank } \\
\text { alluvium }\end{array}$ \\
\hline $1 b$ & $\begin{array}{l}\text { Silt; very (dark grey, } 7.5 \text { YR 3/1); damp; loose; well sorted and massive; } \\
\text { sparse modern rootlets; weakly developed irregular pedogenic } \\
\text { structures; locallized } \mathrm{CaCO} 3 \text { nodules up to } 4 \mathrm{~mm} \text {, B horizon soil } \\
\text { developlment; gradational basal contact. }\end{array}$ & $\begin{array}{l}\text { overbank } \\
\text { alluvium }\end{array}$ \\
\hline $1 c$ & $\begin{array}{l}\text { Sandy-silt (<5\% sand); (brown, } 7.5 \text { YR } 4 / 4) \text {; damp, medium dense; well- } \\
\text { sorted; massive; sparse sub-angular gravel }(<1 \%) \text {; strong prismatic } \\
\text { pedogenic structure with well developed translocated clay films; sparse } \\
<1 \mathrm{~mm} \text { rootlets; abundant boxwork } \mathrm{CaCO} 3 \text { veinlets up to } 1 \mathrm{~mm} \text { and cream } \\
\text { colored sub-rounded } \mathrm{CaCO} 3 \text { nodules up to } 1 \mathrm{~mm} \text {; clear basal contact. }\end{array}$ & $\begin{array}{l}\text { overbank } \\
\text { alluvium }\end{array}$ \\
\hline $2 a$ & $\begin{array}{l}\text { Medium- coarse gravel with a silty sand matrix; (dark yellowish-brown, } 10 \\
\text { YR 3/6); damp; loose; poorly sorted; } 80 \% \text { of clasts }>2 \mathrm{~mm} \text { and } 40 \%>5 \mathrm{~mm} \\
\text { (sub-angular to sub-rounded gravels up to } 4 \mathrm{~cm} \text { ); clast size and abundance } \\
\text { decrease to the south; sharp basal contact. }\end{array}$ & $\begin{array}{l}\text { stream } \\
\text { channel } \\
\text { deposits }\end{array}$ \\
\hline $2 b$ & $\begin{array}{l}\text { Sandy-silt; (brown, } 10 \text { YR 4/3); damp; loose poorly sorted; massive; } \\
\text { increased silt matrix from } 2 \text { a with } 20 \% \text { clasts }>2 \mathrm{~mm} \text { and } 10 \% \text { sub-angular } \\
\text { gravel }>5 \mathrm{~mm} \text { (up to } 5 \mathrm{~cm} \text { ); weak irregular pedogenic structure; sparse } \\
\text { modern rootlets }(<1 \mathrm{~mm} \text { ); localized bioturbation ; sub-rounded } \mathrm{CaCO} 3 \\
\text { nodules up to } 1 \mathrm{~cm} \text { are present; gradational basal contact over } 10 \mathrm{~cm} \text {. }\end{array}$ & $\begin{array}{l}\text { overbank } \\
\text { alluvium }\end{array}$ \\
\hline $2 c$ & $\begin{array}{l}\text { Silt; (dark greyish- brown to brown, } 10 \text { YR } 4 / 2 \text { to } 4 / 3 \text { ); damp; loose; gravels } \\
\text { make up } 10 \% \text { of unit and are predominately }<1 \mathrm{~cm} \text {; similar to } 2 \mathrm{~b} \text { with } \\
\text { increased silt content, slightly more well developed irregular pedogenic } \\
\text { structure; diffuse basal contact. }\end{array}$ & $\begin{array}{l}\text { overbank } \\
\text { alluvium }\end{array}$ \\
\hline $2 d$ & $\begin{array}{l}\text { Sandy loam; (reddish-brown, } 7.5 \text { YR 5/4); damp; dense; abundant coarse } \\
\text { sand and fine-grained clasts, } 15-20 \% \text { of grains are }>1 \mathrm{~mm} \text {; sub-rounded } \\
\text { clast supported layers up to } 2 \mathrm{cminterbedded} \text { with dark silt layers up to } 2 \\
\mathrm{~cm} \text { with soil overprint; moderately to well sorted; breaks into strong, } \\
\text { well-developed rectangular pedogenic blocks up to } 10 \mathrm{~cm} \text {; thin CaCO3 } \\
\text { fracture coating; very sparse thin rootlets; abundant oxide nodules up to } \\
1 \mathrm{~mm} \text {; gradational basal contact over } 20 \mathrm{~cm} \text {. }\end{array}$ & $\begin{array}{l}\text { overbank } \\
\text { flood deposits } \\
\text { and silt }\end{array}$ \\
\hline
\end{tabular}




\begin{tabular}{|c|c|c|}
\hline $\begin{array}{c}\text { Unit } \\
\text { Sequence }\end{array}$ & Unit Description & $\begin{array}{l}\text { Depositional } \\
\text { Environment }\end{array}$ \\
\hline $2 e$ & $\begin{array}{l}\text { Silt; dark brown; damp; loose; }<5 \% \text { clasts up to } 2 \mathrm{~cm} \text {; buried soil } \\
\text { development; sharp basal contact. }\end{array}$ & alluvium \\
\hline $2 f$ & $\begin{array}{l}\text { Silt; (brown, } 7.5 \text { YR 4/3); interbedded with silty-sand; reddish-yellow ( } 7.5 \\
\text { YR 6/6); damp; medium dense; silt layers contain sparse fine grained } \\
\text { clasts up to } 3 \mathrm{~mm} \text {; weak rectangular pedogenic structure with clay frature } \\
\text { coating; Silty-sand deposits contain } \sim 20 \% \text { clasts that are } 2-4 \mathrm{~mm} \text {; clear } \\
\text { basal contact over } 5 \mathrm{~cm} \text {. }\end{array}$ & $\begin{array}{l}\text { overbank } \\
\text { flood } \\
\text { alluvium }\end{array}$ \\
\hline $2 g$ & $\begin{array}{l}\text { Medium gravel; dark brown silt-rich matrix ( } 7.5 \text { YR } 3 / 3 \text { ); damp; loose; clast } \\
\text { supported unit with } 15 \% \text { silt loam, } 85 \% \text { of material is }>2 \mathrm{~mm} \text {, sub-rounded } \\
\text { gravels up to } 5 \mathrm{~cm} \text {, typically }<2 \mathrm{~cm} \text {; moderately to poorly sorted; massive; } \\
\text { sharp basal contact. }\end{array}$ & $\begin{array}{l}\text { high-energy } \\
\text { fluvial }\end{array}$ \\
\hline $2 \mathrm{~h}$ & $\begin{array}{l}\text { Loam (clayey-silt); grey/brown to orange/tan mottled color; damp; } \\
\text { medium dense; abundant (10-15\%) fine grained clasts typically } 1-3 \mathrm{~mm} \text {; } \\
\text { sparse modern rootlets; gradational basal contact over } 10 \mathrm{~cm} \text {. }\end{array}$ & $\begin{array}{c}\text { scarp derived } \\
\text { colluvium }\end{array}$ \\
\hline $3 a-3 g$ & $\begin{array}{l}\text { Fine-medium gravel interbedded with clayey-silt units; damp; loose to } \\
\text { medium dense; clayey-silt units have }<10 \% \text { fine grained gravel clasts and } \\
\left.\text { thin deformed dark brown silt layers; beds are inclined ( } 20-40^{\circ}\right) \text {. 3a is a } \\
\text { thin, folded gravel bed. } 3 \text { b is a silty-clay; (brown to dark yellowish-brown, } \\
\text { (10 YR 4/3 to 4/4); <10\% clasts up to } 4 \mathrm{~mm} \text {. } 3 \mathrm{c} \text { is a silty-clay; (dark grayish } \\
\text { brown, } 10 \text { YR 4/2); very sparse clasts. } 3 \mathrm{~d} \text { is a medium gravel; (brown, } 7.5 \\
\text { YR 4/3); clast-supported; poorly sorted; sub-rounded gravel (up to } 4 \mathrm{~cm} \text { ) } \\
\text { with a silt-loam matrix; sharp basal contact. }\end{array}$ & $\begin{array}{l}\text { low-energy } \\
\text { ponded } \\
\text { alluvium } \\
\text { interbedded } \\
\text { with high- } \\
\text { energy fluvial } \\
\text { deposits }\end{array}$ \\
\hline 4 & $\begin{array}{l}\text { Silt; dark grayish-brown ( } 10 \text { YR 4/2); damp; dense; sparse }(<2 \%) \text { clasts }>2 \\
\mathrm{~mm} \text { and up to } 4 \mathrm{~cm} \text {; well-sorted; massive; abundant weathered (crumbly) } \\
\text { CaCO3 nodules up to } 1.5 \mathrm{~cm} \text {; sparse modern rootlets ( }<1 \mathrm{~mm} \text { ); well } \\
\text { developed irregular to blocky pedogenic structure with translocated clay } \\
\text { fracture coating; iron oxide nodules up to } 2 \mathrm{~mm} \text { throughout unit; clear } \\
\text { basal contact. }\end{array}$ & $\begin{array}{l}\text { overbank } \\
\text { alluvium }\end{array}$ \\
\hline 5 & $\begin{array}{l}\text { Shale; silty-clay; white to grey in color with mottled orange and yellow } \\
\text { iron oxidization patches; damp; dense; highly weathered, soft plastic } \\
\text { unit; bedding has been obliteration by weathering; Permian Hennessey } \\
\text { Shale. }\end{array}$ & $\begin{array}{c}\text { Permian basin } \\
\text { fill }\end{array}$ \\
\hline
\end{tabular}




\section{Appendix D: Additional Trench and Irrigation Ditch Photomosaics}

Appendix D contains photomosaics for the dogleg bend in the Water Mocassin trench as well as the adjacent faulted irrigation ditch exposure.
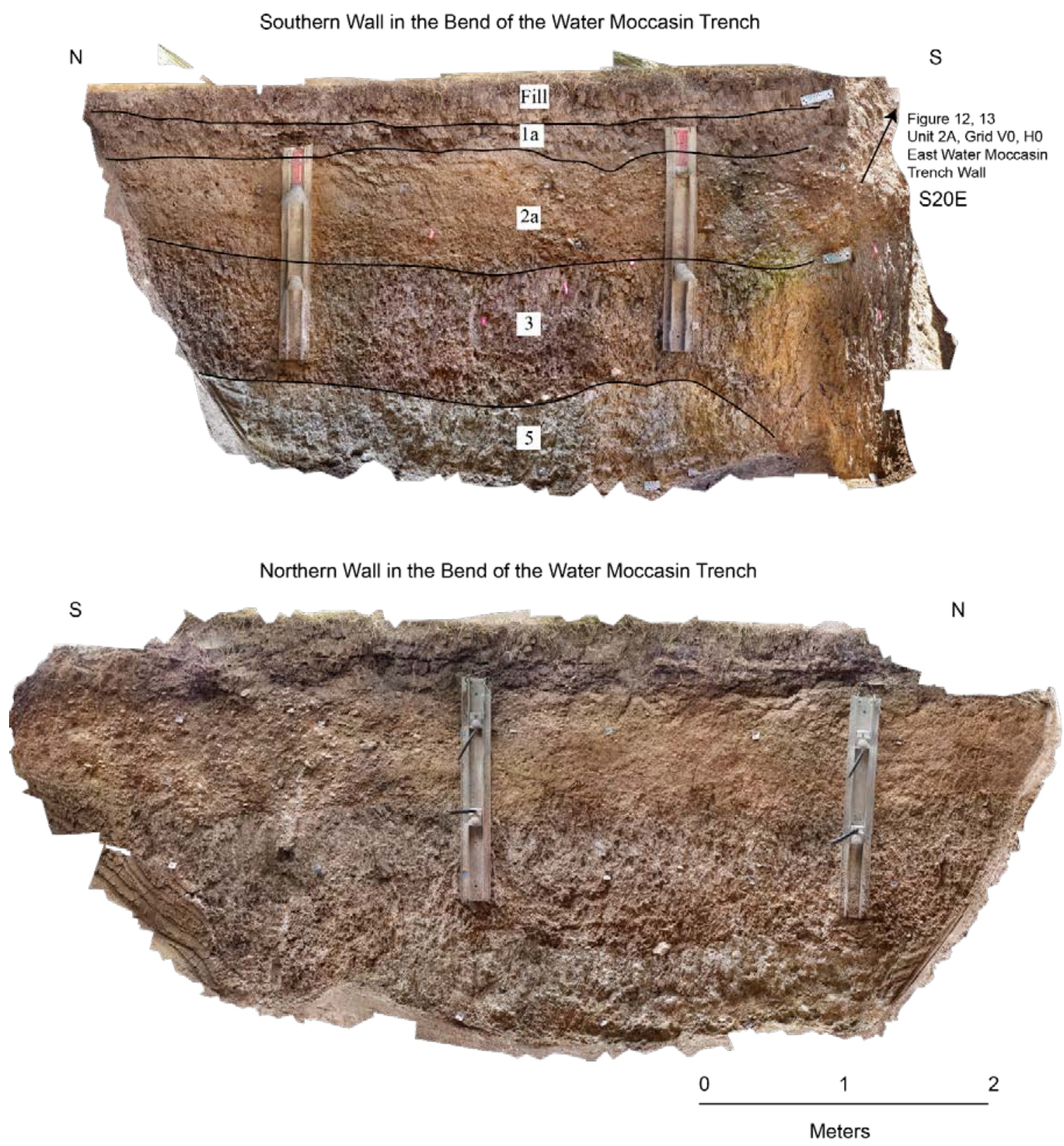

Figure D.1. Above) Photomosaic of the southern wall of the dogleg bend in the Water Moccasin trench with mapped units that correspond to units listed in Appendix C. Towards the southern edge the northern edge of the trench east wall beings. Below) Photomosaic of the northern wall of the dogleg bend. 


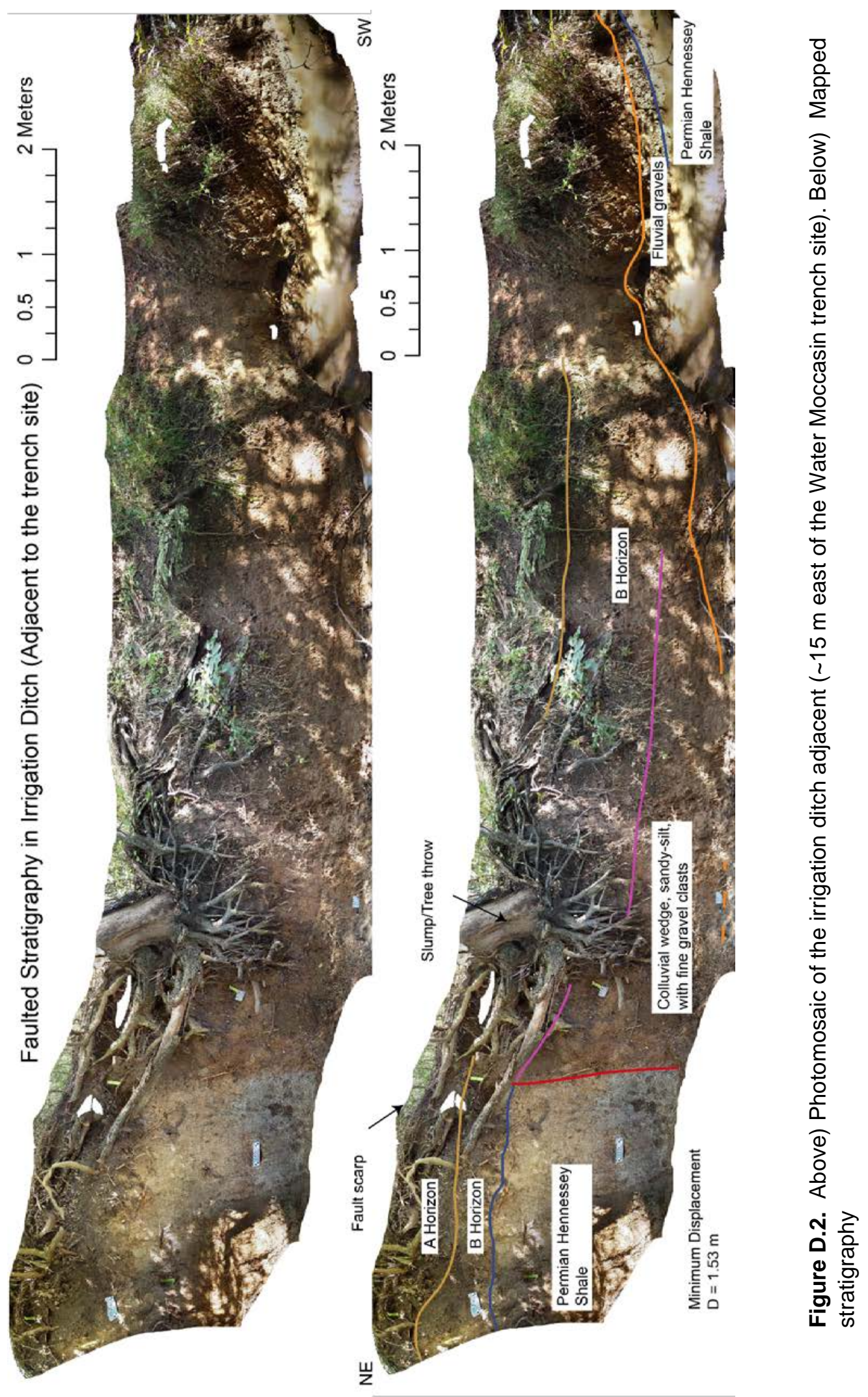




\section{Appendix E: Geophone Seismic Data}

Appendix E contains seismic profiles from the geophone survey collected across the trench site, shot 1 is the north end of the seismic line shown by the yellow line in (Figure 9) and shot 21 is the south end of the line. Very closely spaced geophone sensors (20 cm apart), double hammer strikes, and noise from wind and cattle make the data difficult to analyze and at the time are not considered in this analysis. 


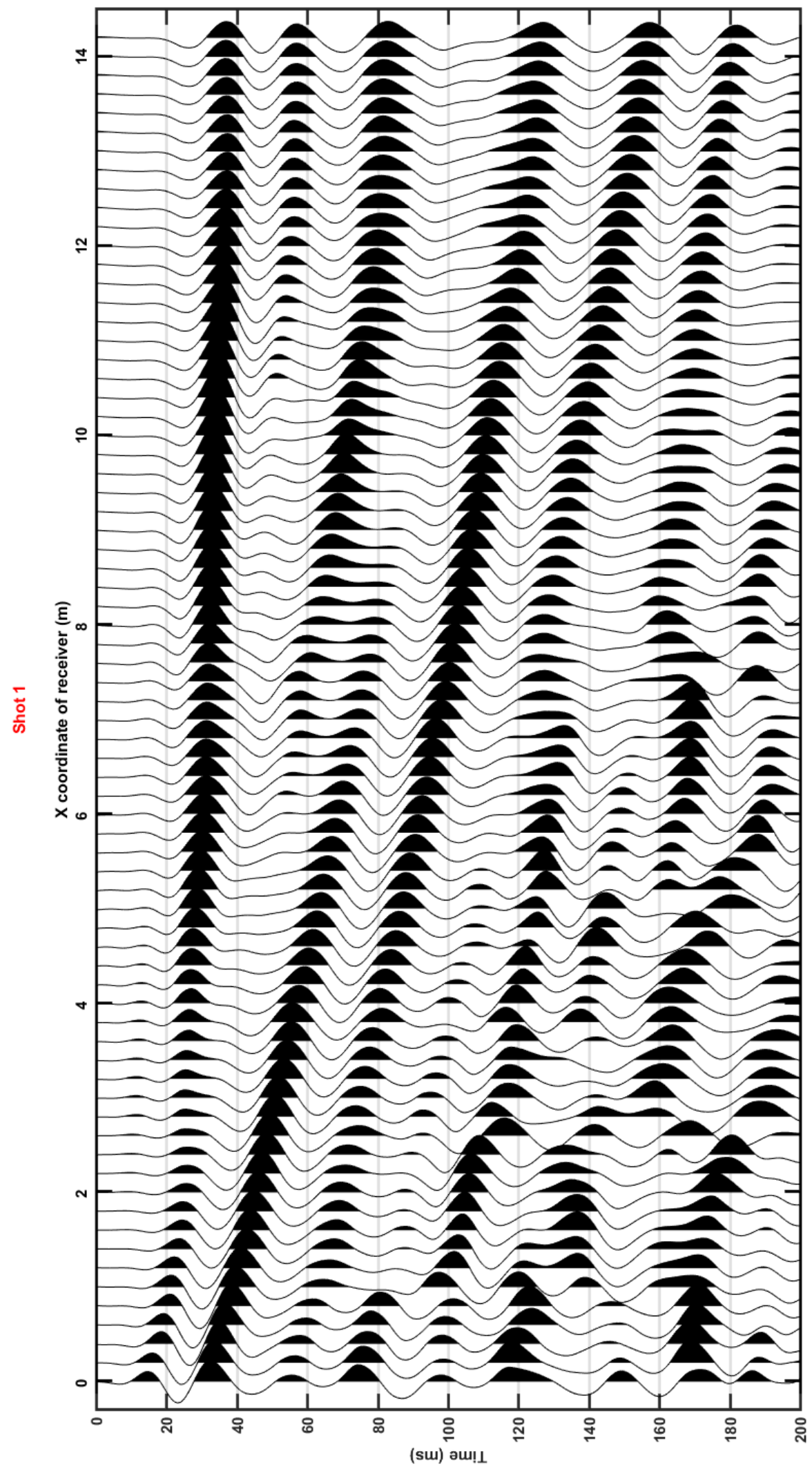




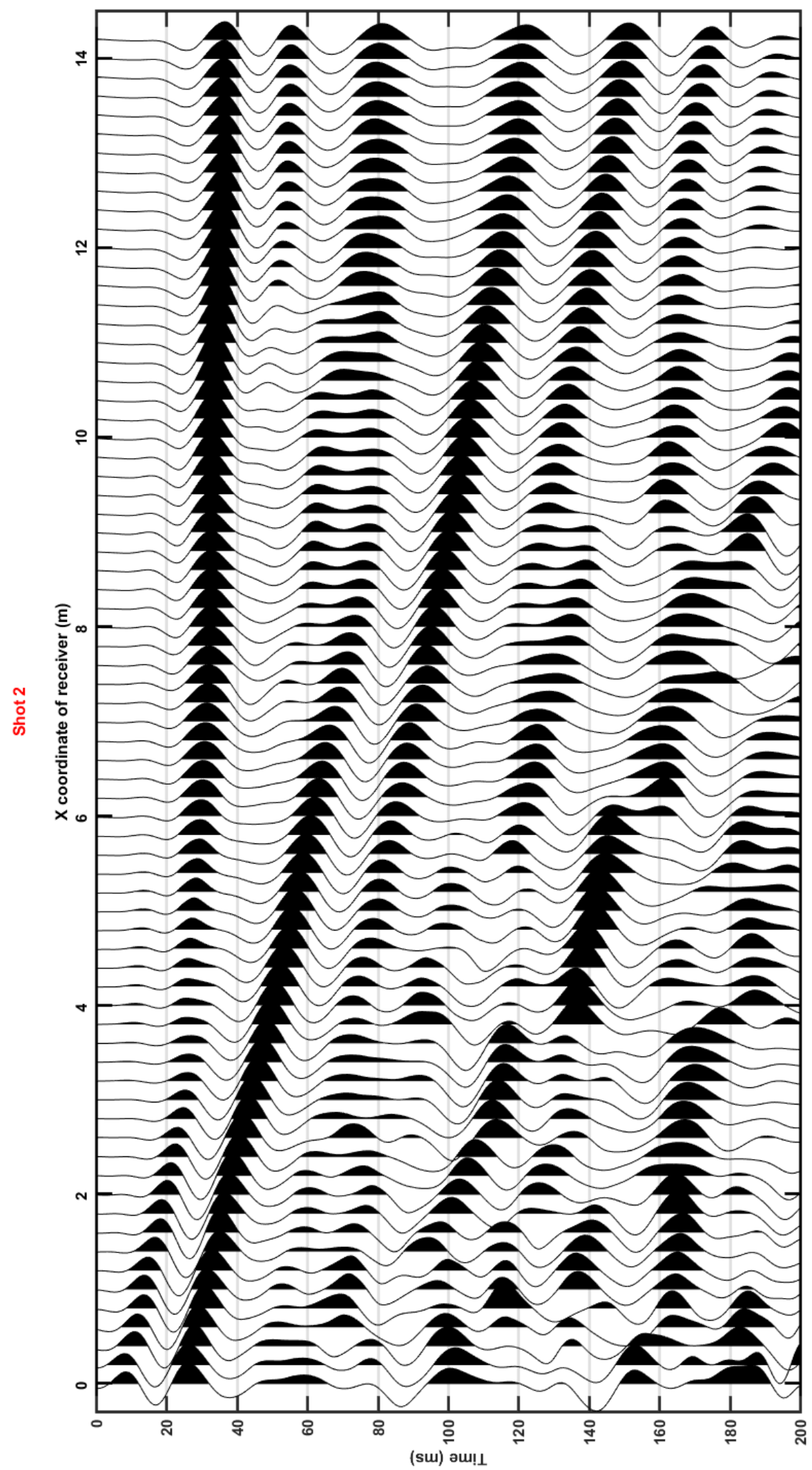




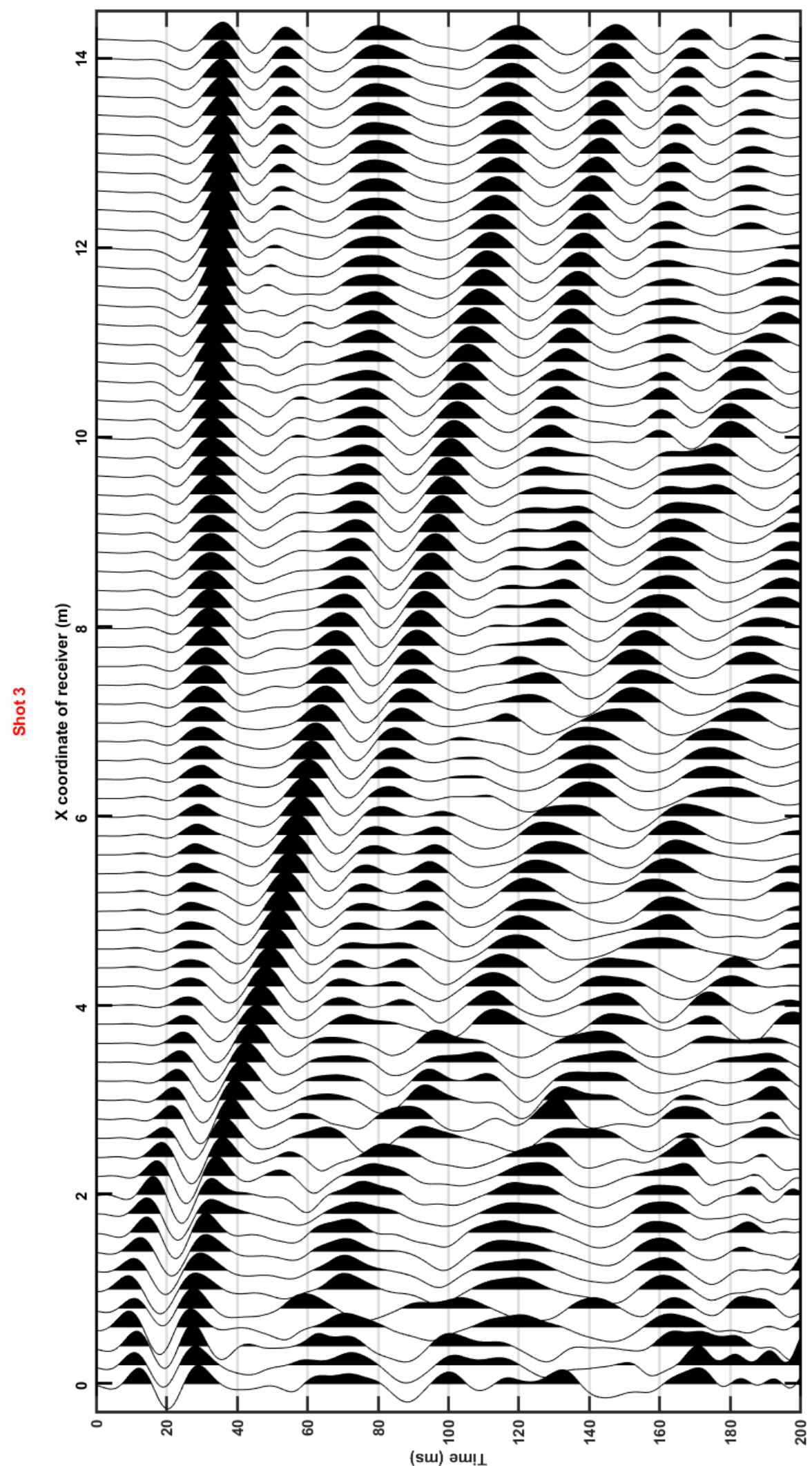




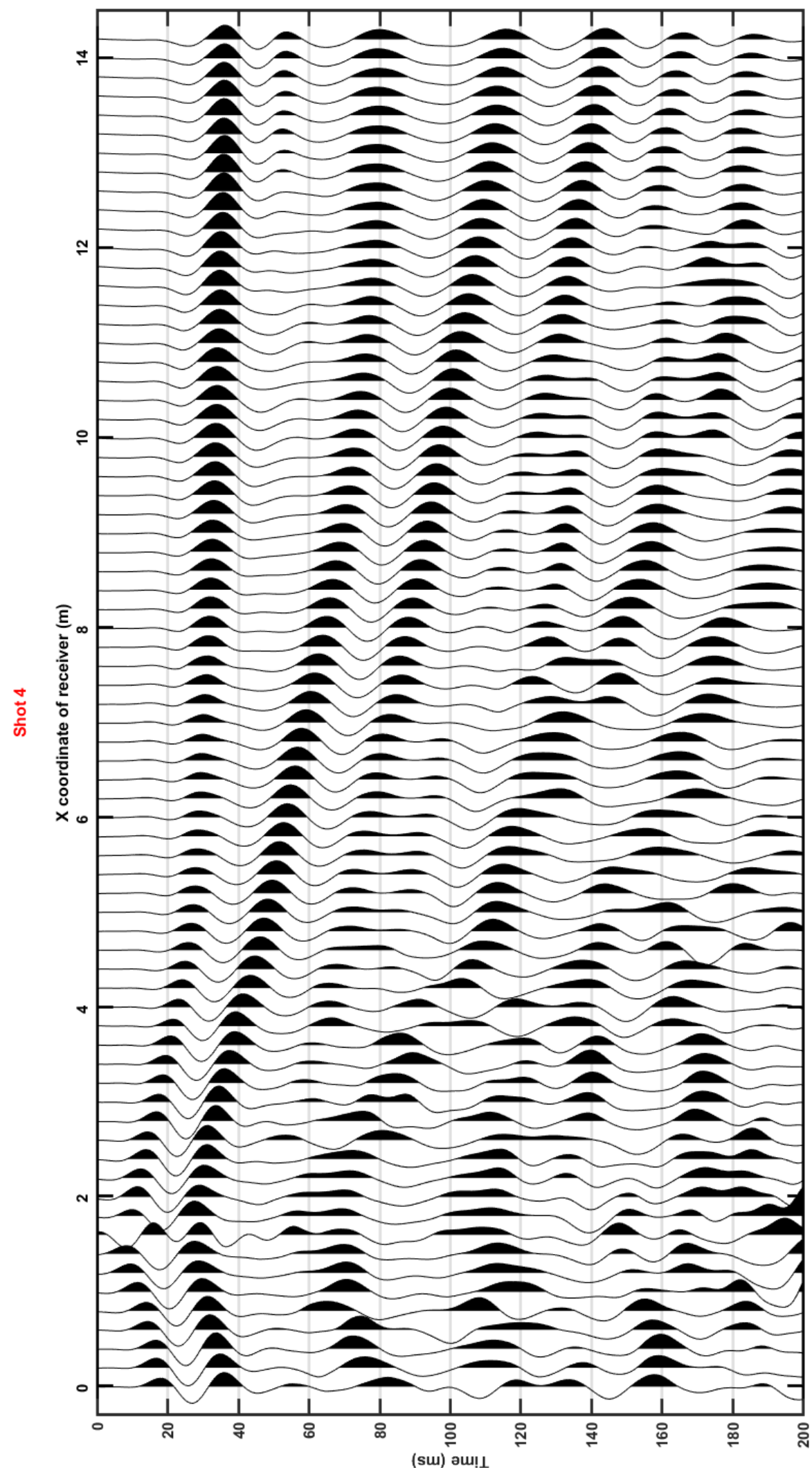

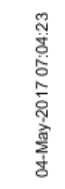




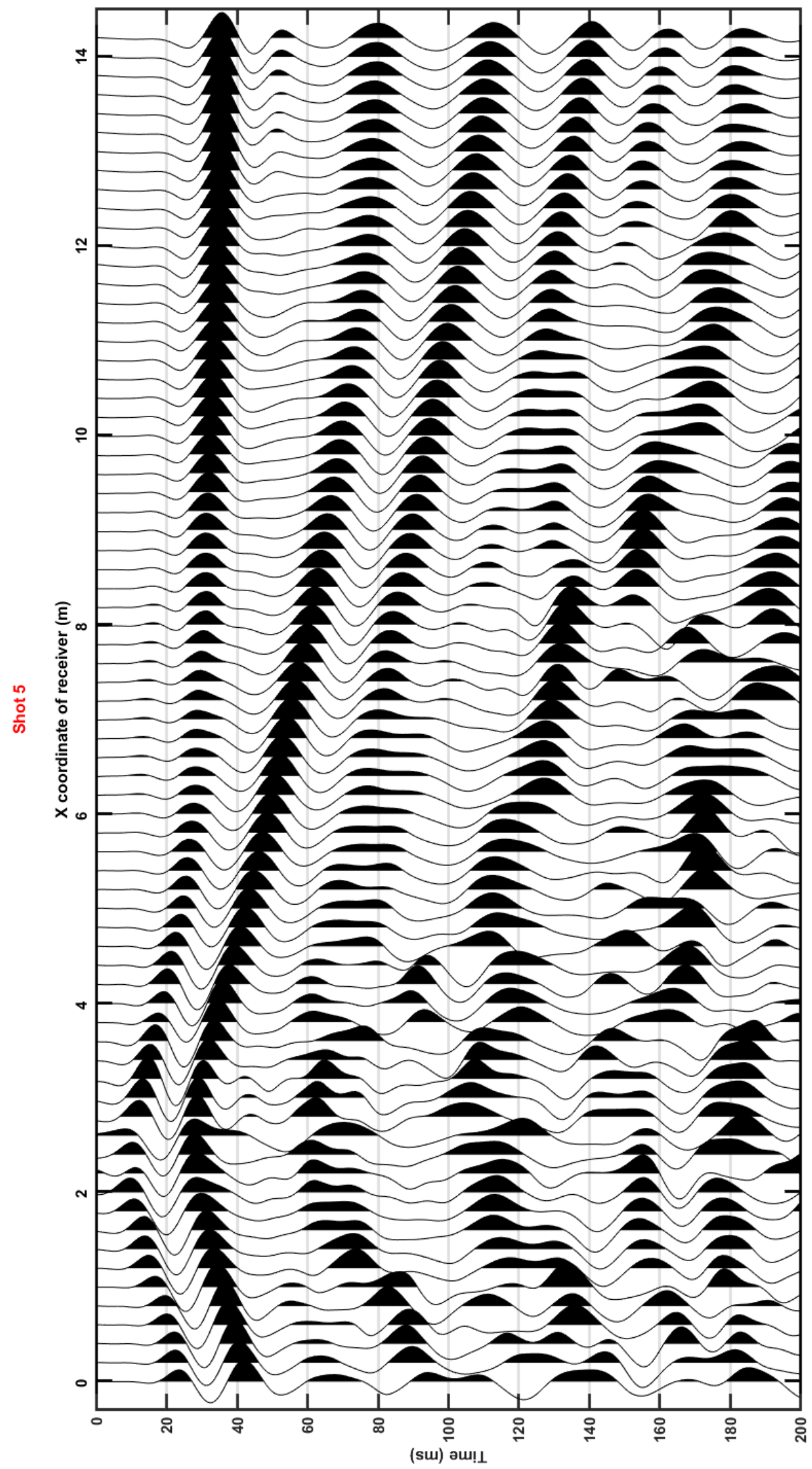




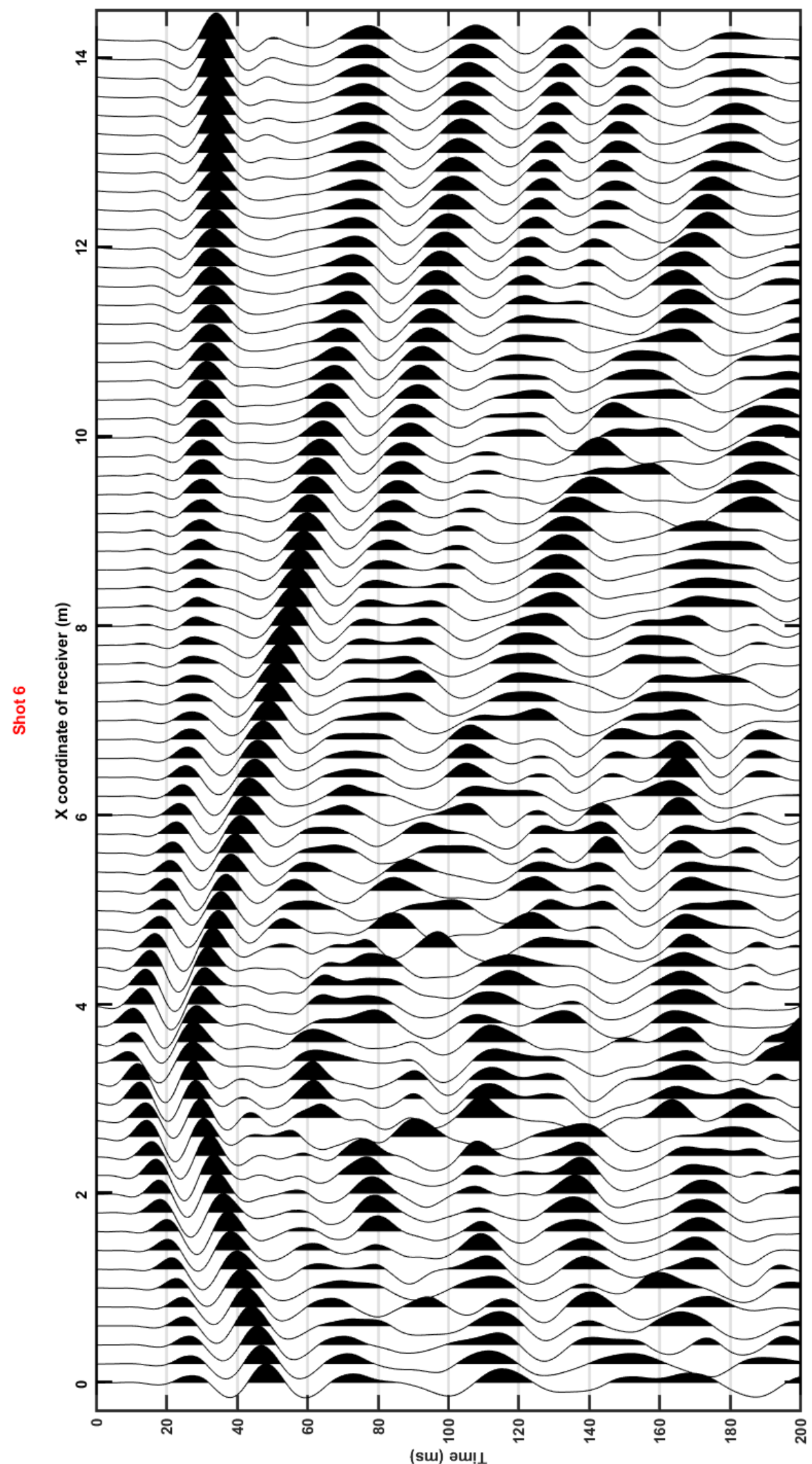




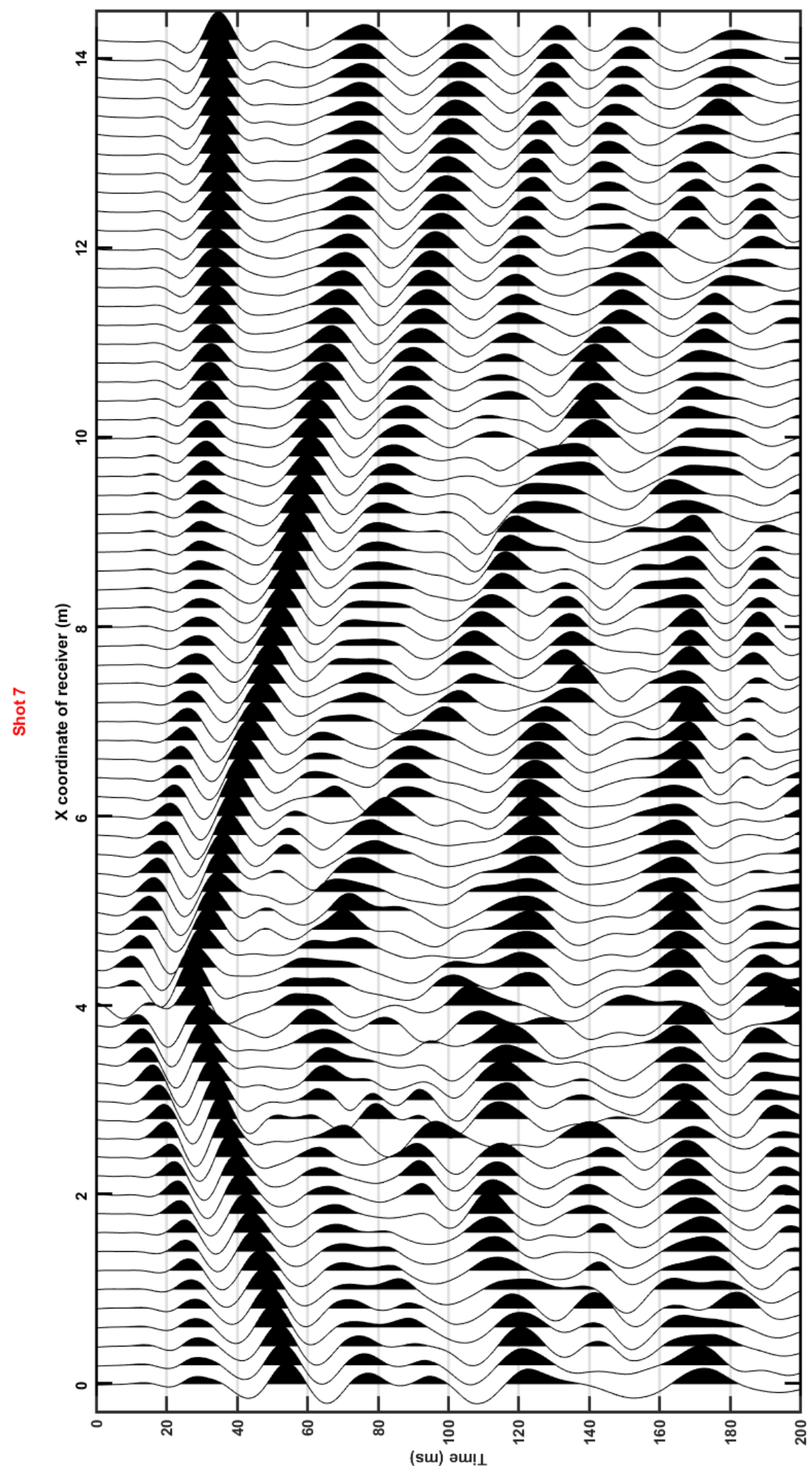




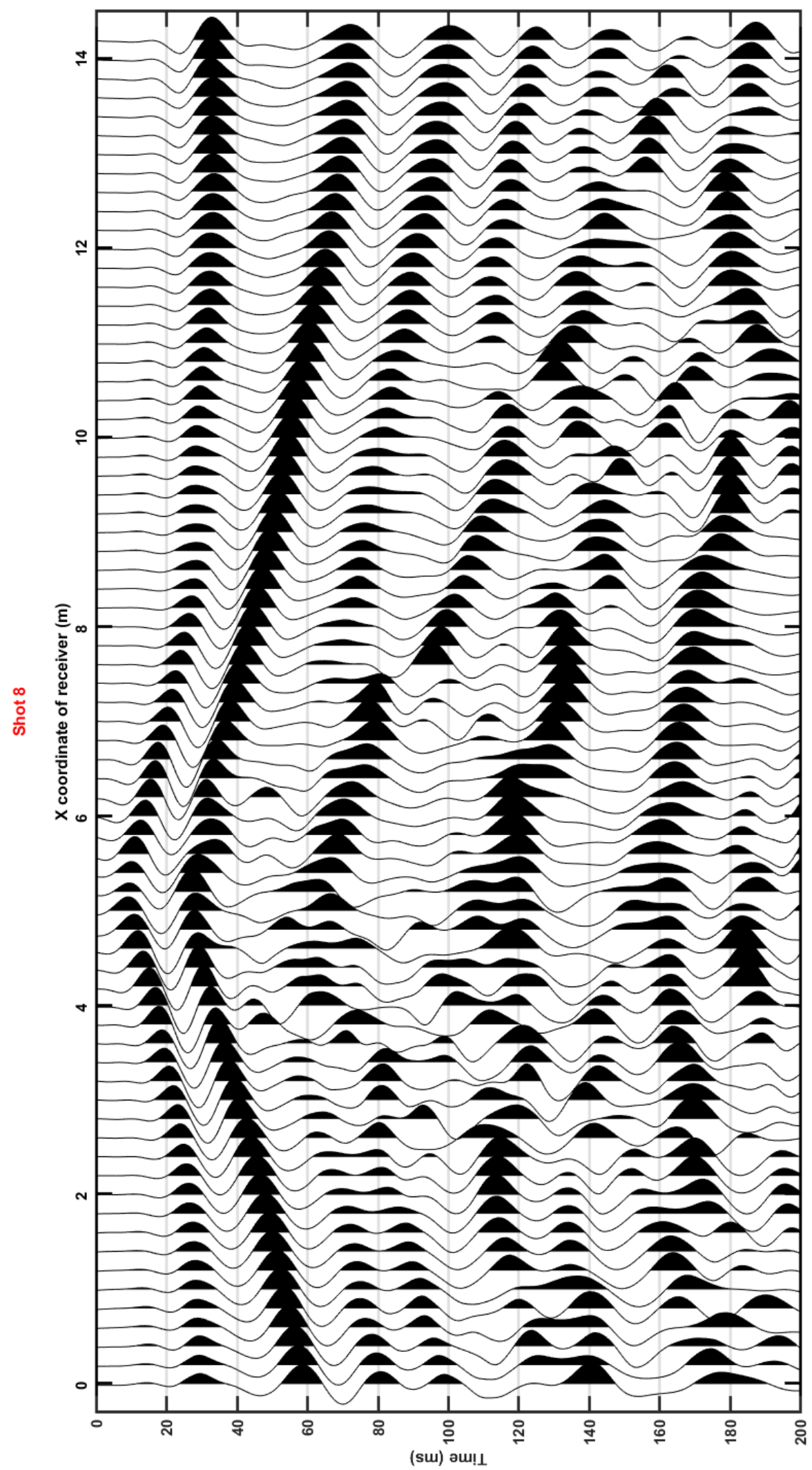




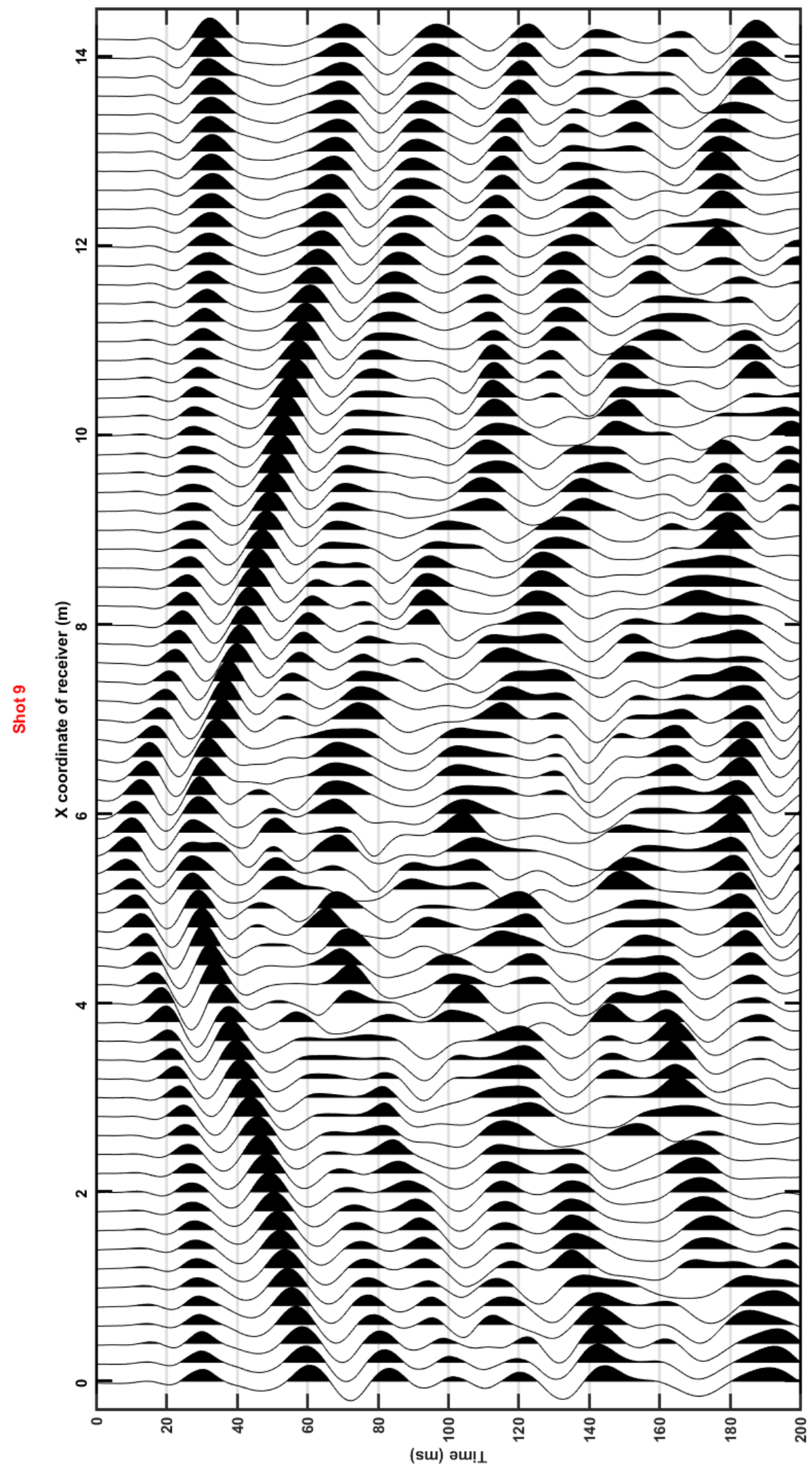




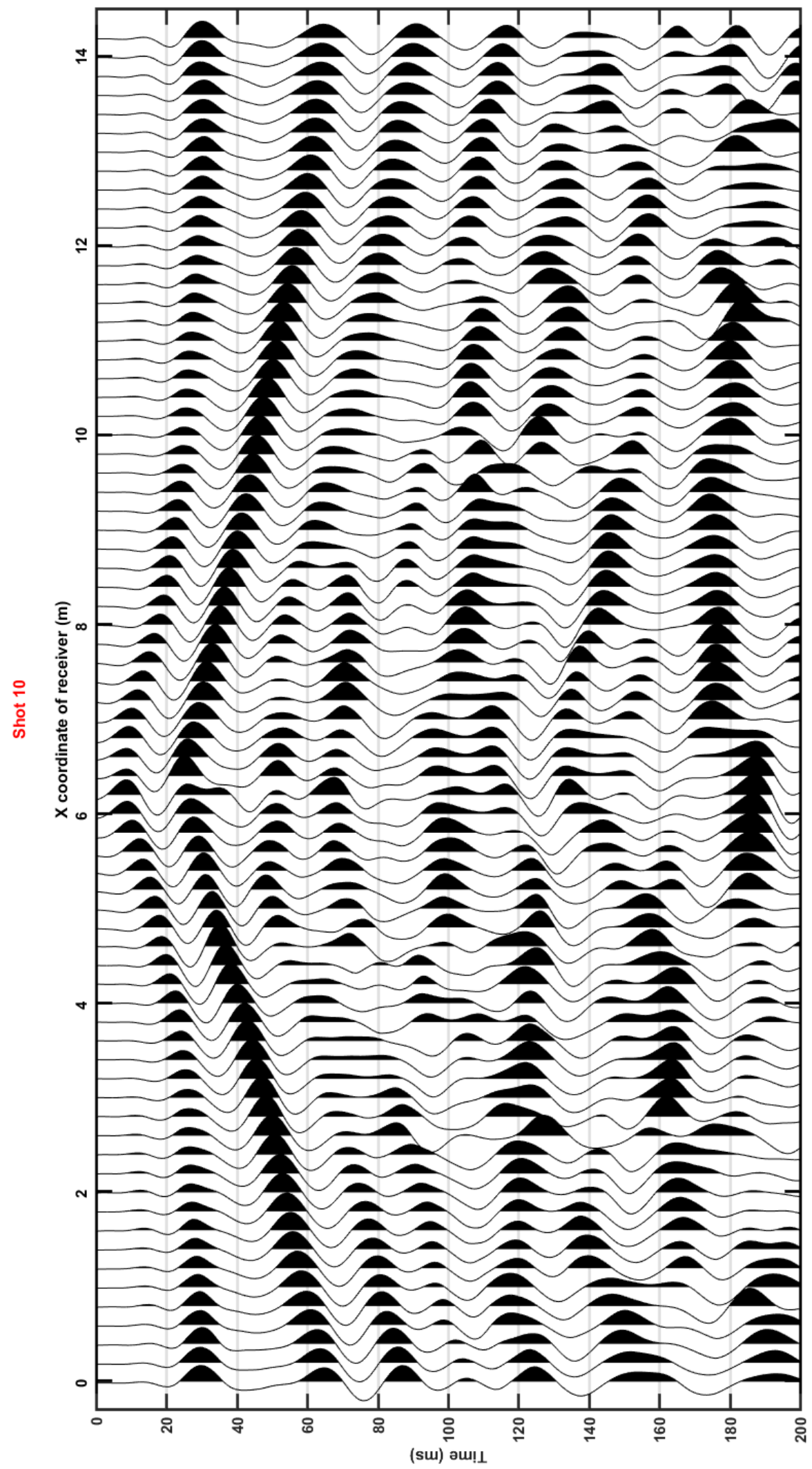




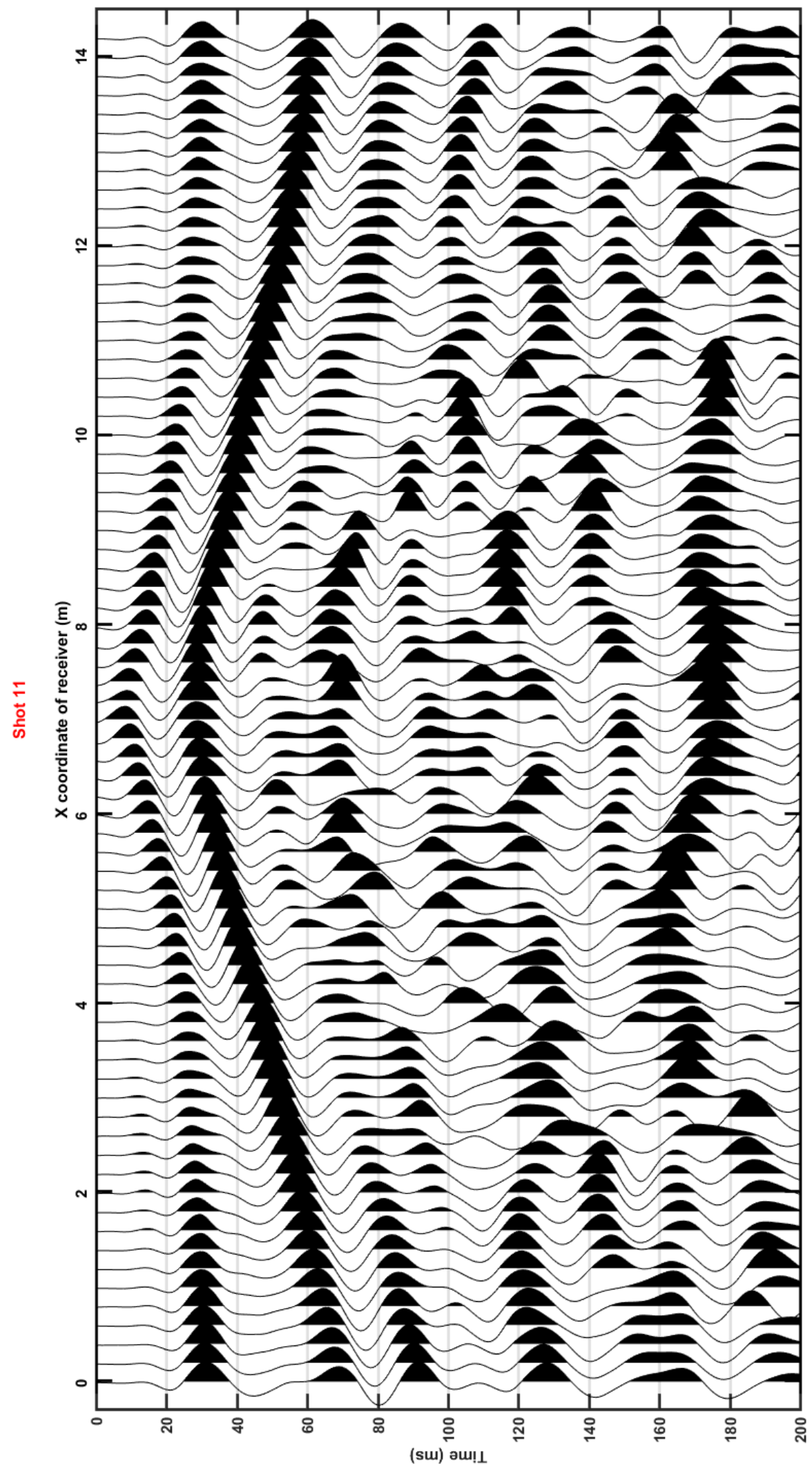




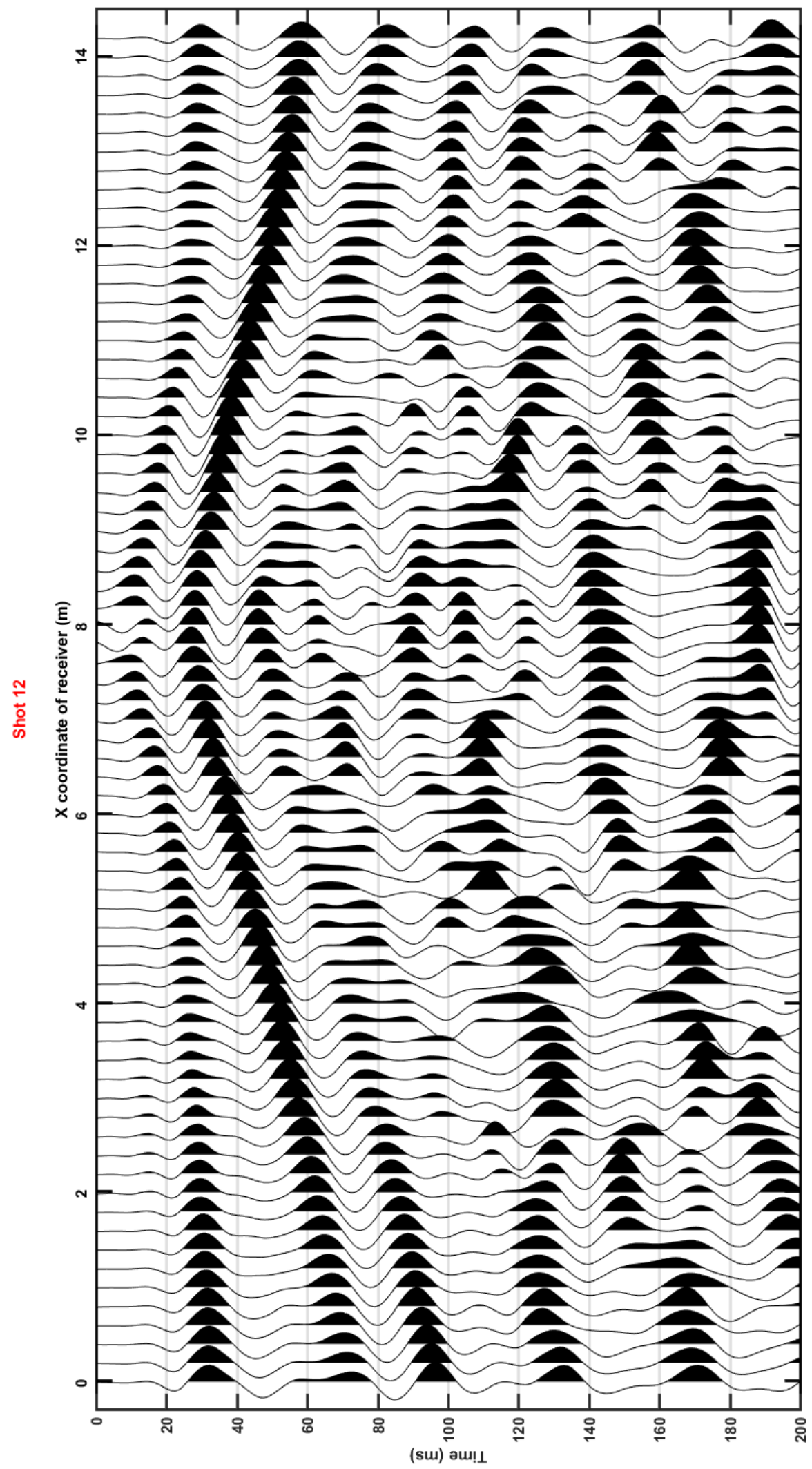




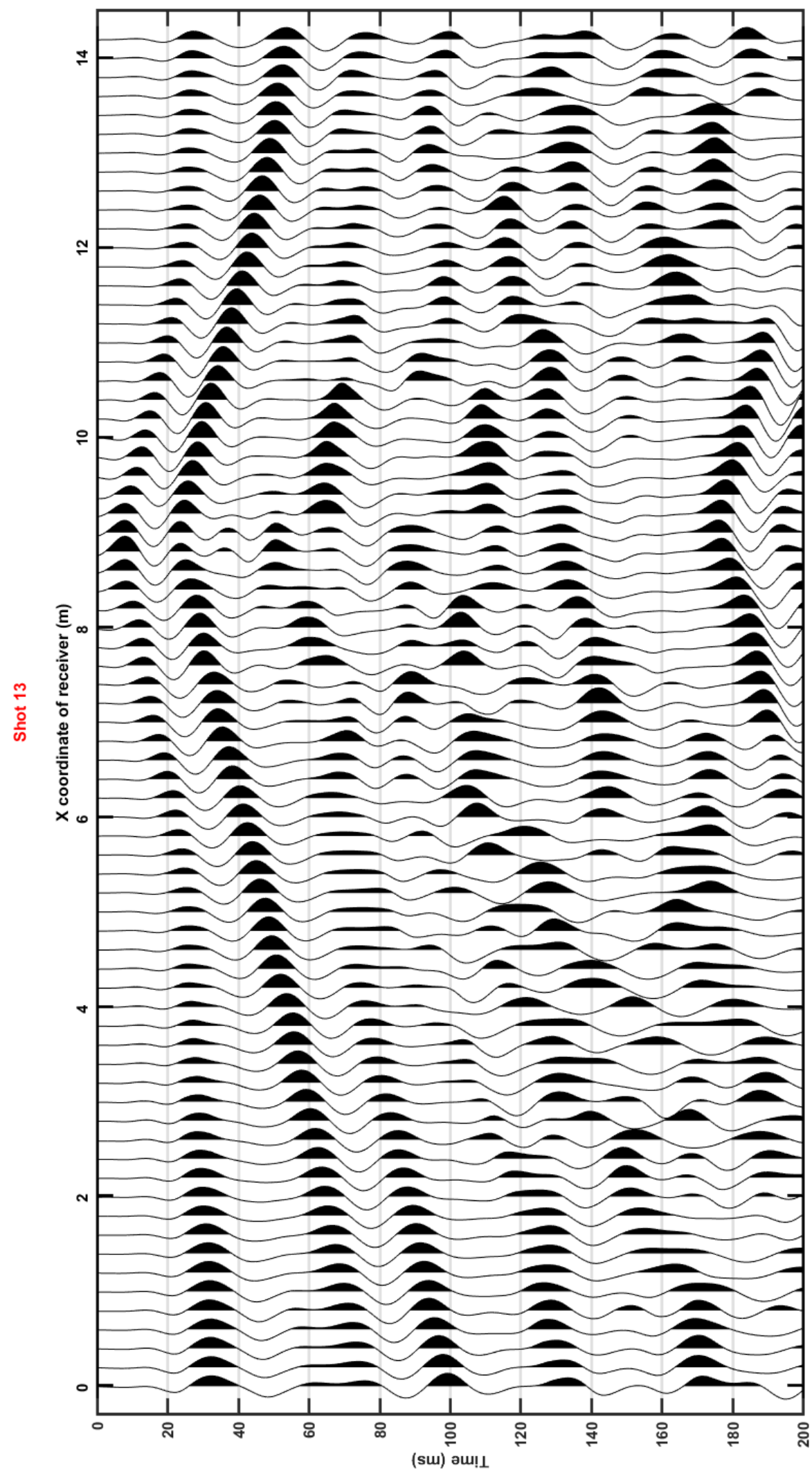




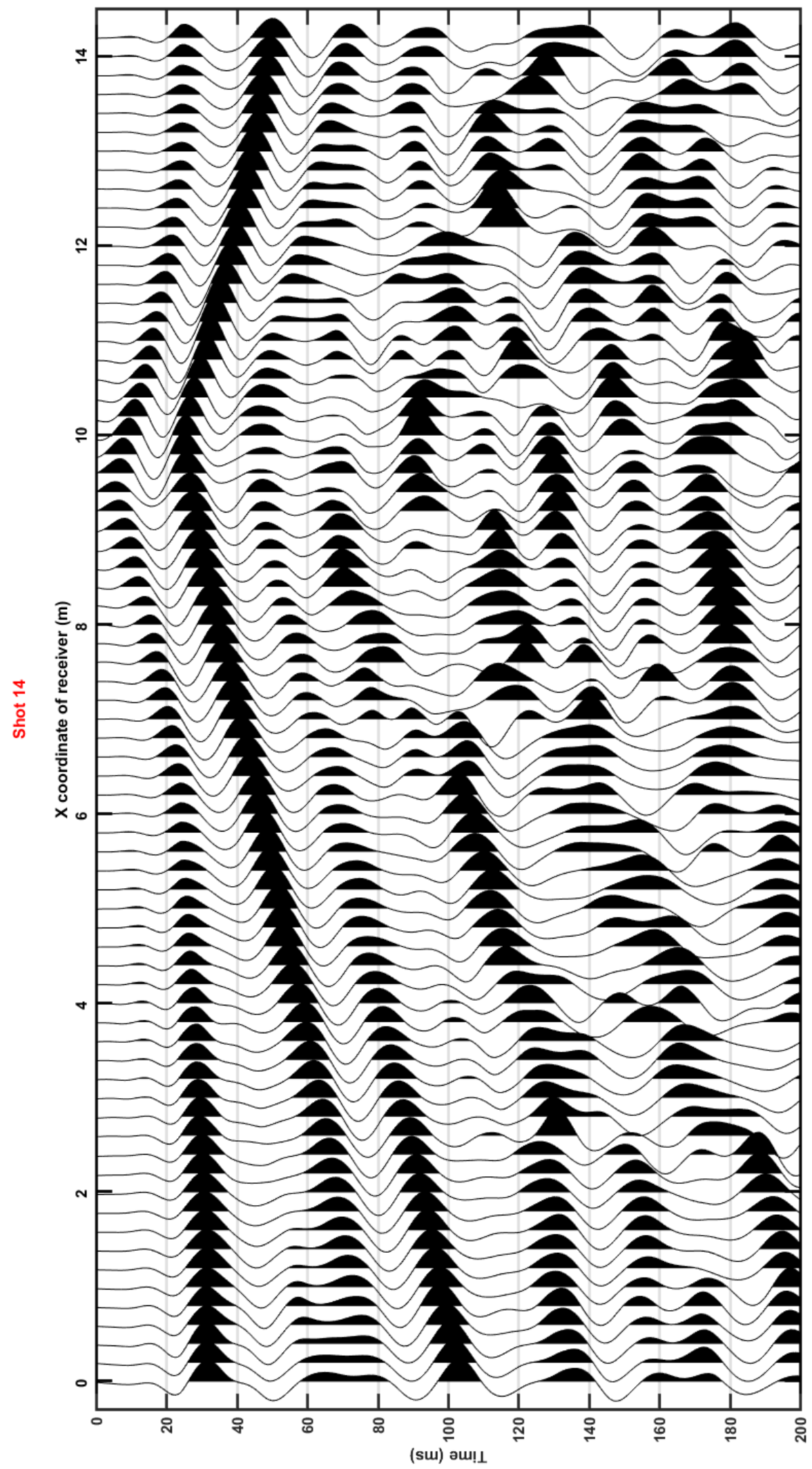




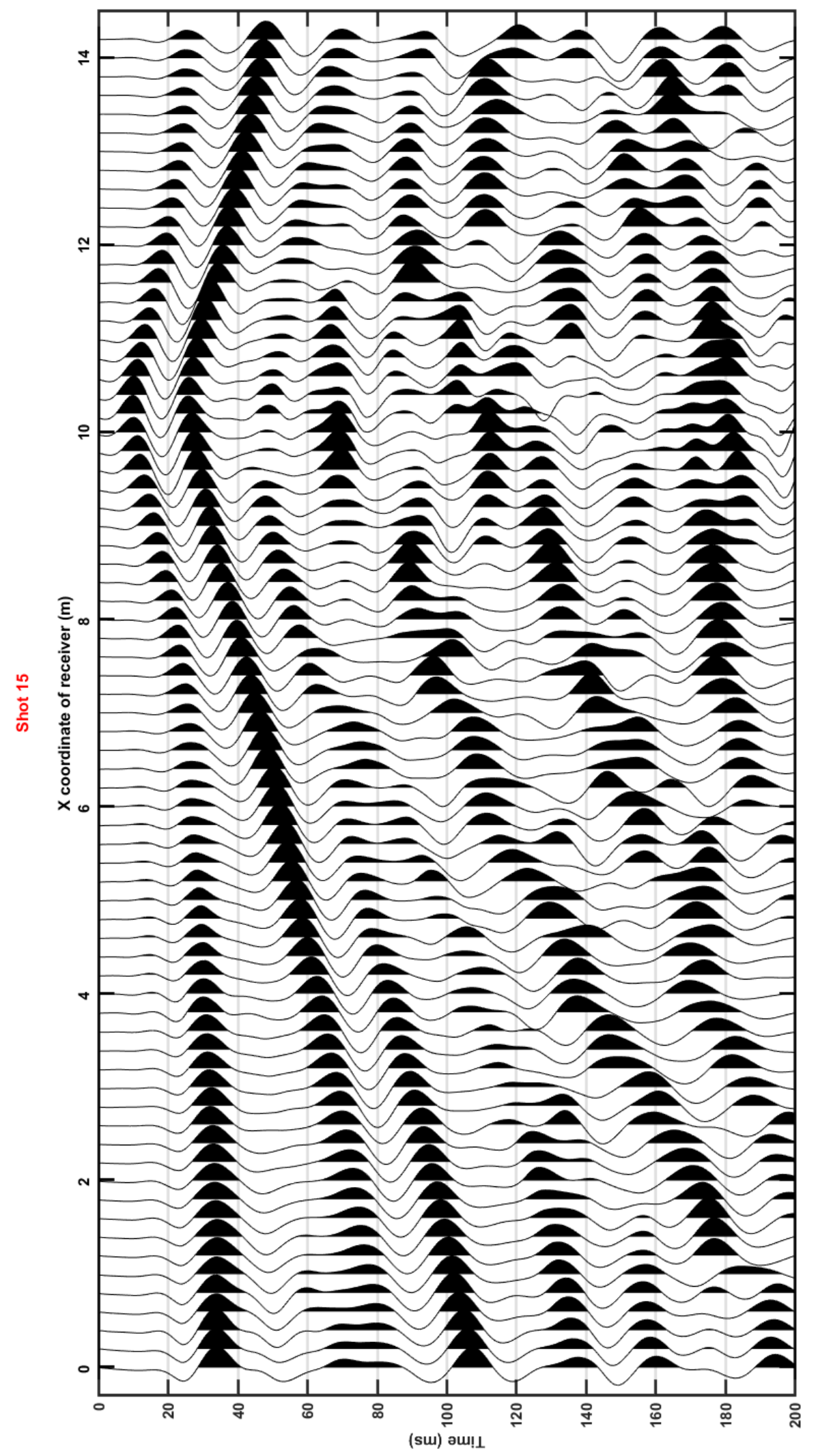




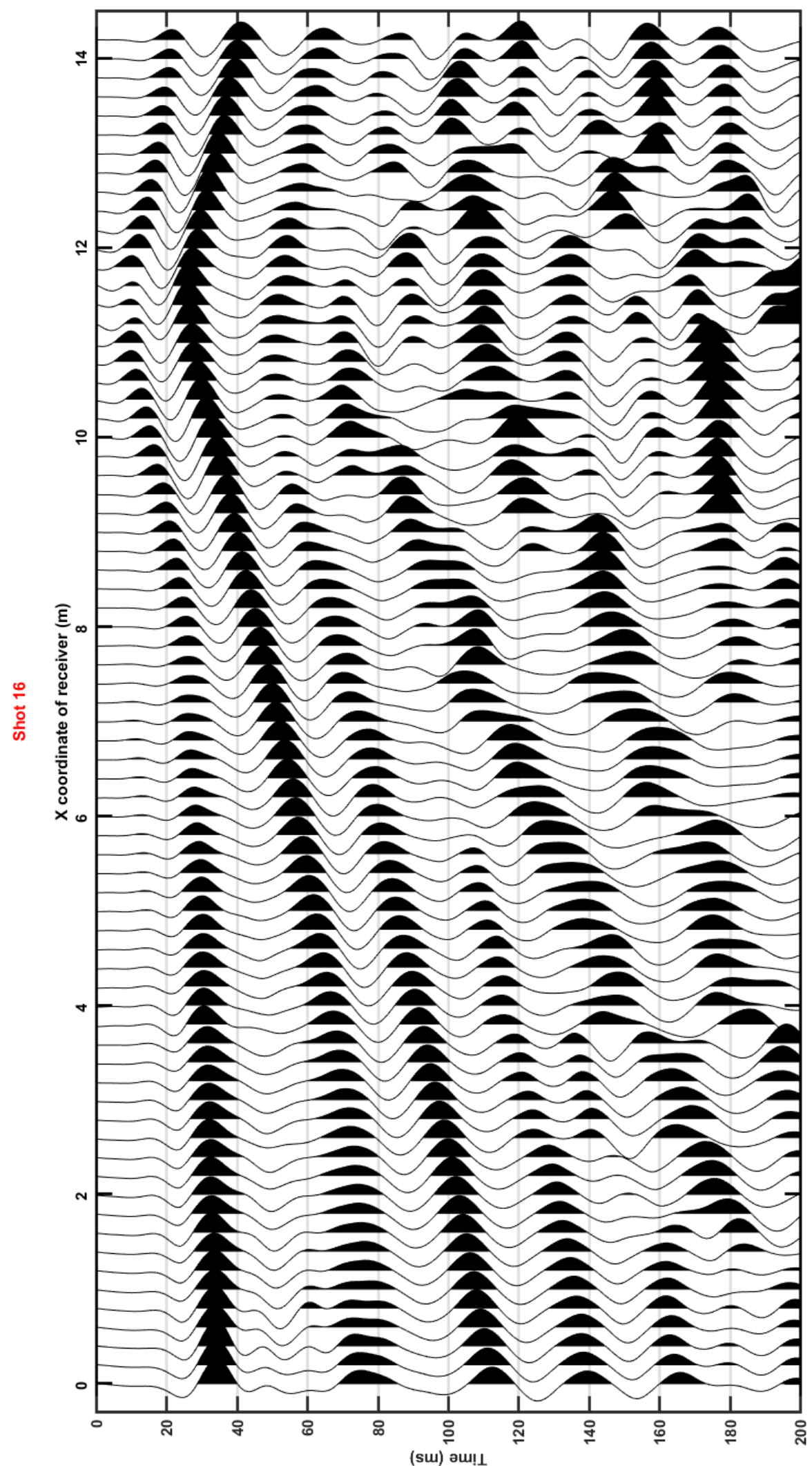

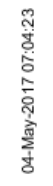




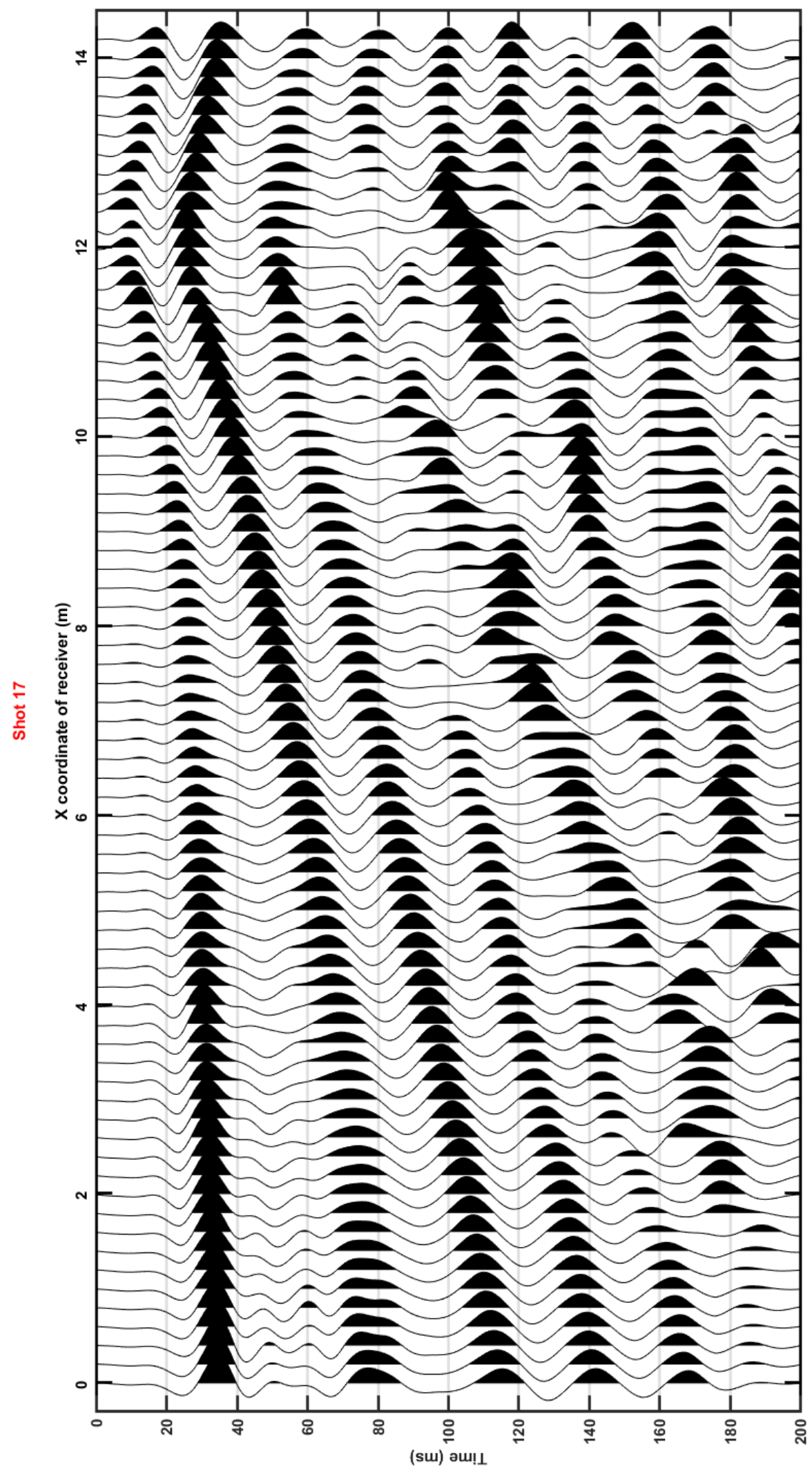




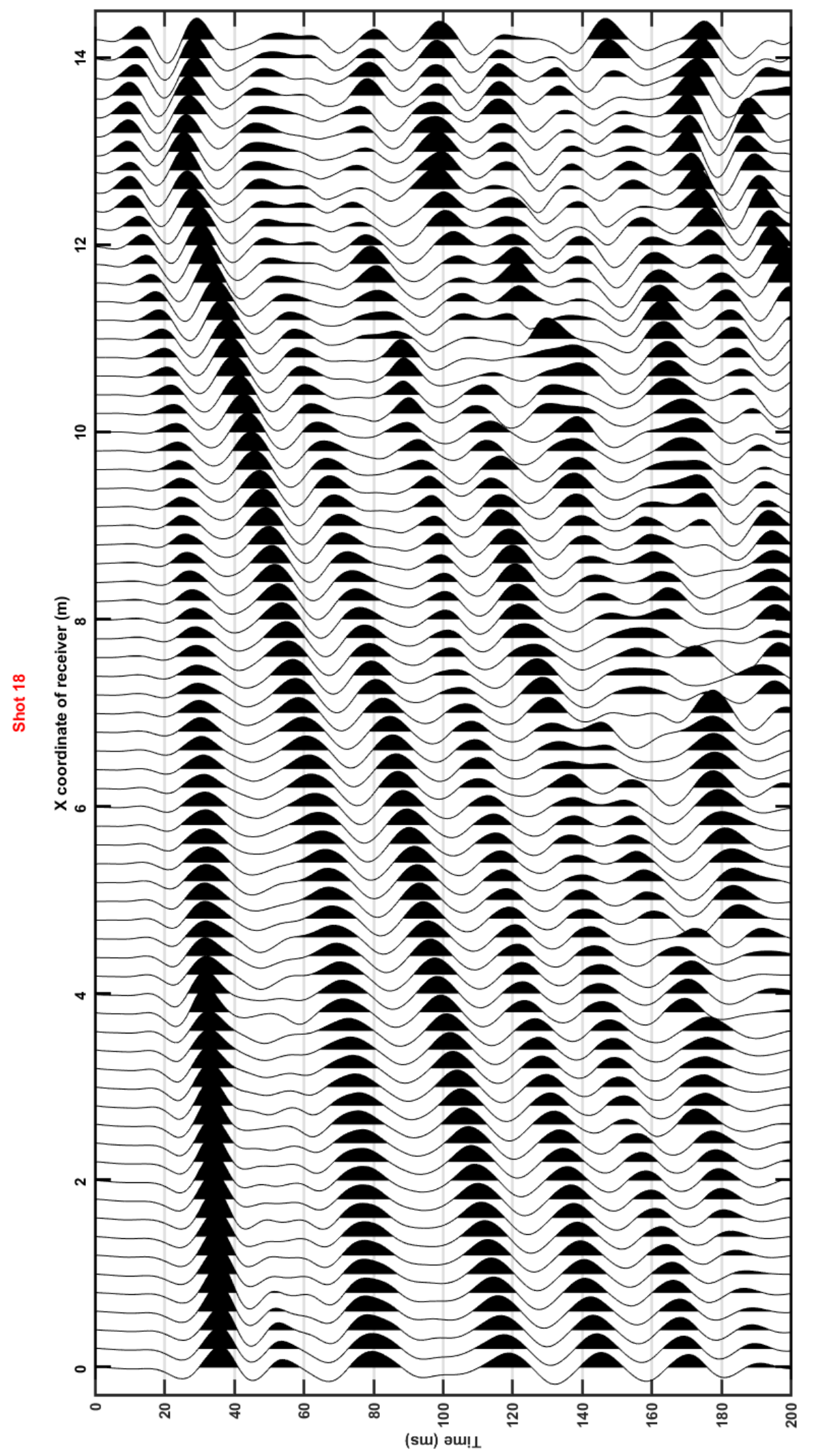




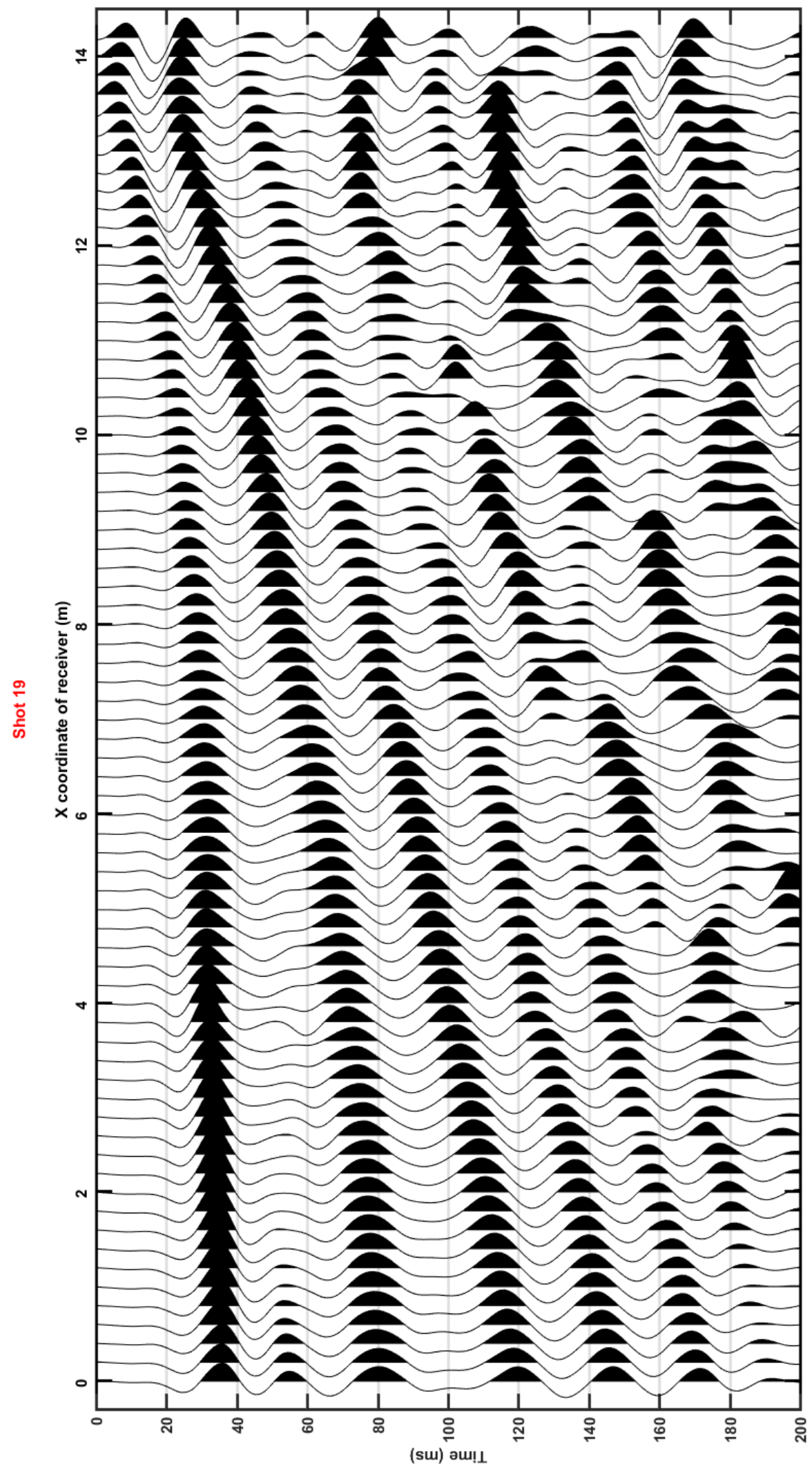




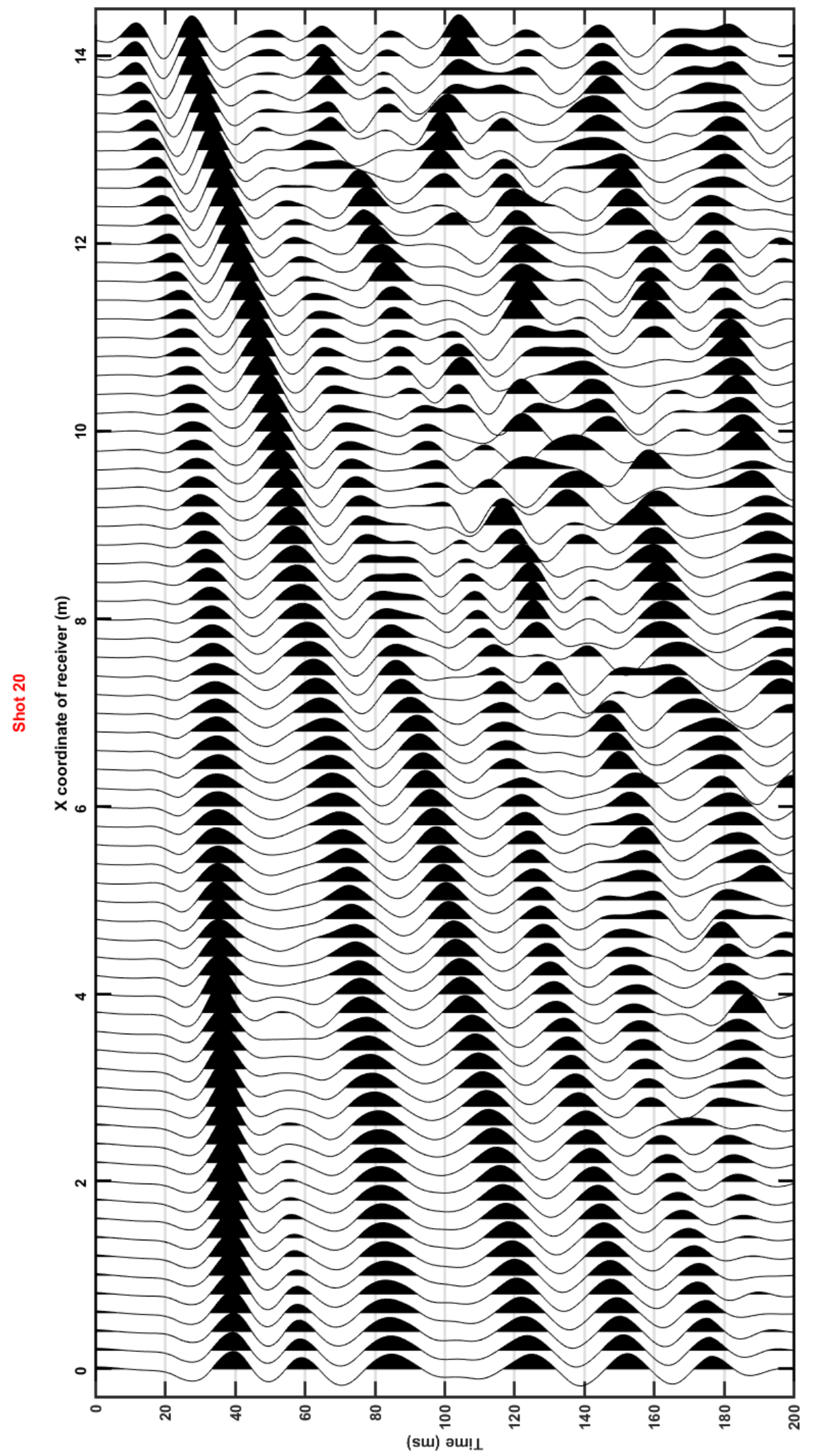




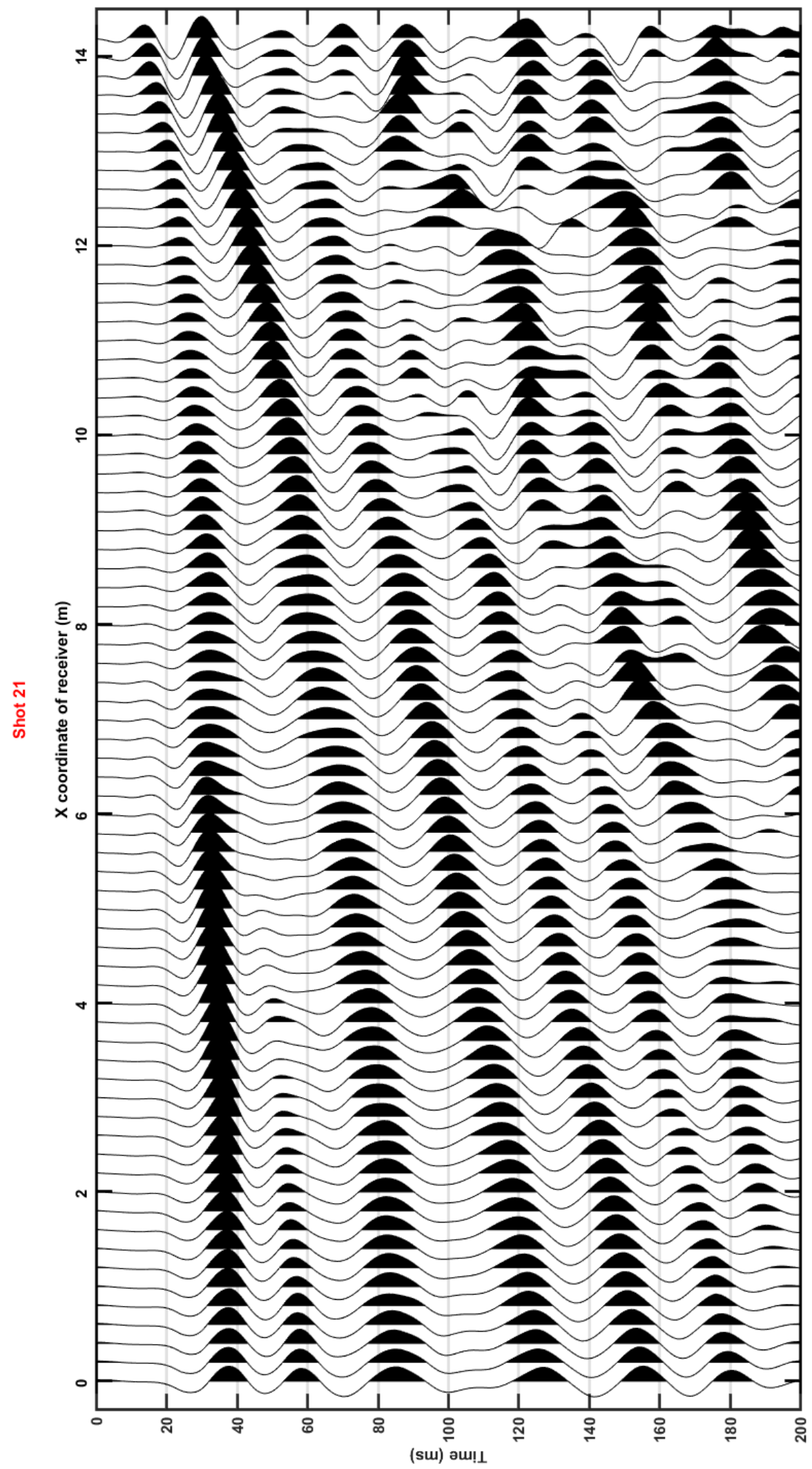




\section{Appendix F: Radiocarbon Sample Photographs}

Appendix $\mathrm{F}$ contains photographs of macrocharcoal samples taken under a binocular microscope. Only sample WM_16_RC15 yielded sufficient macrocharcoal material for radiometric analysis.
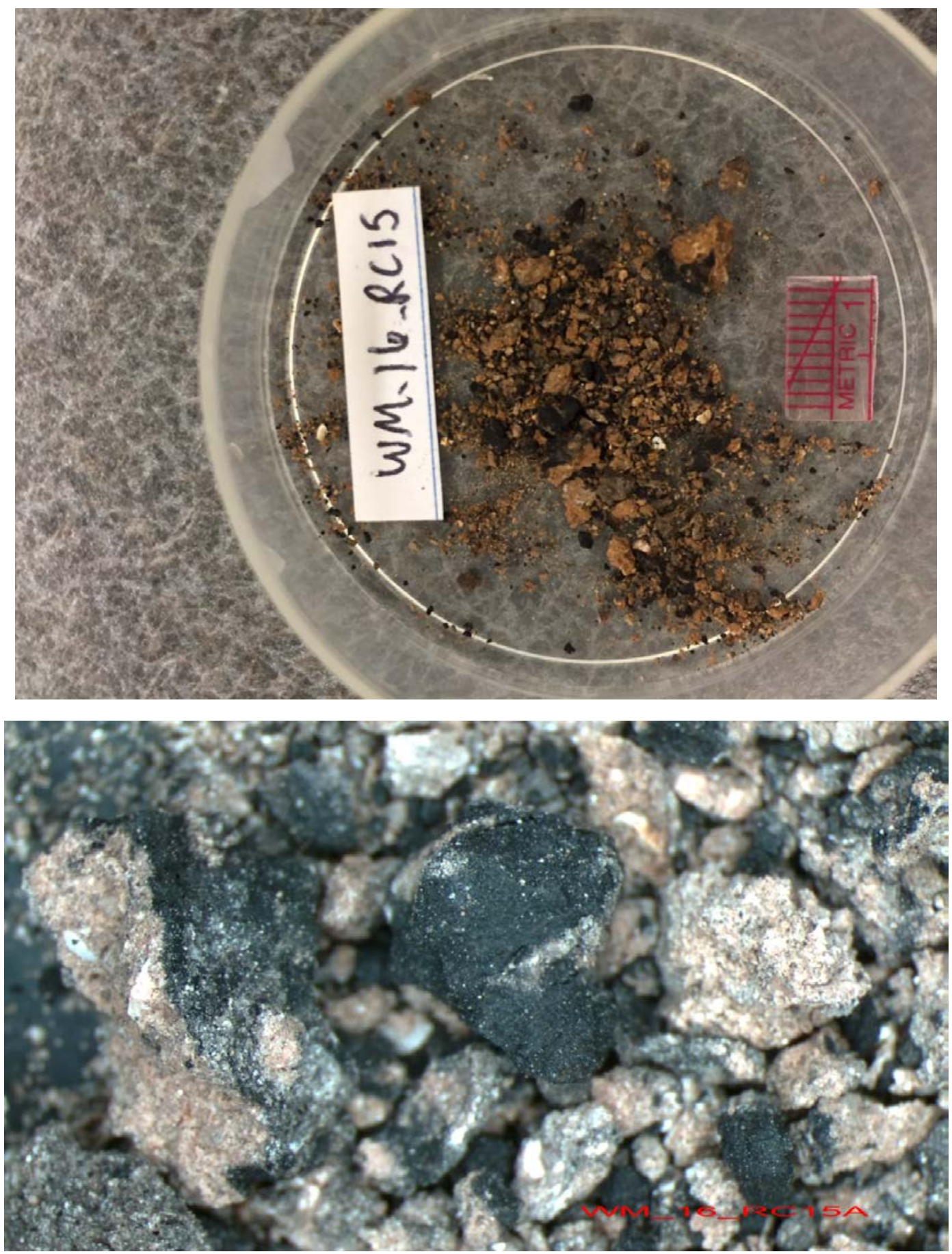